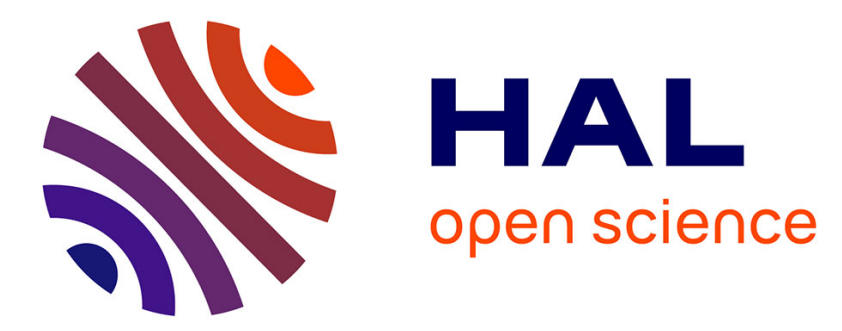

\title{
The Deep Structure of the Alps Based on the CIFALPS Seismic Experiment: A Synthesis
}

\author{
Marco Giovani Malusà, Stéphane Guillot, Liang Zhao, Anne Paul, Stefano \\ Solarino, Thierry Dumont, Stephane Schwartz, Coralie Aubert, Paola \\ Baccheschi, Elena Eva, et al.
}

\section{To cite this version:}

Marco Giovani Malusà, Stéphane Guillot, Liang Zhao, Anne Paul, Stefano Solarino, et al.. The Deep Structure of the Alps Based on the CIFALPS Seismic Experiment: A Synthesis. Geochemistry, Geophysics, Geosystems, 2021, 22 (3), pp.e2020GC009466. 10.1029/2020GC009466 . hal-03196259

\section{HAL Id: hal-03196259 \\ https://hal.science/hal-03196259}

Submitted on 12 Apr 2021

HAL is a multi-disciplinary open access archive for the deposit and dissemination of scientific research documents, whether they are published or not. The documents may come from teaching and research institutions in France or abroad, or from public or private research centers.
L'archive ouverte pluridisciplinaire HAL, est destinée au dépôt et à la diffusion de documents scientifiques de niveau recherche, publiés ou non, émanant des établissements d'enseignement et de recherche français ou étrangers, des laboratoires publics ou privés. 


\section{The Deep Structure of the Alps based on the CIFALPS Seismic Experiment: A Synthesis}

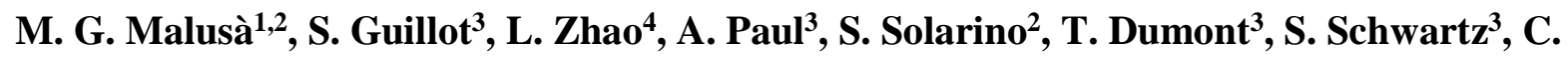
Aubert $^{3}$, P. Baccheschi ${ }^{5}$, E. Eva ${ }^{2}$, Y. Lu ${ }^{3}$, C. Lyu ${ }^{4}$, N. Piana Agostinetti6,1, S. Pondrelli5 ${ }^{5}$, S. Salimbeni ${ }^{5}$, W. Sun ${ }^{7}$ and H. Yuan ${ }^{8,9,10}$

${ }^{1}$ Department of Earth and Environmental Sciences, University of Milano-Bicocca, Milan, Italy.

${ }^{2}$ Istituto Nazionale di Geofisica e Vulcanologia, ONT, Genova, Italy.

${ }^{3}$ Univ. Grenoble Alpes, Univ. Savoie Mont Blanc, CNRS, IRD, IFSTTAR, ISTerre, 38000 Grenoble, France.

${ }^{4}$ State Key Laboratory of Lithospheric Evolution, Institute of Geology and Geophysics, Chinese Academy of Sciences, Beijing, China.

${ }^{5}$ Istituto Nazionale di Geofisica e Vulcanologia, Bologna, Italy.

${ }^{6}$ Dublin Institute for Advanced Studies, Geophysics Section, School of Cosmic Physics, Dublin, Ireland.

${ }^{7}$ Key Laboratory of Earth and Planetary Physics, Institute of Geology and Geophysics, Chinese Academy of Sciences, Beijing, China.

${ }^{8}$ ARC Centre of Excellence for Core to Crust Fluids Systems, Department of Earth and Planetary Sciences, Macquarie University, North Ryde, Australia.

${ }^{9}$ Centre for Exploration Targeting, University of Western Australia, Perth, Australia.

${ }^{10}$ Geological Survey of Western Australia, Perth Australia.

Corresponding author: Marco Giovanni Malusà (marco.malusa@unimib.it)

Key Points:

- Summary of the main results of the CIFALPS seismic experiment provides new insights on the deep tectonic structure of the Alpine region

- Application of a wide range of tomographic methods and joint interpretation with geological and petrophysical data

- Interpretive geologic cross sections at the scale of the lithosphere and the upper mantle

This article has been accepted for publication and undergone full peer review but has not been through the copyediting, typesetting, pagination and proofreading process, which may lead to differences between this version and the Version of Record. Please cite this article as doi: 10.1029/2020GC009466. 


\begin{abstract}
The European Alps are the site where classic geologic concepts such as nappe theory, continental subduction and slab breakoff have been first proposed. However, the deep tectonic structure of the Alps has long been poorly constrained by independent geophysical evidence. This review paper summarizes the main results of the CIFALPS passive seismic experiment, that was launched by Chinese, French and Italian scientists in the 2010s to provide new insights on the deep tectonic structure of the Alpine region. The application of a wide range of tomographic methods to the analysis of a single fossil subduction zone makes the CIFALPS experiment a potential reference case for the analysis of other orogenic belts. Major results include: (i) the first seismic evidence of European continental crust subducted into the Adriatic upper mantle, beneath the place where coesite was first recognized in continental (U)HP rocks in the Alps; (ii) evidence of a major involvement of the mantle wedge during (U)HP rock exhumation; (iii) evidence of a serpentinized plate interface favouring continental subduction; (iv) evidence of a continuous slab beneath the Western and Central Alps, ruling out the classic model of slab breakoff magmatism; (v) evidence of a polyphase development of anisotropic fabrics in the Alpine mantle, either representing active mantle flows or fossil fabrics inherited from previous rifting stages. Detection of these major tectonic features allows to propose interpretive geologic cross sections at the scale of the lithosphere and upper mantle, providing a baseline for future analyses of active continental margins.
\end{abstract}

\title{
Plain Language Summary
}

The European Alps are the site where classic geologic concepts such as nappe theory, continental subduction and slab breakoff have been first proposed. However, the deep tectonic structure of the Alps has long been poorly constrained by independent geophysical evidence. This review paper summarizes the main results of the CIFALPS passive seismic experiment, which allows us to propose an updated image of the deep structure of the Alps at the scale of the lithosphere and the upper mantle. The concepts and ideas summarized in this article provide a baseline for further advances in the fields of Alpine tectonics and in the analysis of active continental margins more generally.

\section{Introduction}

The European Alps are one of the best studied orogenic belts in the world, and the site where classic concepts of major relevance for the development of Earth Sciences have been first proposed. Beside the nappe theory (Lugeon 1901; Argand 1911), these include the concept of continental subduction, that was considered as impossible until the discovery of coesite in eclogitefacies rocks of the Dora-Maira massif (Chopin 1984), and the concept of slab breakoff that was first proposed by Davies and von Blanckenburg (1995) to explain the enigmatic Cenozoic magmatism in the Alps and that was subsequently applied to many other orogenic belts worldwide (Garzanti et al. 2018). Despite the relevance of these processes at a broader scale, the deep tectonic structure of the Alps has long been poorly constrained by independent geophysical evidence. The active seismic experiments launched in the 1980s (e.g., Frei et al. 1990; Nicolas et al. 1990b; Roure et al. 1996) even failed to clearly detect the Moho beneath the Internal Alps, and the travel-time tomography models available since the 2000s (e.g., Piromallo and Morelli 2003; Lippitsch et al. 2003) did provide first-order constraints to the deep Alpine structure although they were not invariably consistent.

This article is protected by copyright. All rights reserved. 
Within this framework, the aim of the CIFALPS passive seismic experiment, launched in the 2010s through a collaboration among Chinese, French and Italian scientists (Zhao et al. 2016a) was to provide new insights on the deep tectonic structure of the Alpine region, based on recent developments in the fields of seismic data acquisition and tomography model computation, through a full collaboration between geologists and geophysicists. The main geophysical results provided by the CIFALPS experiment have been already published in international journals (Zhao et al. 2015,2016a, 2020; Lyu et al. 2017; Malusà et al. 2017; Beller et al. 2018; Salimbeni et al. 2018; Solarino et al. 2010; Sun et al. 2019). In this review paper, mainly aimed at a geologic audience, we summarize the main results of the CIFALPS experiment that are discussed within the framework of available geologic and geodynamic constraints to provide an updated image of the deep structure of the Alps at the scale of the lithosphere and the upper mantle. We hope that the concepts and ideas summarized in this article will help provide a baseline for further advances in the fields of Alpine tectonics and in the analysis of active continental margins more generally.

\section{Tectonic setting}

The European Alps are the result of oblique subduction of the Alpine Tethys under the Adriatic microplate since the Late Cretaceous, followed by diachronous continental collision between the Adriatic and European paleomargins during the Cenozoic (e.g., Trümpy 1960; Coward and Dietrich 1989; Dal Piaz 2001; Schmid et al. 2004; Handy et al. 2010; Pfiffner 2014) (Fig. 1a). In the western segment of the orogen, European basement rocks and associated HelveticDauphinois cover sequences that have partly escaped Alpine metamorphism are exposed in the External zone, to the west of the Frontal Pennine Fault (FPF in Fig. 1b) (e.g., Dumont et al. 2011, 2012; Bellahsen et al. 2014). To the east of the Frontal Pennine Fault, the subduction wedge formed atop the European slab is still largely preserved (e.g., Lardeaux et al. 2006; Beltrando et al. 2010) and chiefly includes rocks derived from the Alpine Tethys and the distal European paleomargin (Tricart 1984; Lemoine et al. 1986), the so-called Penninic units (Argand 1911) (shades of blue in Fig. 1b). Rocks derived from the Adriatic paleomargin (brown in Fig. 1b), classically referred to as the Austroalpine-Southalpine units (e.g., Bernoulli et al. 1979; Mohn et al. 2010), are exposed north of the Po Plain on the upper-plate side of the orogen. There, the Ivrea gravity anomaly (Closs and Labrouste 1963) reveals the occurrence of mantle rocks exhumed at shallow depth that may mark the lithospheric necking zone of the southern Tethyan margin (Nicolas et al. 1990a). Eclogitized mantle rocks are exposed in the Lanzo massif to the west of the Insubric Fault (IF in Fig. 1b) (Boudier 1978; Piccardo et al. 2007). South of the Po Plain, the complex transition zone between the Western Alps and the Apennines involves rotated fragments of the Alpine subduction wedge (Maffione et al. 2008; Eva et al. 2015) and is mainly covered by thick Cenozoic sedimentary successions (Rossi et al. 2009; Malusà and Balestrieri 2012).

The subduction wedge of the Western Alps includes two main tectono-metamorphic domains (e.g., Malusà et al. 2011, 2015): (i) an Eocene eclogite belt consisting of (ultra) high pressure - (U)HP continental crust domes of European derivation (DM, GP and MR in Fig. 1b) (e.g., Dal Piaz and Lombardo 1986; Henry et al. 1993) tectonically enveloped by (U)HP metaophiolites (e.g., Lombardo et al. 1978; Schwartz et al. 2000); and (ii) a doubly-vergent Frontal wedge consisting of lower-pressure metamorphic units exposed closer to the European mainland (e.g., Caby 1996; Michard et al. 2004). The (U)HP rocks of the Eclogite belt reached the pressure peak in the late Eocene (e.g., Rubatto and Hermann 2001; Gabudianu Radulescu et al. 2009) and were rapidly exhumed to Earth's surface by the early Oligocene, when they were unconformably

This article is protected by copyright. All rights reserved. 
covered by syntectonic sediments still preserved in the Tertiary Piedmont Basin (Federico et al. 2004; Malusà et al. 2015) (Fig. 1b). Quartz-eclogite assemblages prevail, but rock slivers with coesite-eclogite assemblages are found in the Dora-Maira dome (Chopin et al. 1991; Groppo et al. 2019) and on top of the Monte Rosa dome (Reinecke 1991; Lapen et al. 2003). The lower-pressure metamorphic units of the Frontal wedge include blueschist-to-(sub)greenschist facies cover sequences and basement slivers that underwent subduction starting from the Paleocene, and were later exhumed in the Eocene - early Oligocene (e.g., Agard et al., 2002; Ganne et al. 2007; Lanari et al. 2014). Different tectonostratigraphic domains are exposed in different segments of the Frontal wedge, likely reflecting the obliquity of the Alpine trench relative to the European paleomargin. In the northern part of the Western Alps, the Frontal wedge includes Valaisan metasediments with minor metaophiolites and upper Paleozoic continental metaclastics (Bertrand et al. 1998; Masson et al. 2008; Polino et al. 2012), juxtaposed against Briançonnais (Br in Fig. 1b) basement units in the rear part of the wedge (Malusà et al. 2005; Bergomi et al. 2017). In the southern part of the Western Alps, the Frontal wedge includes turbidites and Briançonnais cover sequences (Kerckhove 1969; Barfety et al. 1996) juxtaposed against the oceanic metasediments of the Schistes lustrés (SL in Fig. 1b) (Polino and Lemoine 1984; Agard et al. 2002; Schwartz et al. 2009). Progressively more distal facies are thus accreted in the Frontal wedge moving from the North toward the South, but the effects of oblique subduction are also observed in the Eclogite belt, where the relative amount of oceanic crust comprised within the eclogitic tectonic domes increases towards the south and is dominant in the Voltri massif (Forcella et al. 1973; Capponi and Crispini 2002). The well preserved domal shape of the Dora-Maira and Gran Paradiso massifs (Fig. 1b) suggests only minor late-stage indentation of the Adriatic upper plate beneath the southern segments of the Alpine subduction wedge, whereas farther north the Monte Rosa dome is evidently backfolded (Keller et al. 2005), and the Adriatic lower crust has been deeply indented beneath the Lepontine dome during the latest stages of hard continent-continent collision (Pfiffner et al. 2002; Liao et al. 2018a).

\section{State of knowledge before the CIFALPS experiment}

Since the pioneering studies of Dolomieu (1791), Kilian and Revil (1903), Lugeon (1901, 1902) and Argand (1911, 1916), the reconstruction of the deep tectonic structure of the Alps has long been based on field geology data, including the vergence of regional folds (e.g., Ramsay 1963; Milnes 1974) and the polarity of metamorphic field gradients (e.g., Ernst 1971, 1973). Following this approach, the occurrence of higher-pressure rocks towards the Po Plain (e.g., Bocquet 1971; Frey et al. 1974) and the first radiometric constraints to the age of Alpine metamorphism (e.g., Ferrara et al. 1962; Bocquet et al. 1974) have generally suggested an Alpine evolution driven by European subduction beneath Adria, and a progressive deformation propagation towards the European foreland (e.g., Martini 1972; Dewey et al. 1973; Laubscher 1974; Hawkesworth et al. 1975). However, based on the same data sets, alternative interpretations invoking Adriatic subduction were also proposed (e.g., Oxburg 1972; Caby 1975).

Starting from the 1980s, independent constraints to the deep structure of the Alps were provided by active seismic experiments launched in the Western and the Central Alps. They include the joint French-Italian ECORS-CROP experiment across the northern Western Alps (Nicolas et al. 1990b; Roure et al. 1996) and the NFP-20 research program in the Swiss Alps (Frei et al. 1990) (see locations in Fig. 1b). The ECORS-CROP vertical seismic reflection profile (Fig. 2a) has successfully imaged the SE-dipping European lower crust beneath the European foreland (ELC in Fig. 2a), the SE-dipping Frontal Pennine Fault (FPF in Fig. 2a), the top of the Adriatic

This article is protected by copyright. All rights reserved. 
mantle beneath the Ivrea gravity anomaly (AM in Fig. 2a) and the Po Plain basin fill (Nicolas et al. 1990b). However, it failed to image the European Moho beneath the Alpine subduction wedge, as underlined by the question mark in Fig. 2a. Additional constraints indicating European subduction beneath Adria were anyway provided by a complementary wide-angle reflection profile (Thouvenot et al. 1990) showing SE-dipping Moho-like surfaces beneath the frontal part of the Alpine metamorphic wedge and beneath the Gran Paradiso dome (Fig. 2b). A migrated ECORS-CROP vertical seismic reflection profile (Fig. 2c) was later reinterpreted by Schmid and Kissling (2000), who suggested that the strong reflectors at $\sim 20 \mathrm{~km}$ depth beneath the Gran Paradiso would mark the top of a slice of European lower crust (ELC in Fig. 2c), rather than the top of a mantle slice as originally proposed by Nicolas et al. (1990a) and Polino et al. (1990) (Fig. 2a). According to Schmid and Kissling (2000), the reflectors located at 10-15 km depth beneath the Gran Paradiso would mark the suture zone of the Valaisan ocean, a controversial paleogeographic feature (e.g, Stampfli et al. 2002; Masson et al. 2008) potentially documented only in the Central Alps and in the northernmost Western Alps (Liati and Froitzheim 2006). Information provided by the NFP-20 West profile (Frei et al. 1990) is even more limited. In fact, this profile (in green in Fig. 1b) is limited to the frontal part of the Alpine subduction wedge and to the nearby External zone. The classic geologic cross sections proposed by Schmid et al. (2004) along the ECORS-CROP and NFP-20 traverses, which are shown in Figs. $2 \mathrm{~d}$ and $2 \mathrm{f}$, are thus constrained only to a limited extent by geophysical data (the masked areas in Figs. $2 \mathrm{~d}$ and $2 \mathrm{f}$ indicate regions not constrained by vertical reflection seismic data). In the absence of further independent constraints, these cross sections have reproduced the nappe structure proposed by Argand (1911) (Fig. 2e), which was conceived well before the advent of plate tectonics.

Since the late 1990s, independent geophysical constraints on the deep Alpine structure were also provided for the southern Western Alps (Tardy et al. 1999) thanks to the GeoFrance 3D project (Groupe de Recherche Géofrance 3D 1997). A local earthquake tomography model (Paul et al. 2001) was able to resolve the deep tectonic structure beneath the Dora-Maira down to depths of $15-20 \mathrm{~km}$ (Fig. $2 \mathrm{~g}$ ), leading to the detection of mantle rocks at depths as shallow as $\sim 10 \mathrm{~km}$ (AM in Fig. 2g) and to a geologic interpretation (Lardeaux et al. 2006) that was still largely based on field geology data (right panel in Fig. 2g). Geologic cross sections of the southern Western Alps were also presented by Schmid et al. (2017), who suggested an East-vergent backfold at the scale of the entire Eclogite belt and the occurrence, beneath the Dora-Maira massif, of Briançonnais crust slivers down to depths $>30 \mathrm{~km}$ (see Schmid et al. 2017, their Fig. 2). However, the DoraMaira dome shows no cartographic evidence for such a backfold (Figs. 1b, 2g), and the Schmid et al. (2017)'s interpretation was not consistent with seismic velocity constraints provided by the GeoFrance 3D experiment (Paul et al. 2001).

Starting from the 2000s, travel-time tomography studies (e.g., Piromallo and Morelli 2003; Lippitsch et al. 2003; Giacomuzzi et al. 2011) have provided further constraints on the deep structure of the Alpine region, revealing high-velocity anomalies in the Alpine upper mantle (Fig. $3 \mathrm{a}, \mathrm{b})$ that were readily interpreted as traces of subducting slabs (e.g., Piromallo and Faccenna 2004; Spakman and Wortel 2004; Kissling et al. 2006). However, some of these models showed high-velocity anomalies in areas where no slab was expected based on geologic evidence (e.g., the Provençal margin of SE France, see Fig. 3a), and different models were not invariably consistent. For example, Piromallo and Morelli (2003) imaged a continuous high-velocity anomaly beneath the Western Alps (cross section A-A' in Fig. 3a) at the very same location where Lippitsch et al. (2003) proposed a shallow slab breakoff (cross section C-C' in Fig. 3b). The identification of a possibly missing section of the Alpine slab beneath the Central Alps (B-B' and D-D' in Fig. 3)

This article is protected by copyright. All rights reserved. 
was held to be supportive of the slab-breakoff model first proposed by Davies and von Blanckenburg (1995), which was conceived to explain Alpine magmatism and exhumation of high-pressure rocks. Despite geophysical evidence was not unequivocal, the slab-breakoff model has been applied to the Alps by several studies since then (Fig. 3c). However, unlike the original formulation of von Blanckenburg and Davies (1995) who suggested an Eocene slab breakoff (Fig. 3c), most subsequent authors have either proposed an Oligocene slab breakoff (e.g., Schmid et al. 1996; Bistacchi et al. 2001; Schlunegger and Kissling 2015; Schlunegger and Castelltort 2016) or an even younger Pliocene-Quaternary breakoff event (e.g., Sue et al. 1999; Fox et al. 2015; Kästle et al. 2020), even though no orogenic magmatism and no exhumation event occurred at that time in the Alps.

\section{The CIFALPS experiment}

The CIFALPS experiment (Zhao et al. 2016a) is the first passive seismic survey that crosscuts the entire Western Alps across the Dora Maira massif. It involves scientists and institutions from China, Italy and France. Geophysicists and geologists have worked side by side during the project, starting from the early steps of the experiment set up to the final steps of geologic interpretation. The temporary seismic network includes 46 broadband seismic stations operating from July 2012 to September 2013, deployed along a linear WSW-ESE transect from the European foreland to the western Po Plain, and 9 additional stations installed to the north and to the south of the main profile (red yellow-filled dots in Fig. 1b). Stations located along the main profile, which was chiefly conceived for receiver function analysis (Zhao et al. 2015), have spacing ranging from $\sim 5 \mathrm{~km}$ in the Alpine mountain range to $\sim 10 \mathrm{~km}$ in the European foreland and the western Po Plain. Off-profile stations were installed to improve the crossing of seismic rays for local earthquake tomography (Solarino et al. 2018) and to build mini-arrays for surface wave tomography (Lyu et al. 2017). Some of the analyses performed during the CIFALPS experiment (e.g., Zhao et al. 2016b, 2020; Lyu et al. 2017; Sun et al. 2019) also exploited data sets from permanent broadband networks and benefitted from the recent opening of the European seismic databases. A dataset of anomalously deep earthquakes (purple circles in Fig. 1b) recorded in the western Po Plain during the past 25 years (Eva et al. 2015) was extremely useful to extend local earthquake tomography analysis towards greater depths and analyze the seismic anisotropy in the crust and the lithospheric mantle.

Most of the analyses presented in this summary work have been published in international journals. The reader is referred to the original publications (see Table 1) for a more detailed discussion of the procedures followed for the different types of tomography models and for an estimate of their resolution. Different tomographic methods allow to illuminate different levels of the crust and the mantle, and at different locations with respect to the Alpine slab (Table 1). It should be remembered that a tomographic model is not a true image of the Earth subsurface. It shows the projection of a data set onto a model space controlled by simplifying assumptions. Its accuracy is limited by the seismic data availability and quality, the type of wave used, and the assumptions made. Moreover, solutions are not unique. For example, in teleseismic body wave tomography the ray geometry tends to induce vertical smearing, whereas in surface wave tomography the accuracy of the model degrades with depth. Imaging the Alpine subduction system requires the integration of different tomographic methods through interpretive steps that should avoid any over-interpretations of observed features. A close collaboration between geophysicists and geologists is thus particularly important. The series of independent tomographies presented in this summary paper, despite their numerous limitations, converge towards a coherent geologic

This article is protected by copyright. All rights reserved. 
model, which attests to the robustness of our geologic interpretation of the deep structure of the Alps. The application of a wide range of tomographic methods to the analysis of a single fossil subduction zone (Table 1) makes the CIFALPS experiment a reference case that could be exported to other orogenic belts.

\section{Seismic velocities of rocks involved in the Alpine orogeny}

The geologic interpretation of geophysical information provided by the CIFALPS experiment requires independent knowledge of seismic velocities of rocks possibly involved in the Alpine subduction zone. Various proportions of serpentinized mantle, basalts and sedimentary rocks were subducted at the Alpine trench since the Cretaceous during the oceanic subduction stage (Dal Piaz and Ernst 1978; Deville et al. 1992; Agard et al. 2009; Guillot et al. 2009a). Due to the low spreading rates characterizing the Alpine Tethys in the Jurassic, exhumed mantle rocks were dominant on the Tethys seafloor compared to pillow basalts (Lagabrielle and Cannat 1990; Lagabrielle and Lemoine 1997; Manatschal 2004; Piccardo 2003). Rocks from the Tethys seafloor were initially subducted together with slivers of granitic and (meta)sedimentary rocks from the hyperextended Adriatic paleomargin (Rubatto et al. 1998; Thöni 2006; Zanchetta et al. 2012), whereas granitic and (meta)sedimentary rocks from the European paleomargin were later involved in the subduction zone during the main stage of continental subduction in the Paleogene (Rubatto and Hermann 2001; Malusà et al. 2011; Lanari et al. 2012).

P-wave and S-wave velocities for all of these lithologies are provided by several laboratory experiments (e.g., Bezacier et al. 2010, 2013; Ji et al. 2013, 2015; Kern et al. 2002; Khazanehdari et al. 2000; Pera et al. 2003; Reynard 2013; Rudnick and Fountain 1995; Watanabe et al. 2011; Weiss et al. 1999) and are summarized in the diagrams of Fig. 4. The ellipse size in these diagrams is proportional to the maximum and minimum seismic velocities. The ellipse location depends on the pressure-temperature range at equilibrium for each rock type. As shown in Fig. 4, for a given bulk composition, rocks generally display a progressive increase in $\mathrm{P}$ and $\mathrm{S}$ velocities with depth (i.e., pressure) and metamorphic grade (i.e., temperature). For a specific rock type, the effects of increasing pressure with depth, which would imply an increase in seismic velocity, are partly compensated by the effects of increasing temperature that would conversely imply a seismic velocity decrease. As a result, for a given bulk composition (indicated by ellipses of the same color) major changes in $\mathrm{Vp}$ and $\mathrm{Vs}$ are mainly due to changes in metamorphic mineral assemblages with depth. For example, Vp values in metapelites (brown in Fig. 4) progressively increase, according to laboratory experiments from $5.6-6.4 \mathrm{~km} \mathrm{~s}^{-1}$ in low-grade metapelites to $6.5-6.7 \mathrm{~km} \mathrm{~s}^{-}$ ${ }^{1}$ in medium-grade metapelites, reaching values as high as $7.2 \mathrm{~km} \mathrm{~s}^{-1}$ in high-grade metapelites with minor variability depending on rock composition (Ji et al. 2015; Khazanehdari et al. 2000; Weiss et al. 1999). In the same rocks, Vs values progressively increase from $3.3-3.8 \mathrm{~km} \mathrm{~s}^{-1}$ in lowgrade metapelites (Ji et al. 2015) to 3.8-4.1 $\mathrm{km} \mathrm{s}^{-1}$ in high-grade metapelites (Khazanehdari et al. 2000; Weiss et al. 1999). A similar progressive increase in seismic velocity with depth is also observed in mafic (blue in Fig. 4) and granitic (purple in Fig. 4) rocks.

In fully hydrated ultramafic rocks (green in Fig. 4), measured Vp values increase from 4.5-6.0 $\mathrm{km} \mathrm{s}^{-1}$ in low-temperature lizardite serpentinite to $6.3-7.0 \mathrm{~km} \mathrm{~s}^{-1}$ in high-temperature antigorite serpentinite (Bezacier et al. 2013; Ji et al. 2013). In the same rocks, Vs values increase from 2.4$3.0 \mathrm{~km} \mathrm{~s}^{-1}$ in lizardite serpentinite to $3.4-3.8 \mathrm{~km} \mathrm{~s}^{-1}$ in antigorite serpentinite, but Vs as low as 3.2 $\mathrm{km} \mathrm{s}^{-1}$ can be observed in antigorite mylonites (Watanabe et al. 2011). A sharp change in seismic velocities towards values that are typical of peridotite $\left(\mathrm{Vp}=7.7-9.0 \mathrm{~km} \mathrm{~s}^{-1}, \mathrm{Vs}=4.4-5.1 \mathrm{~km} \mathrm{~s}^{-1}\right)$

This article is protected by copyright. All rights reserved. 
(Bezacier et al. 2010; Khazanehdari et al. 2000; Pera et al. 2003) is expected across the antigoriteout curve (Hilairet et al. 2006). In partly serpentinized peridotites (inset of Fig. 4), Vp values linearly increase for decreasing volume fractions of antigorite (Reynard 2013). Correlation between seismic velocities and lithology is particularly challenging in subduction wedges, former subduction channels and the nearby upper mantle, because subducted rocks are generally heterogeneous and display anisotropic fabrics and velocity variations as a function of direction (e.g., Bezacier et al. 2013; Rudnick and Fountain 1995; Weiss et al. 1999), and Vs values are strongly reduced in the presence of fractures, fluids or partial melts. As demonstrated by laboratory studies (e.g., Yoshino et al. 2007), if melt completely wets grain boundaries, even a small amount of melt (e.g., 1\%) can produce remarkable velocity drops of 20-30\% (Karato 2010; Malusà et al. 2018).

\section{Seismic evidence of continental subduction in the Western Alps}

\subsection{Moho imaging by receiver function analysis}

The first output of the CIFALPS experiment (Zhao et al. 2015) is based on the application of the receiver function (RF) technique (Fig. 5). The RF technique exploits the P-to-S (Ps) conversion of seismic waves at velocity interfaces beneath an array of seismic stations (Langston 1979; Ligorría and Ammon 1999). It allows detection of interfaces with downward velocity increase, for example the Moho, and interfaces with downward velocity decrease possibly expected within a subduction wedge, because the polarity of the converted signal depends on the sign of the velocity change. In the Western Alps, application of the RF approach to teleseismic earthquakes (Zhao et al. 2015) has provided the first seismic evidence of European crust subducted into the Adriatic upper mantle, right beneath the place where coesite was first recognized in continental (U)HP rocks by Chopin (1984).

The RF image of Fig. 5a is based on teleseismic events with ENE back-azimuths and magnitude $\mathrm{Mw} \geq 5.5$ (the location of events is shown in Fig. 5c). In order to produce a depth image beneath the CIFALPS transect, Zhao et al. (2015) migrated the time data to depth and stacked the radial receiver functions using the common conversion point method (Zhu 2000). The resulting image shows two main velocity interfaces marked by positive-polarity Ps-conversions (red-toyellow regions in Fig. 5a), corresponding to downward velocity increase at the European and Adriatic Mohos (thick dashed lines 1 and 2 in Fig. 5a), and a main blue spot of negative-polarity Ps-conversions located beneath the Dora-Maira (3 in Fig. 5a).

The eastward-dipping European Moho (1 in Fig. 5a) can be recognized in the RF image from $\sim 40 \mathrm{~km}$ depth beneath the Frontal Pennine Fault (FPF in Fig. 5a) to $\sim 75 \mathrm{~km}$ depth beneath the Po Plain. In the European foreland, the velocity interface marked by positive-polarity Ps-conversions is located at $\sim 30-40 \mathrm{~km}$ depth and is clearly connected with the European Moho imaged by previous work (e.g., Thouvenot et al. 2007). According to Zhao et al. (2015), the eastward weakening of this converted phase beneath the Alpine subduction wedge, as highlighted by the progressive change in color from red to yellow in Fig. 5a, may be due to eclogitization of the European lower crust at depth $>40 \mathrm{~km}$, and consequent reduction of the density (and velocity) contrast with the underlying lithospheric mantle.

The Adriatic Moho ( 2 in Fig. 5a) can be recognized in the RF image from 10-15 km depth, to the West, to $20-30 \mathrm{~km}$ depth to the East, where it is connected with the Adriatic Moho imaged beneath the Po Plain by independent studies (e.g., Molinari et al. 2015). In the westernmost Po

This article is protected by copyright. All rights reserved. 
Plain, this velocity interface coincides with the top of the so-called "Ivrea body" (Closs and Labrouste 1963), classically interpreted as a slice of Adriatic upper mantle (Nicolas et al. 1990a; Kissling 1993; Paul et al. 2001; Scafidi et al. 2009) exhumed at shallow crustal depth during Tethyan rifting (Manatschal and Bernoulli 1999; Malusà et al. 2015).

The main spot of negative-polarity Ps-conversions ( 3 in Fig. 5a) is located between 20 and $40 \mathrm{~km}$ depth beneath the Dora-Maira massif. It likely marks a downward velocity decrease from mantle rocks to (U)HP rock slivers and/or associated serpentinites of the suture zone (Zhao et al. 2015; Malusà et al. 2017). The hypothesis of dominant (U)HP continental slivers would be consistent with the predictions of numerical models of synconvergent exhumation (e.g., Jamieson and Beaumont 2013), whereas the hypothesis of dominant serpentinites would be in line with the predictions of numerical models of exhumation triggered by divergence between upper plate and accretionary wedge (e.g., Liao et al. 2018b), which are more consistent with the geologic record available for the Western Alps (Malusà et al. 2011, 2015). Constraints provided by RF allowed to define preliminary two-dimensional models of layer boundaries and velocity contrasts along the CIFALPS profile, which were tested by Zhao et al. (2015) for compatibility with available Bouguer anomaly data by gravity modelling (Fig. 5d). However, Zhao et al. (2015) could not assess the relative proportion of serpentinites and (U)HP rock slivers in the region marked by negative polarity conversions. Such evaluation requires absolute Vp and Vs constraints that were provided, at a later stage of the CIFALPS project, by local earthquake tomography (Solarino et al. 2018) and TransD inversion of surface-wave data (Zhao et al. 2020) as described in Sect. 7.

\subsection{Moho imaging by other tomographic methods}

Breakthroughs provided by RF analysis using teleseismic events have been subsequently confirmed, along the CIFALPS transect, by different seismic data sets and tomographic methods (Fig. 5b). These methods include: (i) tomography from ambient seismic noise (Lu et al. 2018); (ii) local earthquake tomography (Solarino et al. 2018); (iii) tomography from teleseismic fullwaveform inversion (Beller et al. 2018); and (iv) tomography from Bayesian transdimensional inversion of Rayleigh wave group velocity dispersion data (Zhao et al. 2020).

Ambient noise tomography (ANT) is particularly efficient to image the velocity structure of the crust and uppermost mantle, provided that continuous noise records are available at dense arrays of seismic stations (Shapiro et al. 2005). Rayleigh waves between stations can be reconstructed from the cross-correlation of recorded seismic noise, basically turning each station to a source of seismic waves (e.g., Campillo and Paul 2003; Larose et al. 2006). In the Alpine region, Lu et al. (2018) used noise correlations to compute Rayleigh wave phase and group velocity and derive a high-resolution 3-D S-wave velocity model. Their dispersion dataset took advantage of the large number of seismic stations in Europe, particularly the great Alpine region with the high-density CIFALPS (Zhao et al. 2016a) and AlpArray (Hetényi et al. 2018) temporary experiments. The depth to the European Moho estimated from ANT beneath the Frontal Pennine Fault and surroundings (green line in Fig. 5b) (Lu et al. 2018) is in good agreement with the Moho depth estimated from RF. At the western end of the profile, the ANT Moho beneath the Southeast Basin is shallower than the RF Moho by $5-8 \mathrm{~km}$, which could be due to an inappropriate velocity model for the migration of RF. Beneath the Po Plain, and on top of the Ivrea body, the Adriatic Moho estimated from ANT correlates well with the RF Moho (Fig. 5b).

Moho constraints are also provided by local earthquake tomography (LET). The LET method is based on the analysis of earthquakes within the model volume (Kissling 1988). The maximum

This article is protected by copyright. All rights reserved. 
depth of the resolved model is thus limited by the depth of occurrence of the deepest seismic events. The investigated volume needs to be adequately sampled by a dense set of crossing rays, depending on the distribution of both earthquakes and receivers, in order to resolve the inherent trade-off between variations in velocity structure and hypocentre locations. Along the CIFALPS transect, the P-wave velocity structure provided by LET can be locally resolved down to $50-60 \mathrm{~km}$ depth (Solarino et al. 2018) using the anomalously deep earthquakes recorded in the western Po Plain (Eva et al. 2015; Malusà et al. 2017). The Adriatic Moho estimated from LET beneath the Po Plain and on top of the Ivrea body (thick grey line in Fig. 5b) confirms the results of RF analysis, providing an even more reliable estimate of Moho depth compared to previous results based on RF alone (see Sect. 7.1 for more details). Only part of the European Moho, i.e., the part located beneath the External Zone, lays within the resolved LET model volume. There, the LET Moho confirms the location of the RF Moho as revealed by analysis of teleseismic events (Solarino et al. 2018).

A further independent image of the European Moho along the CIFALPS transect is based on full-waveform inversion (FWI) of selected teleseismic events recorded during the CIFALPS experiment (Beller et al. 2018). By FWI is meant the inversion of the full seismogram including phase and amplitude effects, within a time window following the first arrival up to a frequency of $0.2 \mathrm{~Hz}$. Based on FWI, Beller et al. (2018) built 3-D models of density and P- and S-wave velocities, and detected the European Moho (blue line in Fig. $5 \mathrm{~b}$ ) at depths ranging from $\sim 30 \mathrm{~km}$ beneath the Southeast Basin to $\sim 65 \mathrm{~km}$ beneath the Dora-Maira massif, which confirms previous results based on RF.

A more recent Moho image along the CIFALPS transect is based on a Bayesian transdimensional (TransD) inversion of the Rayleigh wave group velocity dispersion data of Lu et al. (2018), as performed by Zhao et al. (2020) according to the procedure described in Bodin et al. (2014) and Yuan and Bodin (2018). TransD inversion provides absolute S-wave velocity information and treats the model parameterization (e.g., the number of velocity layers) as an unknown in the inversion to be determined by the data, thus yielding more robust velocity amplitude estimates (Bodin et al. 2012a, b). The resulting image presented by Zhao et al. (2020) provides compelling evidence of European continental-crust subduction into the Adriatic upper mantle (see Sect. 7.2 for more details), thus confirming the main findings of RF analysis. The eastward-dipping TransD European Moho (red line in Fig. 5b) is located at $~ 30 \mathrm{~km}$ depth beneath the Southeast Basin, getting progressively deeper from $\sim 45 \mathrm{~km}$ depth beneath the Frontal Pennine Fault to $\sim 75 \mathrm{~km}$ depth beneath the Dora-Maira massif. On the eastern side of the CIFALPS transect, the TransD Moho overlaps with the Adriatic Moho as imaged by RF, ANT and LET (Fig. $5 b)$.

\section{Absolute velocity structure of the crust and the mantle wedge}

A more detailed geologic interpretation of the crustal structure along the CIFALPS transect requires absolute $\mathrm{P}$-wave and $\mathrm{S}$-wave velocity constraints. These constraints are provided by LET (Solarino et al. 2018) and TransD inversion of Rayleigh wave dispersion data (Zhao et al. 2020) and are illustrated below.

\subsection{Absolute P-wave velocity structure from $L E T$}

The absolute P-wave velocity structure revealed by LET in the southern Western Alps (Solarino et al. 2018) is shown in Fig. 6. In order to improve ray crossing (Fig. 6a) and better

This article is protected by copyright. All rights reserved. 
constrain the bottom part of the study volume, Solarino et al. (2018) have integrated recordings of the CIFALPS stations with recordings of permanent stations operating during the CIFALPS experiment, and have also considered the intermediate depth earthquakes that occurred before the experiment (Eva et al. 2015). The well-resolved regions of the resulting LET model include the European crust to the west, the Adriatic crust and uppermost Adriatic mantle to the east, and the Alpine subduction wedge (Solarino et al. 2018) (Fig. 6 b, c).

The European upper crust (EUC in Fig. 6c) shows Vp values $<6.4 \mathrm{~km} \mathrm{~s}^{-1}$ and rather constant $\mathrm{Vp} / \mathrm{Vs}$ ratios $\sim 1.70 \pm 0.02$, consistent with a mainly granitic continental crust (cf. Fig. 4). Vp values increase in the European lower crust (ELC in Fig. 6c) from Vp $\sim 6.7 \mathrm{~km} \mathrm{~s}^{-1}$, at depth of $\sim 25 \mathrm{~km}$, to $\mathrm{Vp} \sim 7.6 \mathrm{~km} \mathrm{~s}^{-1}$ at depth $>40 \mathrm{~km}$ (i.e., beneath the Alpine subduction wedge), under rather constant $\mathrm{Vp} / \mathrm{Vs}$ ratios of $1.70-1.72$. The observed velocity structure suggests a relatively homogeneous lower crust at the scale of seismic observations along the CIFALPS profile. Vp values $\sim 6.7 \mathrm{~km} \mathrm{~s}^{-}$ ${ }^{1}$ in the lower crust are consistent with granulitic rocks of felsic to intermediate compositions (Rudnick and Fountain 1995; Weiss et al. 1999; Goffé et al. 2003; Wang et al. 2005; Mechie et al. 2012). Major occurrence of granulitic metapelites can be excluded in the light of their higher Pwave velocities (up to $7.2 \mathrm{~km} \mathrm{~s}^{-1}$; see Fig. 4), which is not observed in the western part of the CIFALPS profile. The progressive increase in P-wave velocities at depth $>40 \mathrm{~km}$ may mirror the progressive eclogitization of the European lower crust (Solarino et al. 2018), as eclogitization of a felsic granulite strongly increases the garnet content and consequently the rock density (from 2.90 to $3.3010^{3} \mathrm{~kg} \mathrm{~m}^{-3}$ ) and P-wave velocity (up to $7.6 \mathrm{~km} \mathrm{~s}^{-1}$ ) (e.g., Christensen 1989; De Paoli et al. 2012; Hacker et al. 2003, 2015; Hacker and Abers 2004; Hetényi et al. 2007). Alternatively, the increase in P-wave velocity in the European lower crust may indicate an increase in mafic component beneath the Alpine subduction wedge. However, Vp values provided by LET are far too low for a pure mafic eclogite (7.9 to $8.7 \mathrm{~km} \mathrm{~s}^{-1}$; Bezacier et al. 2010; Reynard 2013) (Fig. 4). Zhao et al. (2015) and Solarino et al. (2018) have thus favoured the hypothesis of a progressive change in metamorphic assemblages during continental subduction rather than a change in bulk composition from west to east. The progressive P-wave velocity increase in the European lower crust at depth $>40 \mathrm{~km}$, as documented by LET, provides an explanation for the eastward weakening of RF converted phases along the European Moho described by Zhao et al. (2015) (see Fig. 6d).

On the eastern side of the CIFALPS transect, the LET model shows a sharp downward Pwave velocity increase across the Adriatic Moho (thick dashed line 2 in Fig. 6c). Above the Adriatic Moho, the Adriatic upper crust (AUC in Fig. 6c) shows Vp values $<6.4 \mathrm{~km} \mathrm{~s}^{-1}$ and Vp/Vs ratios $~ 1.70-1.74$. The Adriatic lower crust (ALC in Fig. 6c) shows a more complex velocity structure than the European lower crust, likely reflecting a more heterogeneous composition at the scale of seismic observations. Local spots with $\mathrm{Vp} \sim 7.2 \mathrm{~km} \mathrm{~s}^{-1}$ and low $\mathrm{Vp} / \mathrm{Vs}$ ratios may suggest, according to Solarino et al. (2018), local occurrences of granulite-facies metapelites ( $\mathrm{Vp}=6.3-7.2$ $\mathrm{km} \mathrm{s}^{-1}$, Vs=3.8-4.1 $\mathrm{km} \mathrm{s}^{-1}$; Weiss et al. 1999; Khazenehdari et al. 2000). North of the Po Plain, similar granulite facies metapelites are also exposed at Earth's surface (e.g., Ewing et al. 2014). In the region labelled as $\mathrm{ALC}_{1}$ (Fig. 6c), the locally high $\mathrm{Vp} / \mathrm{Vs}$ ratios $>1.8$ associated to $\mathrm{Vp} \sim 7.0-7.3$ $\mathrm{km} \mathrm{s}^{-1}$ may be interpreted as gabbro underplated at the base of the Adriatic lower crust. Permian gabbros are indeed exposed at Earth's surface north of the Po Plain, and intrude lower crustal rocks belonging to the Adriatic (Southalpine) basement (Quick et al. 1994; Schaltegger and Brack 2007). Below the Adriatic Moho, seismic velocities provided by LET are consistent with dry to partly serpentinized peridotites of the Adriatic lithospheric mantle (AM in Fig. 6c), as indicated by Vp values $\sim 7.5-8.0 \mathrm{~km} \mathrm{~s}^{-1}$ and $\mathrm{Vp} / \mathrm{Vs}$ ratios $\sim 1.70-1.72$. Peridotites are found at depth $>30 \mathrm{~km}$ beneath the Monferrato, and at much shallower depth (10-15 km) in correspondence with the Ivrea positive

This article is protected by copyright. All rights reserved. 
gravity anomaly, in line with results of previous tomography models (Solarino et al. 1997; Paul et al. 2001; Scafidi et al. 2006, 2009; Diehl et al. 2009; Wagner et al. 2012).

In the central part of the CIFALPS transect, the uppermost part of the Alpine subduction wedge shows $\mathrm{Vp}$ values invariably $<6.5 \mathrm{~km} \mathrm{~s}^{-1}$ (Fig. 6c). The structural variability in this region is mirrored by the variability in $\mathrm{Vp} / \mathrm{Vs}$ ratios. $\mathrm{Vp} / \mathrm{Vs}>1.75$ in the Briançonnais and Schistes Lustrés units likely reflect low $\mathrm{S}$-wave velocities resulting from a widespread network of mesoscale faults developed in these units during the Neogene (Sue et al. 2007; Malusà et al. 2009). In the western flank of the Dora-Maira massif, Vp/Vs < 1.66 likely reflect high S-wave velocities, possibly due to the presence of poorly fractured granitic gneisses that are also exposed at Earth's surface (Brossasco granite; Paquette et al. 1999; Lenze and Stöckhert 2007). A prominent feature highlighted by the LET model in this part of the transect is the high velocity body $\left(\mathrm{Vp} \sim 7.5 \mathrm{~km} \mathrm{~s}^{-}\right.$ ${ }^{1}, \mathrm{Vp} / \mathrm{Vs}=1.70-1.72$ ) imaged at depths from $\sim 10 \mathrm{~km}$ to $>30 \mathrm{~km}$ (MW in Fig. 6b, c). This body is exclusively found beneath the Dora-Maira massif, as highlighted by the N-S cross-section of Fig. 6b. It was already imaged with similar velocities by previous work ( $\mathrm{Vp} \sim 7.4-7.7 \mathrm{~km} \mathrm{~s}^{-1}$; Paul et al. 2001; Béthoux et al. 2007) but was only resolved down to depths of 15-20 km (cf. Fig. 2g). Its Pwave velocity is not consistent with dry mantle peridotite or imbricated continental crust rocks as suggested for example by Schmid et al. (2017). Instead, it suggests mantle rocks with variable degrees of serpentinization (Reynard 2013) ranging from $<30 \%$, at depth greater than $30 \mathrm{~km}$, to $>90 \%$ in the uppermost part of the body (see Fig. 4). According to Solarino et al. (2018), this high velocity body may include mantle-wedge rocks exhumed in the late Eocene together with the (U)HP rocks of the Dora-Maira massif, as a result of divergent motion between the Alpine slab and the Adriatic upper plate (Malusà et al. 2011; Liao et al. 2018b). In the southern Western Alps, these mantle-wedge rocks may contribute, together with the Adriatic mantle rocks exhumed during Tethyan rifting, to the positive gravity anomaly classically referred to as the Ivrea gravity anomaly due to the high-density "Ivrea body" (Closs and Labrouste 1963; Nicolas et al. 1990a) (see Fig. $5 d)$.

The bottom part of the LET model of Solarino et al. (2018) provides absolute P-wave velocity constraints to the uppermost part of the Alpine subduction channel (SC in Fig. 6c). At depth $\sim 50 \mathrm{~km}$, in the region located beneath the thick blue spot of RF negative polarity conversions ( 3 in Fig. $6 \mathrm{c}$ ), P-wave velocity is lower than in the nearby Adriatic upper mantle $\left(\sim 7.0-7.5 \mathrm{~km} \mathrm{~s}^{-1} \mathrm{vs} \sim 8.0 \mathrm{~km} \mathrm{~s}^{-1}\right)$. This region may include serpentinites or other lithologies possibly found in a high-pressure mélange zone (Marschall and Schumacher 2012), such as eclogitic metasediments and mafic eclogites. However, the observed velocities $\left(\mathrm{Vp} \sim 7.0-7.5 \mathrm{~km} \mathrm{~s}^{-1} ; \mathrm{Vp} / \mathrm{Vs}<1.70\right)$ are consistent with ultramafic rocks with a degree of serpentinization ranging between 50\% and 75\% (according to Reynard 2013), but they are neither consistent with eclogitic metasediments $\left(\mathrm{Vp} \sim 7.0 \mathrm{~km} \mathrm{~s}^{-1} ; \mathrm{Vp} / \mathrm{Vs} \sim 1.75\right)$ nor with mafic eclogite $(\mathrm{Vp}>7.9$; Vp/Vs 1.73) (Weiss et al. 1999; Reynard 2013). Vp/Vs ratios $\sim 1.74$ indicate that slivers of eclogitic metasediments could be present instead at $\sim 40 \mathrm{~km}$ depth beneath the western flank of the Dora-Maira massif.

In general terms, velocity changes evidenced by LET (Solarino et al. 2018) match with those highlighted by RF analysis (Zhao et al. 2015), despite the different techniques and datasets used (i.e., local vs teleseismic events). Not only do the European and Adriatic Mohos detected by these different techniques show a remarkable fit (see Sect. 6.2), but also the downward velocity decrease revealed by LET from the exhumed mantle wedge to the underlying subduction channel is consistent with the spot of negative-polarity Ps-conversions provided by RF (3 in 6c). A good match is also observed for local anomalies, e.g., the high $\mathrm{Vp} / \mathrm{Vs}$ ratios in region $\mathrm{ALC}_{1}$ (Fig. 6c)

This article is protected by copyright. All rights reserved. 
corresponding to a major break in the alignment of positive-polarity Ps-conversions in the RF image (Fig. 6d).

The shape of the high-velocity region corresponding to the exhumed mantle wedge is mirrored by the distribution of seismic events (Fig. 6d) (Eva et al. 2015; Malusà et al. 2017). The exhumed mantle wedge is virtually aseismic, consistent with the fact that serpentinization promotes aseismic deformation (Peacock and Hyndman 1999; Hilairet et al. 2007). Earthquakes are mainly located in the surrounding regions. To the east, the anomalously deep earthquakes $(30<Z<75 \mathrm{~km})$ recorded beneath the western Po Plain (Cattaneo et al. 1999; Eva et al. 2015) are aligned along an active lithospheric strike-slip fault referred to as the Rivoli-Marene deep fault (RMF in Fig. 6d). Results provided by LET confirm that this left-lateral fault (see focal mechanisms in Fig. 6d) is located in the mantle beneath the Adriatic Moho, as first proposed by Malusà et al. (2017) based on RF results. Vp/Vs values $>1.74$, beside $\mathrm{Vp} \sim 8.0 \mathrm{~km} \mathrm{~s}^{-1}$ at depth around $25-35 \mathrm{~km}$ (Fig. 6c) may reflect low S-wave velocities due to the impact of the RivoliMarene deep fault on the fabric of Adriatic-mantle peridotite (Solarino et al. 2018). In the same region, the azimuthal harmonic decomposition of RF reveals the occurrence of anisotropic rocks (Piana Agostinetti et al. 2017) (Fig. 6d). High-amplitude anisotropic components of RF are observed in places also within the Adriatic crust and along the Adriatic Moho.

\subsection{Absolute S-wave velocity structure from TransD inversion}

The shear wave velocity model of the Western Alps based on TransD inversion of Rayleigh wave group velocity dispersion data (Zhao et al. 2020) is shown in Fig. 7. It provides absolute Vs constraints to the European and Adriatic crust, and a high-resolution image of the velocity structure of the Alpine subduction zone. Figure 7c-e shows three cross-sections of the inverted velocity model down to $90 \mathrm{~km}$ depth, in different sites of the Western Alps corresponding to the NFP-20 West, ECORS-CROP and CIFALPS profiles. Along these cross-sections, the European lithospheric mantle (in blue on the left) is clearly underthrust beneath the Adriatic mantle on the eastern part of each profile (in blue on the right). A major Moho step of $\sim 8 \mathrm{~km}$, first highlighted by $\mathrm{Lu}$ et al. (2018), is detected along the ECORS-CROP profile beneath the Belledonne massif (Fig. 7d). A similar Moho step is observed along the NFP-20 West profile (Fig. 7c) north of the Frontal Pennine Fault. No Moho step is observed along the CIFALPS profile (Fig. 7e).

In the shear wave velocity model of Zhao et al. (2020), the Alpine subduction wedge exhibits a "normal" velocity structure in all three profiles, from Earth's surface to regions 4 and 5 (Fig. 7ce). Vs values progressively increase with depth from $\sim 3.3 \mathrm{~km} \mathrm{~s}^{-1}$ (red to orange colors) in the uppermost levels of the subduction wedge, to $>3.6 \mathrm{~km} \mathrm{~s}^{-1}$ (yellow to green colors) at depth $>40$ $\mathrm{km}$. This normal velocity structure is consistent with expected Vs values in metapelites and gneisses exposed in the Alpine belt, and with a progressive Vs increase with depth. Very low Vs regions (dark red) correspond to the main sedimentary basins formed atop the European and Adriatic crusts (Southeast basin and Po Plain, respectively). The lateral extent of the low Vs material ascribed to the subduction wedge can be evaluated in the horizontal slices of the tomography model at 50 and $60 \mathrm{~km}$ depth (Fig. 7a, b). The region with Vs $<3.8 \mathrm{~km} \mathrm{~s}^{-1}$ (green to yellow colors), detected all along the arc of the Western Alps at $60 \mathrm{~km}$ depth (Fig. 7b), is apparently thicker in the northern Western Alps compared to the southern Western Alps.

On the eastern side of each cross-section, the culmination of the region with $\mathrm{Vs}>4.0 \mathrm{~km} \mathrm{~s}^{-1}$ (marked by blue colors) invariably matches with the location of the Ivrea gravity anomaly shown in Fig. 1b. A region with Vs $>3.8 \mathrm{~km} \mathrm{~s}^{-1}$ is imaged beneath the Dora-Maira starting from $\sim 10 \mathrm{~km}$

This article is protected by copyright. All rights reserved. 
depth. This region has a similar shape, with a near-vertical western boundary, as the high Vp anomaly imaged beneath the Dora-Maira by LET along the same profile (Fig. 6c). A similar highvelocity region is not observed beneath the eclogitic domes farther north (Fig. 7c, d), in line with results provided by LET (Solarino et al. 2018). At 50-70 km depth along the CIFALPS profile, the inverted model also shows a region with $\mathrm{Vs}<3.7 \mathrm{~km} \mathrm{~s}^{-1}$ (green to yellow colors) that is interposed between the European lithospheric mantle and the overlying Adriatic mantle (6 in Fig. 7e). This low-velocity region, which reverts a trend of progressively increasing Vs with depth, is not observed along the ECORS-CROP and NFP-20 West profiles (cf. Fig. 7c, d). It has been interpreted by Zhao et al. (2020) as the evidence of serpentinites preserved along the Alpine subduction channel. In fact, the decreasing Vs values from region 5 to region 6 cannot be explained by metamorphic phase changes in metapelites and gneisses. The only rock characterized by Vs values of $\sim 3.6 \mathrm{~km} \mathrm{~s}^{-1}$ in the $55-70 \mathrm{~km}$ depth range is serpentinite (Fig. 4). Alternatively, the low Vs values in region 6 may be due to high pore-fluid pressures, which would in turn promote serpentinization. A sharp Vs increase, observed at depth $>70 \mathrm{~km}$ along the Alpine subduction channel, may reflect destabilization of antigorite and transformation of subduction-channel serpentinite into peridotite (e.g., Reynard 2013).

\section{Velocity structure in the upper mantle along the CIFALPS profile}

For a reliable geologic interpretation of the upper mantle structure along the CIFALPS profile, seismic velocity constraints of the slab structure and the mantle flow in the surrounding asthenosphere are required. Crucial for the interpretation of seismic velocities in the Alpine upper mantle is also the location of the lithosphere-asthenosphere boundary beneath the European foreland and the Alpine subduction wedge. Within the framework of the CIFALPS experiment, this information is provided by array analysis of seismic surface waves (Lyu et al. 2017). Information concerning the deeper slab structure is provided by teleseismic P-wave tomography (Zhao et al. 2016b), whereas clues on asthenospheric mantle flow are provided by the analysis of seismic anisotropy (Salimbeni et al. 2018).

\subsection{The lithosphere-asthenosphere boundary beneath the Alpine foreland areas}

The depth of the lithosphere-asthenosphere boundary beneath the Alpine region has been investigated by Lyu et al. (2017) using a combination of CIFALPS and permanent seismic station data. Lyu et al. (2017) inverted the fundamental mode Rayleigh wave dispersion curves for Vs using the crustal interfaces imposed from RF (Zhao et al. 2015). The resulting Vs values, derived from independent measurements in each mini-array, are shown in Fig. 8a. Vs values vary smoothly across the profile length. The decrease in S-wave velocity below $\sim 110 \mathrm{~km}$ depth in the western part of the profile (Fig. 8a) has been interpreted by Lyu et al. (2017) as the lithosphereasthenosphere boundary beneath the European foreland. The top of this low-velocity layer, marked by a thick dashed line in Fig. 8a, is approximately parallel to the eastward dipping European Moho as detected by RF and other methods, which suggests a $\sim 110 \mathrm{~km}$ thick and eastward-dipping European lithosphere. These findings are consistent with the lithospheric thickness generally observed in Phanerozoic Europe using surface waves (e.g., Dost 1990; Cotte et al. 2002) and Sreceiver functions (Geissler et al. 2010). S-wave velocities retrieved by Lyu et al. (2017) in the European upper mantle are overall low, at least when compared with velocities of the AK135 model (Kennett et al. 1995). S-wave velocities are much higher in the Adriatic lithosphere $(\sim 5 \mathrm{~km}$ $\mathrm{s}^{-1}$, dark blue colors in Fig. 8a), and consistent with a lithosphere-asthenosphere boundary located

This article is protected by copyright. All rights reserved. 
at 100 km depth beneath the Po Plain, as proposed by Brandmayr et al. (2010) and Malusà et al. (2018).

\subsection{Velocity structure beneath the Alpine subduction wedge}

According to Lyu et al. (2017), very low Vs values $<4 \mathrm{~km} \mathrm{~s}^{-1}$ are found at the base of the European lithosphere in the central part of the CIFALPS profile, at depth $\sim 120 \mathrm{~km}$ beneath the Alpine subduction wedge ( 7 in Fig. 8a). In that region, the high-velocity anomaly imaged by teleseismic P-wave tomography is strongly attenuated (Lippitsch et al. 2003; Zhao et al. 2016b; see Sect. 8.3), and a low-Vs anomaly has been also detected by FWI (Beller et al. 2018) (7 in Fig. 8b). This is illustrated in the composite cross-section of Fig. 8b, which combines in the upper panel the results of TransD inversion of surface-wave dispersion data (Zhao et al. 2020), and in the lower panel the Vp perturbations based on teleseismic P-wave tomography (Zhao et al. 2016b). The Vs anomaly derived from FWI and described by Beller et al. (2018) is shown as purple isolines (Fig. $8 b)$. Note that these different models are based on different data, obtained by means of different techniques and their resolving power is also different. Beller et al. (2018) have suggested that the low-Vs anomaly detected in their S-wave velocity model may be supportive of a slab detachment beneath the Western Alps, an interpretation recently reintroduced by Dal Zilio et al. (2020) and Kästle et al. (2020). However, when the low-Vs anomaly detected by Beller et al. (2018) is analysed in more detail and compared with information provided by independent tomographic methods along the CIFALPS profile (Fig. 8b), a different scenario emerges. The anomaly shows in fact two peaks, a weaker one at the base of the European lithosphere (7 in Fig. 8 b) and a stronger one at $\sim 75-95 \mathrm{~km}$ depth along the subduction channel above the European slab ( 8 in Fig. 8b). The anomaly 8 is not present in the TransD inversion model of Zhao et al. (2020) because it lays in a region where the model is not well resolved (cf. Zhao et al. 2020, their Fig. S9). Along the subduction channel, low Vs values in the 55-70 km depth range (6 in Fig. 8b) likely mark the occurrence of serpentinite (see Sect. 7.2). Given the sharp Vs increase at depth $>70 \mathrm{~km}$ along the subduction channel (Fig. 8b), interpreted by Zhao et al. (2020) as due to transformation of serpentinite into peridotite after destabilization of antigorite (cf. Fig. 4), the low Vs anomaly detected by Beller et al. (2018) at 75$95 \mathrm{~km}$ depth (8 in Fig. 8b) may also indicate a metasomatized mantle peridotite due to infiltration of slab fluids. We conclude that comparison among different techniques underlines that the results provided by Beller et al. (2018) are not supportive of European slab detachment. Instead, they are consistent with the results provided by other tomography approaches that have been applied during the CIFALPS experiment (e.g., Lyu et al. 2017; Zhao et al. 2020).

\subsection{Slab structure from teleseismic P-wave tomography}

Previous seismic tomography models of the Alpine upper mantle have revealed more or less discontinuous P-wave velocity anomalies interpreted as the seismic signature of subducted lithospheric slabs (e.g., Wortel and Spakman 2000; Lippitsch et al. 2003; Piromallo and Faccenna 2004). However, interpretations in terms of slab length and lateral or vertical slab continuities strongly depend on the resolution of seismic tomography models. The Zhao et al. (2016b)'s tomography study performed within the framework of the CIFALPS experiment first benefited from the recent opening of the European seismic databases and improvement of the permanent broadband network. It is based on a much denser station coverage than any previous work, especially in the Western Alps. Data were recorded by 527 broadband seismic stations: 449 from permanent networks, 23 from the PYROPE temporary experiment (Chevrot et al. 2014) and 55 from the CIFALPS experiment. In order to avoid interference of upper mantle tomography by crustal anomalies, Zhao et al. (2016b) used the EPcrust reference model to correct for traveltime

This article is protected by copyright. All rights reserved. 
residuals within the crust (Molinari and Morelli 2011). Although the EPcrust model does not include all the details of the most recent Moho maps (e.g., Spada et al. 2013; Lu et al. 2020), and the approach chosen by Zhao et al. (2016b) does not include the effects of 3-D propagation of nonvertical rays from different azimuths in the heterogeneous crust (e.g., Waldhauser et al. 2002), synthetic tests performed by Zhao et al. (2016b) indicate that their tomography model of Vp perturbations is not significantly affected by smearing of crustal anomalies to mantle depth.

Teleseismic tomography models of Vp perturbations display lateral P-wave velocity changes with respect to the horizontally averaged $\mathrm{Vp}$ in the region crossed by incident $\mathrm{P}$ waves. They are not associated to a reference model. The lower panel of Fig. 8b shows a cross-section of the Zhao et al. (2016b)'s model along the CIFALPS profile down to $400 \mathrm{~km}$ depth. The cross-section includes strong low-velocity anomalies (9 in Fig. 8 b) at 100-250 km depth beneath the Frontal wedge and the European foreland, and an E-dipping high-velocity anomaly (blue in Fig. 8b) beneath the Eclogite belt and the western Po Plain. This high-velocity anomaly, likely marking the European slab beneath the Western Alps, is continuous from the uppermost mantle where it links with the lithosphere-asthenosphere boundary detected by array analysis of seismic surface waves (Lyu et al. 2017) and with the European Moho recognized by RF and TransD inversion (Zhao et al. 2015, 2020). Specific resolution tests suggest that any major slab gap should be revealed by the model, if present. According to the tomography model, the inferred length of the Western Alps slab may reach $\sim 300 \mathrm{~km}$ (cf. Malusà et al. 2015, their Fig. 6), but such estimate should be taken with caution due to the potential vertical smearing typical of teleseismic body-wave tomography images. The Zhao et al. (2016b)'s model also shows a weakening of the high-velocity anomaly at the base of the European lithosphere (7 in Fig. 8b), supported by the results of subsequent work by Lyu et al. (2017) and Beller et al. (2018) discussed in Sect. 8.1-8.2. Such weakening affects part, but not the entire thickness of the Western Alps slab.

\subsection{Comparison with other tomography models}

The continuity of the high-velocity anomaly in the Zhao et al. (2016b)'s model along the CIFALPS profile contrasts with those interpretations (e.g., Fox et al. 2015; Kissling and Schlunegger 2018; Kästle et al. 2020) based on the Lippitsch et al. (2003)'s model that have suggested slab breakoff beneath the Western Alps (see also Fig. 3c). Kissling and Schlunegger (2018) rejected the Zhao et al. (2016b)'s interpretation of a continuous slab in the Western Alps using the arguments that the Zhao et al. (2016b)'s model would be mainly based on 2-D information and poor quality data, which is incorrect as it is based on data from >500 stations distributed in the entire Alpine region (grey triangles in Fig. 1a), including 29 months of data at 449 high-quality broadband permanent stations. Cross-sections of these different tomographic models are compared in Fig. 9: the Lippitsch et al. (2003)'s ray-based model (on the left in Fig. 9) has a horizontal grid size of $50 \mathrm{~km}$, it is based on $\sim 4,200$ traveltime measurements and it was the first to suggest a slab breakoff beneath the Western Alps; the Zhao et al. (2016b)'s kernel-based model (on the right in Fig. 9) has a denser horizontal grid size of $25 \mathrm{~km}$, it is based on $\sim 42,000$ traveltime measurements and was the first to explicitly propose a continuous slab under the Western Alps, although similar evidence is also provided by teleseismic tomography models from other working groups (e.g., Piromallo and Morelli 2003; Koulakov et al. 2009; Giacomuzzi et al. 2011; Hua et al. 2017; Paffrath et al. 2020). As shown in Fig. 9, the first-order features of the Lippitsch et al. (2003)'s and Zhao et al. (2016b)'s models are remarkably similar, despite interpretations that are quite different (for the sake of clarity, the contours of equal $\mathrm{Vp}$ anomaly in the Lippitsch et al. (2003)'s model are also plotted onto the Zhao et al. (2016b)'s model to the

This article is protected by copyright. All rights reserved. 
right). Both models show low-Vp anomalies located beneath the European foreland and a high-Vp anomaly under the western Po Plain that becomes weaker at $\sim 120 \mathrm{~km}$ depth (7 in Fig. 9). The 0\% anomaly isoline in the Lippitsch et al. (2003)'s model largely matches the boundary between high$\mathrm{Vp}$ and low-Vp perturbations in the Zhao et al. (2016b)'s model. The observed differences in the amplitudes of $\mathrm{Vp}$ perturbations between models are not informative, because the kernel-based models (e.g., the finite frequency method used in Zhao et al. 2016b) generally yield higher rootmean square amplitudes for Vp perturbations than the ray-based method (e.g., Lippitsch et al. 2003).

Evidence of potential slab breakoff and associated passive asthenospheric upwelling along the breakoff gap should include, in a teleseismic P-wave tomography model, a low-velocity anomaly cutting across the high-velocity anomaly representing the broken slab. However, the shape of the anomaly is generally retrieved much better than its amplitude. Within the framework of the CIFALPS experiment, Zhao et al. (2016b) performed a series of tests, e.g., by replacing part of the high-velocity slab with a low-velocity body extending from 80 to $140 \mathrm{~km}$ depth, in order to mimic a possible slab breakoff beneath the CIFALPS profile. They found that the shape of a lowvelocity body, if present, would be well recovered as a low-velocity anomaly by the inversion, albeit with attenuated amplitude (see Zhao et al. 2016b, their Fig. 5). They also demonstrated that a strong high-velocity anomaly in the crust like the Ivrea body does not smear to mantle depth and could by no way erase or attenuate a possible low-velocity anomaly in the mantle related to slab breakoff (see Zhao et al. 2016b, their Fig. 6). Within this framework, it is worth noting that the small low-velocity anomaly at $\sim 120 \mathrm{~km}$ depth detected by Lippitsch et al. (2003) under the DoraMaira is not connected, in their model, with the main low-velocity anomaly beneath the European foreland (see the left panel in Fig. 9). In fact, the two regions are separated by a region with Vp $(\%)>0$. Based on these considerations, the Lippitsch et al. (2003)'s model may provide no clear support to the hypothesis of a slab detachment along the CIFALPS profile, which would also imply a much stronger and continuous negative anomaly beneath the Dora-Maira.

The right panel of Fig. 9 also includes the fast Vs anomaly imaged by Kästle et al. (2018) by analysis of surface wave dispersion data from ambient noise and earthquakes (black hatched area in Fig. 9). The Kästle et al. (2018)'s model is sometimes invoked, together with the Lippitsch et al. (2003)'s and the Beller et al. (2018)'s models, to support the hypothesis of a detached slab beneath the Western Alps (see discussion in Kästle et al. 2020). However, the recent review paper by Kästle et al. (2020) may suggest that the Kästle et al. (2018)'s model does not provide an accurate image of the subducted lithosphere beneath the Western Alps. Indeed, the body-wave tomography models compared by Kästle et al. (2020) in their Fig. 2 (Lippitsch et al. 2003; Koulakov et al. 2009; Zhao et al. 2016b) invariably include an ENE-WSW trending high-Vp anomaly located to the south and well outside the Switzerland borders in the 120 and $200 \mathrm{~km}$ depth slices, whereas the Kästle et al. (2018)'s model, by contrast, shows an E-W trending high-Vs anomaly that is located more to the north and within the Switzerland borders.

\subsection{Seismic anisotropy}

The birefringence of core-refracted shear waves (SKS phase) and associated transverse anisotropy of seismic velocities (Savage 1999; Mainprice et al. 2000) can provide information on the lattice-preferred-orientation of olivine crystals in the mantle. Salimbeni et al. (2018) analysed the seismic anisotropy properties beneath seismic stations of the CIFALPS profile using the waveforms of 40 teleseismic events with $\mathrm{Mw}>5.8$, considering the azimuth of the fast axis $(\varphi)$ and the delay time (dt) as proxies for the preferred orientation of olivine $a$ axes and the thickness

This article is protected by copyright. All rights reserved. 
of the anisotropic layer (Silver et al. 1999). The resulting distributions of delay times and fast axis orientations are plotted in Fig. $8 \mathrm{c}$ using different colours according to the back-azimuth of the seismic events.

Three different segments of the CIFALPS profile (western, central and eastern segments) are distinguished by Salimbeni et al. (2018) based on seismic anisotropy data. The western segment shows quite homogeneous fast-axis directions in the range of $-60^{\circ} \pm 20^{\circ}$, with minor differences depending on the back-azimuth. Along the western segment, ray paths coming from the West (dark blue marks in Fig. 8c) show increasing delay times from $\sim 1 \mathrm{~s}$ (at abscissae $\sim 40 \mathrm{~km}$ ) to $\sim 2.4 \mathrm{~s}$ (at abscissae $\sim 140 \mathrm{~km}$ ). In the central segment, ray paths coming from the West (dark blue marks) define a trend of linearly decreasing delay times from $\sim 2.4 \mathrm{~s}$ (at abscissae $\sim 140 \mathrm{~km}$ ) to $\sim 1.0 \mathrm{~s}$ (at abscissae $\sim 220 \mathrm{~km}$ ). No such trend is observed in the eastern segment of the profile, where the fast-axis directions are much more dispersed and the delay time is strongly scattered in a range from $<1 \mathrm{~s}$ to $2.8 \mathrm{~s}$. The abrupt change in seismic anisotropy pattern between the central and the eastern segments of the CIFALPS profile occurs in correspondence with the transition (green dashed line in Fig. 8b,c) between the high-velocity anomaly marking the Western Alps slab and the low velocity anomaly detected to the west. West of the green dashed line, delay time variations for ray paths coming from the west show some correlation with the low P-wave velocity perturbations shown in Fig. 8b (red to yellow colors): higher delay times are found where the lowvelocity anomaly in the mantle is weaker (i.e., at abscissae $\sim 140 \mathrm{~km}$ ), whereas lower delay times are found where the low-velocity anomaly in the mantle is stronger. A geologic interpretation of this seismic anisotropy pattern requires a 3-D analysis of delay times and fast-axis directions with respect to the slab structure of the entire Alpine region, which is presented in Sect. 9.

\section{Slab structure of the broader Alpine region}

The complex slab structure of the broader Alpine region is still actively debated (e.g., Schmid et al. 2013; Handy et al. 2015; Rosenberg et al. 2018; Ji et al. 2019; Kästle et al. 2020). Within the framework of the CIFALPS experiment, useful pinpoints are provided by teleseismic P-wave tomography (Zhao et al. 2016b) and 3-D Pn tomography (Sun et al. 2019).

\subsection{Continental subduction from 3-D Pn tomography}

Sun et al. (2019) mapped the seismic velocity signature of continental subduction in the broader Alpine region by inversion of Pn phase traveltimes, using data recorded by permanent and temporary stations since the 1960s (Fig.1a). Pn phases, i.e., the first arrivals at regional distance, propagate through the crust, penetrate the uppermost mantle and are finally refracted at the Moho and return to the free surface (Hearn 1999). The tomography model of Sun et al. (2019) is based on a three-step 3-D approach (Sun and Kennett 2016a, b) applied to a dataset of $>395,000 \mathrm{Pn}$ arrivals for $>9500$ events and 1080 stations, and provides absolute P-wave velocities in the uppermost $80 \mathrm{~km}$ of the Alpine lithosphere. In their model, the expected seismic velocity signature of continental subduction is given by $\mathrm{P}$-wave velocities lower than those expected for upper-mantle peridotites (i.e., $\mathrm{Vp}<7.7 \mathrm{~km} \mathrm{~s}^{-1}$, see Fig. 4). Oceanic subduction should remain undetected using the Sun et al. (2019)'s approach, because the high Vp values of the oceanic crust after eclogitization ( $\mathrm{Vp}>7.9 \mathrm{~km} \mathrm{~s}^{-1}$ for mafic eclogites) are undistinguishable from the high $\mathrm{Vp}$ values of upper-mantle peridotites (Fig. 4).

The P-wave velocity structure retrieved by Sun et al. (2019) is illustrated in the 50-km depth slice of Fig. 10a. It shows elongated regions characterized by $\mathrm{Vp}<7.7 \mathrm{~km} \mathrm{~s}^{-1}$ (yellow-to-red colors)

This article is protected by copyright. All rights reserved. 
all along the northeastern, northwestern and southwestern boundaries of the Adriatic microplate, providing evidence for continental subduction along the Dinaric, Alpine and Apenninic subduction zones, respectively. The low-velocity belt corresponding to Dinaric subduction displays a remarkable continuity from Austria to Albania. The Dinaric low-velocity belt terminates at highangle (1 in Fig. 10a) against the low-velocity belt of the Eastern Alps, which shows an ENE-WSW trend consistent with major thrust faults formed during Alpine subduction. In the western Alpine region, the low-velocity belts provided by 3-D Pn tomography show an abrupt change in orientation ( 2 in Fig. 10a) likely marking the boundary between the Alpine and Apenninic subduction zones. Underthrusting of continental material by Apenninic subduction can be detected as far north as near Genoa. Prominent breaks ( 3 and 4 in Fig. 10a) are also observed in the Northern and Central Apennines. Higher Vp values in the Southern Apennines suggest that subduction in southern Italy was dominantly oceanic, as also indicated by the geochemistry of subduction-related magmatism (Peccerillo and Frezzotti 2015).

\subsection{Slab structure from Vp anomalies in teleseismic tomography models}

The previously mentioned P-wave tomography model of Zhao et al. (2016b) provides constraints for the upper-mantle velocity structure of the broader Alpine region down to $600 \mathrm{~km}$ depth. The main features of the model are illustrated in Fig. 10 by three horizontal slices at 100, 200 and $300 \mathrm{~km}$ depth (Fig. 10b-d) and by four cross-sections (Fig. 10e). Salient features of the model include the lateral continuity, from the Central Alps to the Western Alps, of the highvelocity anomaly ascribed to the Alpine slab, and the lateral continuity of the high-velocity anomaly ascribed to the Apenninic slab that is particularly evident in the Northern Apennines. In the 100-km depth slice (Fig. 10b), at the transition between the Northern and the Southern Apennines, the model shows a major gap in the Apenninic high-velocity anomaly that was already detected by previous work and interpreted as a potential slab window (Amato et al. 1998; Faccenna et al. 2014). Another important feature of the model is the step between the ENE-WSW trending high-velocity anomaly ascribed to the Alpine slab beneath the Central Alps, and the NW-SE trending high-velocity anomaly detected beneath the Eastern Alps (Zhao et al. 2016b; Hua et al. 2017). The latter is shifted northward and forms an angle of $30^{\circ}$ to $60^{\circ}$ (depending on the depth range) relative to the strike of the Alpine frontal thrusts. The model also shows two main lowvelocity anomalies (yellow-to-red colors in Fig. 10 b-e), labelled as "low Vp anomaly A" and "low $\mathrm{Vp}$ anomaly B" in Fig. 10 b-e. The former is located in the upper mantle of the Western Alps at $100-300 \mathrm{~km}$ depth, and does not extend east of $8^{\circ} \mathrm{E}$. The latter is located in the Adriatic upper mantle beneath the Po Plain, and lays above the Alpine slab (see Fig. 10e, cross-section D-D').

In cross-section, the Zhao et al. (2016b)'s tomography model shows a steep SW-dipping high-velocity anomaly beneath the northern Tyrrhenian region corresponding to the Apenninic slab, and an even steeper NE-dipping high-velocity anomaly beneath the Eastern Alps and the northernmost Dinarides (A-A' in Fig. 10e). The origin of this latter anomaly, also detected by several other tomography models (e.g., Lippitsch et al. 2003; Dando et al. 2011; Mitterbauer et al. 2011; Hua et al. 2017), is still debated. It is either interpreted as due to continental Dinaric subduction during the Neogene (Schmid et al. 2013; Handy et al. 2015), as stemming from an oceanic and detached Alpine slab (Rosenberg et al. 2018), or as resulting from a more complex interaction between the Alpine and Dinaric slabs (Ji et al. 2019; Sun et al. 2019; Kästle et al. 2020) as discussed in more detail in Sect. 9.3. The relationships between the Alpine and Apenninic slabs are clearer. In cross-section B-B' (Fig. 10e), the Alpine slab dips towards the SW and the steeply dipping Apenninic slab is almost overturned to a northeastward dip. The down-dip continuity of the Alpine

This article is protected by copyright. All rights reserved. 
slab in the Central Alps is as debated as in the Western Alps (e.g., Kissling and Schlunegger 2018; Ji et al. 2019; Kästle et al. 2020). The Zhao et al. (2016b)'s model shows a remarkable down-dip continuity of the high-velocity anomaly in the Central Alps (see cross-sections B-B', C-C' and DD' in Fig. 10e) that conflicts with the hypothesis of slab breakoff (e.g., von Blanckenburg and Davies 1995; Kissling and Schlunegger 2018). The amount of subducted lithosphere shown in cross-section D-D' is consistent with the amount of subduction predicted by paleomagnetic and geologic constraints (Handy et al. 2010; Malusà et al. 2015). About $450 \mathrm{~km}$ subduction took place in the Central Alps based on geologic evidence (Malusà et al. 2016a), which is also the amount that can be inferred from the length of the high-velocity anomaly in cross-section D-D'.

\subsection{Interpretive slab structure beneath the Alpine region}

Constraints on the slab structure provided by teleseismic P-wave and 3-D Pn tomography (Zhao et al. 2016b; Sun et al. 2019) are summarized in Fig. 11. Outside of the well-resolved areas of the Zhao et al. (2016b)'s model, slab traces (thick blue lines in Fig. 11a) are based on a previous, lower-resolution tomography model by Piromallo and Morelli (2003). In general terms, there is a good match between the sites of continental subduction documented by 3-D Pn tomography (thick brown lines in Fig. 11a) and the slab structure inferred from teleseismic P-wave tomography, in spite of the different techniques and data sets used (see event locations in Fig. 10f). As shown in the cartoon of Fig. 11b, two opposite-dipping slabs are attached to the southwestern and northeastern boundaries of the Adriatic microplate, forming a reversed U-profile in cross section (Vignaroli et al. 2008; Salimbeni et al. 2013; Zhao et al. 2016b; Sun et al. 2019). To the southwest, the segmented low-Vp belt attesting to subduction of Adriatic crust beneath the Northern Apennines matches with the Apenninic slab trace documented by teleseismic P-wave tomography (Fig. 11a), whereas subduction beneath the Southern Apennines mainly involved Ionian oceanic crust (Fig. 11b). On the northeastern boundary of the Adriatic microplate, the Adriatic crust underthrust beneath the Dinarides is connected with a NE-dipping high-velocity anomaly interpreted as the Dinaric slab (Fig. 11a). The ophiolitic rocks of the Sava and Vardar units exposed farther east (dashed green lines in Fig. 11a) are likely relics of older, Mesozoic subduction zones (Sun et al. 2019).

During the progressive northward motion of the Adriatic microplate in the Cenozoic (Dewey et al. 1989; Jolivet et al. 2003), the Apenninic and Dinaric slabs have likely interacted with the SE-dipping Alpine slab to the North (Malusà et al. 2016b, 2018; Ji et al. 2019). It has been suggested that the interaction between the northward shifting Apenninic slab and the Central Alps slab may have controlled the location of the northern tip of the Ligurian-Provençal basin during Apenninic slab retreat and associated Neogene extension in the Apenninic backarc region (Malusà et al., 2016b). At the transition between the Eastern Alps and the Dinarides, the NEdipping high-velocity anomaly detected in the 100-200 km depth range beneath the remnants of the former Alpine subduction zone (question mark in Fig. 11a) may also provide evidence of the interaction between different slabs. This enigmatic feature may either represent the northern edge of the Dinaric slab, or the overturned remnants of the Alpine slab, or a combination of the two slabs (Salimbeni et al. 2013; Schmid et al. 2013; Zhao et al. 2016b; Rosenberg et al. 2018; Sun et al. 2019; Kästle et al. 2020). Further constraints to the complicated slab structure in that region are expected in the next future from the AlpArray experiment (e.g., Paffrath et al. 2020; Plomerova et al. 2020).

To the West of the Giudicarie Fault, subducted continental material imaged by Pn tomography is clearly connected with the SE-dipping high-velocity anomaly of the Alpine slab,

This article is protected by copyright. All rights reserved. 
which is continuously imaged from the Western to the Central Alps (Fig. 11a). To the east of the Giudicarie Fault, this high-velocity anomaly shows a systematic northward step, interpreted by Ji et al. (2019) as the evidence of a vertical tear in the Alpine slab (Fig. 11), possibly formed after the onset of Dinaric subduction in the Eocene (e.g., Carminati et al. 2012). According to Ji et al. (2019), the interaction between the Alpine and Dinaric slabs, and the consequent progressive steepening of the Alpine slab would explain the timing, distribution and geochemistry of Periadriatic magmatism in the absence of slab breakoff, providing a viable alternative to the classic slab-breakoff model of Periadriatic magmatism proposed by von Blanckenburg and Davies (1995).

Farther South, at the transition between the Alpine and Apenninic slabs, previous tomography models (e.g., Piromallo and Morelli 2003) have suggested the occurrence of a major slab gap. This gap would have allowed the development of an asthenospheric toroidal flow compensating the long-recognized retreat of the Apenninic slab (Vignaroli et al. 2008; Faccenna and Becker 2010; Salimbeni et al. 2013), which is attested to by a progressive migration of Cenozoic orogenic magmatism across the Mediterranean (Fig. 11a) (e.g, Lustrino et al. 2011; Carminati and Doglioni 2012). However, the slab structure revealed by the CIFALPS experiment shows no evidence of a major gap between the Alps and the Apennines at upper mantle depths (Fig. 11b). This finding has major implications for the interpretation of the seismic anisotropy pattern at the scale of the broader Alpine region, as described below.

\subsection{Polyphase development of anisotropic mantle fabrics}

In Fig. 12a, shear wave splitting measurements on CIFALPS data (Salimbeni et al. 2018) and from previous work (Barruol et al. 2004, 2011; Salimbeni et al. 2008, 2013) are plotted on the 150-km depth slice of the Zhao et al. (2016b)'s tomography model as segments parallel to the fast axis and scaled with the delay time. Because the Alpine and Adriatic slabs are both very steep, any depth slice of the Zhao et al. (2016b)'s model would provide similar relationships between velocity anomalies and anisotropy. These relationships reveal a polyphase development of anisotropic mantle fabrics in the Alpine region, which may either reflect fossil or active mantle flows (Salimbeni et al. 2018). Note that the shear wave splitting measurements indicated by the purple segments in Fig. 12a integrate the seismic anisotropy over the uppermost $300 \mathrm{~km}$ and are mainly due to the lattice-preferred-orientation of olivine crystals in the mantle (Savage and Sheehan 2000; Piromallo et al. 2006). In order to discriminate upper mantle and crustal contributions to the observed seismic anisotropy, $\mathrm{S}$ wave anisotropy measurements from local earthquakes (Baccheschi et al. 2019) are also shown in Fig. 12a and are indicated by different shades of green for different depth ranges. However, the contribution of crustal anisotropy to the total seismic anisotropy is minor, as highlighted by the different scales adopted for the different splitting measurements (Fig. 12a). This negligible contribution of crustal anisotropy to total shear-wave splitting measured on SKS phases is confirmed at the scale of the greater Alps by preliminary results from the AlpArray seismic experiment (Link et al. 2020).

According to Salimbeni et al. (2018), shear wave splitting measurements plotting on the high-velocity anomalies of the Zhao et al. (2016b)'s model may reflect fossil fabrics in the lithospheric mantle of the Alpine and Apenninic slabs (1 in Fig. 12a). Fossil fabrics within slabs are generally considered a negligible source of anisotropy (Long and Silver 2008, 2009; Audet 2013). However, a fossil fabric defined by olivine crystallographic preferred orientation (CPO) can be preserved in the oceanic lithosphere since the time of plate formation (Mercier et al. 2008) and is generally aligned with the direction of plate spreading (Shinohara et al. 2008). In the Alpine region, fossil fabrics acquired during Tethyan rifting are described in several mantle slivers

This article is protected by copyright. All rights reserved. 
accreted in the Alpine and Apenninic orogenic belts (e.g., Nicolas et al. 1972; Vissers et al. 1995). They include coarse-grained spinel lherzolite tectonites with olivine CPO consistent with deformation by dislocation creep (Tommasi et al. 1999; Vauchez et al. 2012). This tectonite fabric, developed at $900^{\circ}-1000^{\circ} \mathrm{C}$ and $\sim 1.4 \mathrm{GPa}$ during low-angle simple shearing and asymmetric rifting in the Jurassic (Hoogerduijn Strating et al. 1993), may characterize a thick slab section (Fig. 12b). It is generally overprinted by spinel-, plagioclase-, hornblende- and chlorite-bearing mylonites, and by serpentine mylonites developed as a result of strain localization during progressive mantle exhumation towards the Tethys seafloor (Piccardo and Vissers 2007). Because these fabrics can survive subsequent deformation at eclogitic depths within the Alpine subduction channel (Scambelluri et al. 1995; Hermann et al. 2000), they are also likely preserved in low-strain domains within the slab. Their present-day attitude depends on: (i) the direction of plate spreading, (ii) the trench orientation relative to the paleomargin, and (iii) the present-day slab dip (Fig. 12b). The spreading direction in the Jurassic was likely perpendicular to the trend of the European and Adriatic paleomargins, which is constrained by stratigraphic, tectonic and thermochronologic data (e.g., Winterer and Bosellini 1981; Lemoine et al. 1986; Guillot et al. 2009b; Fantoni and Franciosi 2010; Malusà et al. 2016b), whereas the orientations of the Alpine and Apenninic trenches and the dip angle of the Alpine and Apenninic slabs are well constrained by paleotectonic reconstructions (Jolivet et al. 2003; Vignaroli et al. 2008; Malusà et al. 2015) and available tomography models. Based on the above constraints, the fossil fabrics acquired during Tethyan rifting should be marked, in the Alpine region, by slab-parallel to oblique fast axis directions (Fig. 12b), which are indeed observed in the map of Fig. 12a (Salimbeni et al. 2018). In the Northern Apennines, slabparallel fast-axis directions are detected at depths as shallow as $20 \mathrm{~km}$ (green segments in Fig. 12a) (Baccheschi et al. 2019).

The low Vp anomaly region to the North of the Apenninic slab shows instead NNW-SSE to NE-SW fast-axis directions (2 in Fig. 12a) that are consistent with the direction of relative Adria-Europe plate motion inferred from magnetic anomalies since the Late Cretaceous (Fig. 12c) (Dewey et al. 1989; Jolivet and Faccenna 2000). This suggests that the anisotropic fabric in that region may have formed during post-Jurassic Adria-Europe convergence, and possibly before the onset of Apenninic slab rollback (Salimbeni et al. 2018). If this interpretation is correct, fast-axis directions consistent with Adria-Europe plate motion should be also recorded by seismic stations in the Adriatic Sea (Molinari et al. 2018). WNW-ESE fast-axis directions parallel to the Jurassic spreading directions are poorly represented beneath the Adriatic microplate, which provides support for the hypothesis of asymmetric Tethyan rifting as already proposed on a geologic basis (e.g., Lemoine et al. 1986; Manatschal and Müntener 2009; Malusà et al. 2015). In fact, asymmetric rifting implies that, during lithospheric extension, tectonite fabrics should be best developed within the Tethys oceanic lithosphere and the European subcontinental mantle but should not be expected in the Adriatic subcontinental mantle (Fig. 12b), in line with the results reported in Fig. 12a.

Finally, the low Vp anomaly region to the west of the Alpine and Apenninic slabs shows a continuous trend of fast-axis directions ( 3 in Fig. 12a) that follows the arc of the Western Alps down to the Ligurian coast, where this trend merges with a WNW-ESE trend of fast-axis directions already described in SE France by Barruol et al. (2004). This seismic anisotropy pattern has a clear asthenospheric origin. It shows different directions compared to Pn anisotropy that samples the shallow lithospheric mantle (Díaz et al. 2013) and azimuthal anisotropy from noise and surface waves that samples a maximum depth of 120-125 km (Fry et al. 2010; Zhu and Tromp 2013). Since its first detection, the anisotropy "trend 3" was interpreted as an effect of asthenospheric

This article is protected by copyright. All rights reserved. 
flow due to the eastward retreat of the Apenninic slab (Barruol et al. 2004; Lucente et al. 2006; Jolivet et al. 2009), an interpretation confirmed by the CIFALPS experiment (Salimbeni et al. 2018). This continuous trend of fast-axis directions provides additional evidence against the hypothesis of Alpine slab breakoff. In fact, slab breakoff would imply a mantle flow through the slab that should be revealed by slab-perpendicular fast-axis directions (Fig. 12d). These slabperpendicular fast axes are not observed in Fig. 12a.

\subsection{Contrasting origin of the low-velocity anomalies in the Alpine upper mantle}

The observed correspondence between the continuous trend of fast-axis directions and the low Vp anomaly in the European upper mantle provides pinpoints for further interpretation of the upper mantle structure beneath the Alpine region. This low Vp anomaly may either attest to the presence of fluids or have a thermal origin. The former hypothesis can be excluded in light of the location and the depth of the low Vp anomaly with respect to the nearby slabs (Figs. 10e, 11). On the other hand, a potential thermal origin may be related to asthenospheric upwelling, possibly due to the counterflow induced by Apenninic slab retreat in the absence of an adequate mass compensation by a toroidal mantle flow around the northern tip of the retreating slab (Salimbeni et al. 2018). An efficient toroidal mantle flow would compensate the effects of slab retreat on the adjoining mantle by transferring asthenospheric material from the rear of the Apenninic slab towards a supraslab position (Vignaroli et al. 2008; Faccenna and Becker 2010; Salimbeni et al. 2013). However, seismic anisotropy data are not supportive of an efficient toroidal flow beneath the Po Plain (Fig. 12a). Recent tomography models show no major gap in the slab structure between the Alps and the Apennines (Fig. 11), and the absence of enough space between the two slabs may preclude flow around the northern tip of the Apenninic slab during its rollback, with major implications for the asthenospheric mantle flow farther west. In fact, the absence of an efficient toroidal flow implies that Apenninic slab rollback may have induced not only a suction effect and an asthenospheric counterflow at the rear of the unbroken Western Alps slab (Barruol et al. 2004; Jolivet et al. 2009), but also a component of asthenospheric upwelling to compensate the lack of mantle material transferred from the rear to the front of the Apenninic slab (Salimbeni et al. 2018). Although the magnitude of mantle upwelling is probably much smaller than the magnitude of the horizontal component of the mantle flow (Fig. 12d), the vertical component associated with mantle flow may have led to a temperature increase in the upper mantle, which may explain the low Vp anomaly imaged by P-wave tomography (Zhao et al. 2016b).

The low Vp anomaly B located atop the Alpine slab beneath the Po Plain may instead attest to the impact of slab released fluids, as first suggested by Giacomuzzi et al. (2011). This topic has been recently addressed by Malusà et al. (2018), who combined geodynamic reconstructions with geophysical imaging and petrological modeling to reveal large-scale carbon processes associated with the complex slab configuration of the Alpine region. According to Malusà et al. (2018), the low-velocity anomaly in the upper mantle beneath the Po Plain would be generated by extraction of carbon-rich melts from the asthenosphere, favoured by the breakdown of slab carbonates and hydrous minerals after cold Alpine subduction. Carbonates and hydrous minerals (e.g., phengite) can escape breakdown if the geothermal gradient during subduction is sufficiently low (Fig. 13c) and can be dragged into the upper mantle by the downgoing slab (1 in Fig. 13c). After subduction, the slab is progressively thermally reequilibrated towards ambient mantle conditions, with a temperature increase ( 2 in Fig. 13c) that may promote dehydration reactions and carbonate breakdown. Consequent generation of carbon-rich supercritical fluids at the slab interface triggers melting in the overlying mantle wedge, with low density and low viscosity carbon-rich melts rising

This article is protected by copyright. All rights reserved. 
in the Adriatic asthenosphere (Fig. 13b) to be finally frozen at $\sim 180 \mathrm{~km}$ depth (3 in Fig. 13b), where the mantle geotherm crosses the carbonated hydrous peridotite solidus ( 3 in Fig. $13 \mathrm{c}$ ). This implies sequestration of carbon in the upper mantle without immediate release (Malusà et al. 2018).

The low-velocity anomalies A and B located on either side of the Alpine slab may thus have different origins, that is asthenospheric upwelling to the west (Zhao et al. 2016b; Salimbeni et al. 2018) and fluids released from the Alpine slab to the east (Malusà et al. 2018). This makes numerical modeling exercises applied to the analysis of sub-lithospheric mantle convection (e.g., Sternai et al. 2019) more challenging than expected, because the commonly assumed relationships between seismic velocity, temperature and rock density (e.g., Simmons et al. 2010) are not necessarily met. This may explain why both the tomography models of Lippitsch et al. (2003) and Zhao et al. (2016b), when analyzed in terms of mantle convection modeling (Sternai et al. 2019), point to positive dynamic uplift in the Po Plain that is at odds with observations. If not properly accounted for, the different origins of the different low-velocity anomalies in the Alpine region may preclude a reliable quantification of the contribution from mantle convection to the measured uplift rates (e.g., Serpelloni et al. 2013; Walpersdorf et al. 2015; Nocquet et al. 2016).

\section{Interpretive cross sections at lithospheric and upper-mantle scales}

Based on the geophysical constraints provided by the CIFALPS experiment, interpretive cross sections at the scale of the lithosphere and the upper mantle are shown in Fig. 13. In the southern Western Alps, the uppermost 20-25 km of the European lower plate consists of a mainly granitic upper crust and associated sedimentary cover (Fig. 13a). These upper crustal rocks rest on top of a relatively homogeneous lower crust, likely consisting of granulitic rocks of felsic to intermediate composition (Solarino et al. 2018). At depths $>40 \mathrm{~km}$ beneath the Alpine subduction wedge, the European lower crust is progressively eclogitized, but seismically distinguishable from the underlying mantle lithosphere down to depths of $\sim 75 \mathrm{~km}$ (Zhao et al. 2015; Solarino et al. 2018). The eastward-dipping European Moho is located at 30-40 km depth beneath the Southeast basin and the External zone, reaching $~ 75 \mathrm{~km}$ depth beneath the Dora-Maira and the western Po Plain (Zhao et al. 2015, 2020). The main NE-SW trending Moho step detected to the NW of the Belledonne and Mont Blanc massifs (Lu et al. 2018; Zhao et al. 2020) is not observed in the southern Western Alps, where the European Moho shows a more continuous profile (Fig. 13a). No deep seismicity is observed along the European Moho or along its continuation at depth, as expected since subduction is no longer active (Malusà et al. 2017) (Fig. 13b).

On the upper-plate side of the orogen, the mainly gneissic and anisotropic Adriatic upper crust is $10-15 \mathrm{~km}$ thick beneath the Po Plain and the Monferrato thrust sheets (Fig. 13a). At the western tip of the Adriatic upper plate, the westward pinching Adriatic lower crust has a more heterogeneous composition compared to the lower crust of the European plate, and locally includes granulitic metapelites and underplated gabbro (Solarino et al. 2018). The eastward-dipping Adriatic Moho is located at $\sim 30 \mathrm{~km}$ depth under the Monferrato and at much shallower depth of 10-15 km in correspondence with the former necking zone of the southern Tethyan margin (Zhao et al. 2015). In the Adriatic lithospheric mantle, the dry to partly serpentinized peridotites of the former necking zone are underthrust by the peridotites of the European lithospheric mantle (Zhao et al. 2020) (Fig. 13a).

The Alpine subduction wedge is apparently thicker in the northern Western Alps compared to the southern Western Alps (Zhao et al. 2020). In the southern Western Alps, the subduction wedge

This article is protected by copyright. All rights reserved. 
includes pervasively fractured Schistes lustrés and Briançonnais rocks of the doubly-vergent Frontal wedge, exposed beside (U)HP metaophiolites and poorly fractured granitic gneisses of the DoraMaira dome. A body of mantle-wedge rocks with variable degrees of serpentinization, ranging from $>90 \%$ in the uppermost part of the body to $<30 \%$ at depth $>30 \mathrm{~km}$, is inferred under the Dora-Maira at depths as shallow as $\sim 10 \mathrm{~km}$. Similar bodies are not imaged beneath the eclogitic domes exposed farther north (i.e., the Gran Paradiso and Monte Rosa domes) (Solarino et al. 2018; Zhao et al. 2020). The body of mantle-wedge rocks under the Dora-Maira is virtually aseismic (Eva et al. 2020), consistent with the fact that serpentinization promotes aseismic deformation. To the east, these mantle-wedge rocks are delimited by an active left-lateral fault in the lithospheric mantle (RivoliMarene deep fault, RMF in Fig. 13a) that is marked by the alignment of anomalously deep earthquake hypocentres (Malusà et al. 2017). Therefore, based on the cross section of Fig. 13a, three different types of mantle rocks may contribute to the Ivrea gravity anomaly in the southern Western Alps: (i) to the west, mantle-wedge rocks emplaced at shallow crustal depth syn or post exhumation of the Dora-Maira (U)HP rocks; (ii) to the east, dry to partly serpentinized peridotites exhumed along the former necking zone of the southern Tethyan margin; (iii) in between, mantle rocks of the Lanzo massif that underwent Alpine subduction and were later exhumed and accreted against the Adriatic upper plate when the Dora-Maira (U)HP rocks were still buried at mantle depths (e.g., Rubatto and Hermann 2001; Rubatto et al. 2008; Angiboust and Glodny 2020).

In the underlying subduction channel, slivers of eclogitic metasediments and other (U)HP rocks are documented starting from depths $\sim 40 \mathrm{~km}$ (Solarino et al. 2018). Serpentinites likely mark the subduction channel in the depth range between $\sim 45$ and $\sim 70 \mathrm{~km}$ (Zhao et al. 2020) and are replaced at greater depth by metasomatized mantle peridotites likely affected by infiltration of slab fluids. At either side of the Alpine subduction wedge, different tectonic styles characterize the lower and upper plate lithosphere. The former is cut by hinterland-dipping thrusts rooted in the Alpine subduction wedge, whereas the latter is cut by near-vertical faults (Fig. 13a).

At the upper-mantle scale (Fig. 13b), the CIFALPS results indicate that the lithosphereasthenosphere boundary is located at $\sim 110 \mathrm{~km}$ depth beneath the European foreland and is approximately parallel to the eastward dipping European Moho, which suggests a $\sim 110 \mathrm{~km}$ thick and eastward-dipping European lithosphere (Lyu et al. 2017). Beneath the Po Plain, the Adriatic lithosphere-asthenosphere boundary is located at $\sim 100 \mathrm{~km}$ depth (Malusà et al. 2018). The Western Alps slab is apparently continuous beneath the western Po Plain, possibly reaching 300 $\mathrm{km}$ in length (Zhao et al. 2016b). It includes not only European lithosphere, but also Tethys lithosphere and the lithosphere of the adjoining ocean-continent transition zone (OCT in Fig. 13b) (Malusà et al. 2018), all showing a tectonite fabric that is not documented in the Adriatic subcontinental mantle (Salimbeni et al. 2018). The asthenosphere at the rear of the Western Alps slab is affected by slab-parallel mantle flow likely triggered by Apenninic slab rollback (Barruol et al. 2004; Salimbeni et al. 2018). This flow may have induced weakening of the overlying Alpine slab (Fig. 13b). In a supraslab position, independent circulations may have controlled slab-to-mantle exchanges at different depth ranges, with cold subduction possibly favouring long-term sequestration of carbon in the asthenospheric mantle (Malusà et al. 2018).

\section{Geodynamic evolution and progressive development of the deep Alpine structure}

The deep Alpine structure revealed by the CIFALPS experiments was acquired during different steps of the complex evolution of the Adria-Europe plate boundary zone. It results from a combination of pre-Alpine tectonic inheritance, impact of Tethyan rifting, accommodation of

This article is protected by copyright. All rights reserved. 
Adria-Europe convergence by Alpine subduction, and activity of nearby subduction zones after Alpine subduction cessation and continent-continent collision.

\subsection{Pre-Alpine inheritance and Tethyan rifting}

Tethyan rifting marking the onset of the Alpine tectonic cycle likely reactivated former Paleozoic suture zones (Guillot et al. 2009b; Bergomi et al. 2017). We infer that the different composition of the upper and lower crust in the Adriatic and European plates may be partly inherited from different pre-Alpine evolutions (Solarino et al. 2018). Many Variscan lineaments were re-activated during the opening of the Alpine Tethys (Malusà et al. 2016a), and a Variscan inheritance may be also suggested for the Moho step detected by Lu et al. (2018) and Zhao et al. (2020) to the NW of the Belledonne and Mont Blanc massifs. During the opening of the Alpine Tethys, the Ivrea mantle rocks were exhumed to shallow crustal depths in the necking zone of the southern Tethyan margin (Manatschal and Müntener 2009). This process may have also led to the westward thinning of the Adriatic lower crust along the CIFALPS transect (Fig. 13a). Subcontinental mantle rocks were exhumed to the Tethys seafloor at this stage and underwent serpentinization by seafloor hydrothermal activity and seawater alteration (Deschamps et al. 2013). Due to the low spreading rates characterizing the Alpine Tethys, serpentinization may have occurred over a thickness of 2-4 km reaching extents of 70-80\% (e.g., Rouméjon and Cannat 2014). During lithospheric extension, mantle peridotites now belonging to the Alpine slab likely acquired a tectonite fabric controlled by the direction of Jurassic spreading. All of these features were already present during the early stages of oblique Alpine subduction (Fig. 14a) and may have controlled the propagation of deformation during subduction and subsequent continent-continent collision.

\subsection{Alpine subduction and exhumation}

During Alpine subduction, abyssal serpentinites formed at the Tethys seafloor were either stacked in the subduction wedge or dragged into the Alpine subduction channel. Subducted European lower crust underwent progressive eclogitization, whereas upper-crust slivers were stacked in the subduction wedge (Zhao et al. 2015; Solarino et al. 2018). Aqueous fluids released from the slab at sub-arc depths promoted serpentinization in the subduction wedge and along the plate interface above the subduction channel. The resulting serpentinized plate interface may have favoured the subduction of European continental lithosphere and the formation of continental (U)HP rocks (Zhao et al. 2020). Northward Adria motion in the late Eocene and associated localized divergence in the western segment of the Alpine subduction zone may have triggered, according to Malusà et al. (2011, 2015), the fast exhumation of buoyant (U)HP rocks now exposed in the Dora-Maira massif (Fig. 14b). Along the CIFALPS transect, serpentinized mantle-wedge rocks may have followed the exhumation path of buoyant (U)HP rocks towards the Earth's surface to be finally emplaced beneath the Dora-Maira dome (Liao et al. 2018b; Solarino et al. 2018), also favouring the final exhumation of continental (U)HP rocks across the upper crust where eclogitized continental-crust rocks may become neutrally buoyant (Schwartz et al. 2001). During transtension, subducted abyssal and deeper mantle-wedge serpentinites likely moved upwards along the subduction channel, which became much thicker compared to the previous stages of plate convergence (Liao et al. 2018b; Zhao et al. 2020). Subducted abyssal serpentinites may also form the uppermost part of the serpentinized mantle wedge beneath the Dora-Maira, where the degree of serpentinization of the precursor peridotite may reach as high as $90 \%$. The exhumed mantlewedge rocks and the Ivrea mantle rocks were thus juxtaposed at shallow crustal levels in the late Eocene (Solarino et al. 2018). In the northern Western Alps, mantle-wedge exhumation was likely

This article is protected by copyright. All rights reserved. 
precluded by the lower amount of divergence due to the coeval indentation of Adria beneath the Central Alps (Liao et al. 2018b), also associated with back-folding of (U)HP domes (Keller et al. 2005) and backthrusting of Southalpine units (Zanchetta et al. 2015). At a broader scale, the interaction between the Dinaric slab and the Alpine slab may have led to the formation, beneath the Giudicarie Fault, of a vertical tear in the Alpine slab (Zhao et al. 2016b) with major implications for the development of Periadriatic magmatism (Ji et al. 2019).

\subsection{Post-subduction evolution}

After cessation of Alpine subduction, Neogene retreat of the Apenninic slab likely induced a counterflow in the asthenospheric mantle at the rear of the Alpine slab (Barruol et al. 2004; Salimbeni et al. 2018). Interaction between the northward shifting Apenninic slab and the SWdipping Alpine slab may have controlled the location of the northern tip of the scissor-type Ligurian-Provençal basin opening in the Apenninic backarc (Malusà et al. 2016b). In the southern Western Alps, the northward motion of the Adriatic microplate was accommodated by strike-slip activity along the Rivoli-Marene deep fault (Eva et al. 2015), located at the eastern boundary of the exhumed mantle wedge. In the Adriatic mantle lithosphere, earthquakes occurrence down to depths of $\sim 75 \mathrm{~km}$ indicates that geothermal gradients in the upper plate have remained low $(<8$ ${ }^{\circ} \mathrm{C} / \mathrm{km}$ ) and substantially similar to the gradients experienced by the Dora-Maira (U)HP rocks during their prograde path (Fig. 13c) (Malusà et al. 2017). Thermal reequilibration of the Alpine slab towards ambient mantle conditions promoted the generation of carbon-rich supercritical fluids and carbon storage in the Alpine upper mantle. The Moho step in the European foreland was possibly reactivated as a result of flexural loading by the leading edge of the Adriatic microplate (Fig. 14c). During the final collision stages (Fig. 14d), the Ivrea mantle acted as a rigid buttress constraining crustal shortening to the lower plate, which may have favoured the formation of the Jura fold-and-thrust belt to the NW of the Alps (Liao et al. 2018a), whereas the eastward propagation of the asthenospheric counterflow towards the Ligurian Alps led to the northward tilting of the Tertiary Piedmont basin succession.

\section{Conclusions and open questions}

The CIFALPS experiment has allowed a major step forward in our understanding of the deep structure of the southern Western Alps and of the broader Alpine region more generally. Major tectonic features at the scale of the lithosphere and the upper mantle are now constrained in a compelling way by the integration of independent tomographic methods that exploit different information from high-resolution seismic data sets. The application of a wide range of tomographic methods to the analysis of a single fossil subduction zone and the joint interpretation with geological and petrophysical data make the CIFALPS experiment a reference case that could be exported to other study areas. Major results include:

(i) the first seismic evidence of European crust subducted into the Adriatic upper mantle, right beneath the place where coesite was first recognized in continental (U)HP rocks in the Alps;

(ii) evidence of the major involvement of the mantle wedge during crucial steps of (U)HP rock exhumation;

(iii) the first high-resolution image of a fossil subduction channel providing evidence of a serpentinized plate interface that favours continental subduction;

(iv) evidence of a continuous slab beneath the Western and Central Alps, ruling out the classic hypothesis of slab breakoff magmatism right in the place where the slab-

This article is protected by copyright. All rights reserved. 
breakoff model was first proposed; however, this does not exclude that slab breakoff magmatism may have affected other regions on Earth;

(v) evidence of a polyphase development of anisotropic mantle fabrics, either representing active mantle flows inducing localized weakening of the overlying lithosphere, or fossil fabrics inherited from previous rifting stages.

Open questions remain to be addressed, concerning for example the upper mantle structure at the transition between the different slabs imaged beneath the broader Alpine region, the impact of slab-parallel mantle flow on the overlying lithosphere, or the lateral continuity of the finest geologic structures recognized in the fossil subduction channel along the CIFALPS transect. New constraints to the complicated slab structure at the transition between the Eastern Alps and the Dinarides are expected from the Swath-D AlpArray complementary experiment (Heit et al. 2018). Additional insights on the deep tectonic structure of the western Alpine region will be provided by the CIFALPS-2 experiment, a passive seismic survey that crosscuts the northern Western Alps across the Gran Paradiso massifs and the Ivrea body, reaching as far south as the Ligurian Sea.

\section{Acknowledgments, Samples, and Data}

The authors have no conflict of interest to declare. Data is available through Zhao et al. 2015, Zhao et al. 2016b, Lyu et al. 2017, Salimbeni et al. 2018, Solarino et al. 2018, Sun et al. 2019 and Zhao et al. 2020. We thank Rixiang Zhu, Yi Chen, Qin Wang and Helle Pedersen for support and fruitful discussions. This research was supported by CAS program (GJHZ1776), NSFC (grants no. 41625016, 41888101, 91755000), National Key R\&D Program of China (grant no. 2017YFC0601206), Agence Nationale de la Recherche (contract ANR-15- CE31-0015) and Labex OSUG@2020 (Investissement d'Avenir, ANR-10-LABX-56).

\section{References}

Agard, P., Monié, P., Jolivet, L., \& Goffé, B. (2002). Exhumation of the Schistes Lustrés complex: in situ laser probe 40Ar/39Ar constraints and implications for the Western Alps. Journal of metamorphic Geology, 20(6), 599-618.

Agard, P., Yamato, P., Jolivet, L., \& Burov, E. (2009). Exhumation of oceanic blueschists and eclogites in subduction zones: timing and mechanisms. Earth-Science Reviews, 92(1-2), 53-79.

Amato, A., Margheriti, L., Azzara, R., Basili, A., Chiarabba, C., Ciaccio, M. G., ... \& Nostro, C. (1998). Passive seismology and deep structure in central Italy. In Geodynamics of Lithosphere \& Earth's Mantle (pp. 479-493). Birkhäuser, Basel.

Angiboust, S. and Glodny, J. (2020) Exhumation of eclogitic ophiolitic nappes in the W. Alps: New age data and implications for crustal wedge dynamics. Lithos, 353, 105374

Argand, E. (1911). I. Les nappes de recouvrement des Alpes pennines et leurs prolongements structuraux (No. 31-33). In Kommission bei A. Francke (vorm. Schmid \& Francke).

Argand, E. (1916). Sur l'arc des Alpes occidentales. G. Bridel.

Audet, P. (2013). Seismic anisotropy of subducting oceanic uppermost mantle from fossil spreading. Geophysical research letters, 40(1), 173-177.

This article is protected by copyright. All rights reserved. 
Baccheschi, P., Salimbeni, S., Solarino, S., Eva, E., Malusà, M. G., Guillot, S., ... \& Margheriti, L. (2019). Anisotropic structure beneath the Western Alps as inferred by the analysis of anomalously deep earthquakes. Geophysical Research Abstracts 21, EGU2019-16944.

Barfety, J. C., Lemoine. M., Mercier, D., Polino, R., Nievergelt, P., Bertrand, J., Dumont, T., Amaudric du Chaffaut, S., Pecher, A., \& Monjuvent, G. (1996). Carte Géologique de France (1/50.000), Feuille Briançon (823), 180 p., Bur. de Rech. Geol. et Min., Orléans, France.

Barruol, G., Deschamps, A., \& Coutant, O. (2004). Mapping upper mantle anisotropy beneath SE France by SKS splitting indicates Neogene asthenospheric flow induced by Apenninic slab roll-back and deflected by the deep Alpine roots. Tectonophysics, 394(1-2), 125138.

Barruol, G., Bonnin, M., Pedersen, H., Bokelmann, G. H., \& Tiberi, C. (2011). Belt-parallel mantle flow beneath a halted continental collision: The Western Alps. Earth and Planetary Science Letters, 302(3-4), 429-438.

Bellahsen, N., Mouthereau, F., Boutoux, A., Bellanger, M., Lacombe, O., Jolivet, L., \& Rolland, Y. (2014). Collision kinematics in the western external Alps. Tectonics, 33(6), 10551088.

Beller, S., Monteiller, V., Operto, S., Nolet, G., Paul, A., \& Zhao, L. (2018). Lithospheric architecture of the South-Western Alps revealed by multiparameter teleseismic fullwaveform inversion. Geophysical Journal International, 212(2), 1369-1388.

Beltrando, M., Compagnoni, R., \& Lombardo, B. (2010). (Ultra-) High-pressure metamorphism and orogenesis: an Alpine perspective. Gondwana Research, 18(1), 147-166.

Bergomi, M. A., Zanchetta, S., \& Tunesi, A. (2015). The Tertiary dike magmatism in the Southern Alps: geochronological data and geodynamic significance. International Journal of Earth Sciences, 104(2), 449-473.

Bergomi, M. A., Dal Piaz, G. V., Malusà, M. G., Monopoli, B., \& Tunesi, A. (2017). The Grand St Bernard $\square$ Briançonnais nappe system and the Paleozoic inheritance of the Western Alps unraveled by zircon $\mathrm{U} \square \mathrm{Pb}$ dating. Tectonics, 36(12), 2950-2972.

Bernoulli D., Caron C., Homewood P., Kälin O., \& Van Stujvenberg J. (1979). Evolution of continental margins in the Alps. Schweiz. Mineral. Petrogr. Mitt., 59, 165-170.

Bertrand, J. M., Guillot, F., Leterrier, J., Perruchot, M. P., Aillères, L., \& Macaudière, J. (1998). Granitoïdes de la Zone Houillère Briançonnaise en Savoie et en Val d'Aoste (Alpes Occidentales): géologie et géochronologie U-Pb sur zircon. Geodinamica Acta, 11(1), 3349.

Béthoux, N., Sue, C., Paul, A., Virieux, J., Fréchet, J., Thouvenot, F., \& Cattaneo, M. (2007). Local tomography and focal mechanisms in the South-western Alps: comparison of methods and tectonic implications. Tectonophysics 432, 1-19.

Bezacier, L., Reynard, B., Bass, J. D., Wang, J., \& Mainprice, D. (2010). Elasticity of glaucophane, seismic velocities and anisotropy of the subducted oceanic crust. Tectonophysics, 494(3-4), 201-210.

This article is protected by copyright. All rights reserved. 
Bezacier, L., Reynard, B., Cardon, H., Montagnac, G., \& Bass, J. D. (2013). High $\square$ pressure elasticity of serpentine and seismic properties of the hydrated mantle wedge. Journal of Geophysical Research: Solid Earth, 118(2), 527-535.

Bigi, G., Cosentino, D., Parotto, M., Sartori, R., \& Scandone, P. (1990). Structural model of Italy and gravity map. Sheets 1-9, 1:500.000. Progetto Finalizzato Geodinamica C.N.R. Quaderni Ricerca Scientifica, 114 (3).

Bistacchi, A., Dal Piaz, G., Massironi, M., Zattin, M., \& Balestrieri, M. (2001). The AostaRanzola extensional fault system and Oligocene-Present evolution of the AustroalpinePenninic wedge in the northwestern Alps. International Journal of Earth Sciences, 90(3), 654-667.

Bocquet, J. (1971). Cartes de répartition de quelques minéraux du métamorphisme alpin dans les Alpes franco italiennes. Eclogae geol. Helv. 64, 71-103.

Bocquet, J., Delaloye, M., Hunziker, J. C., \& Krummenacher, D. (1974). K-Ar and Rb-Sr dating of blue amphiboles, micas, and associated minerals from the Western Alps. Contributions to Mineralogy and Petrology, 47(1), 7-26.

Bodin, T., Sambridge, M., Rawlinson, N., \& Arroucau, P. (2012a). Transdimensional tomography with unknown data noise. Geophysical Journal International, 189(3), 15361556.

Bodin, T., Sambridge, M., Tkalčić, H., Arroucau, P., Gallagher, K., \& Rawlinson, N. (2012b). Transdimensional inversion of receiver functions and surface wave dispersion. Journal of Geophysical Research: Solid Earth, 117(B2).

Bodin, T., Yuan, H., \& Romanowicz, B. (2014). Inversion of receiver functions without deconvolution-application to the Indian craton. Geophysical Journal International, 196(2), 1025-1033.

Bose, K., \& Ganguly, J. (1995). Experimental and theoretical studies of the stabilities of talc, antigorite and phase A at high pressures with applications to subduction processes. Earth and Planetary Science Letters, 136(3-4), 109-121.

Boudier, F. (1978). Structure and petrology of the Lanzo peridotite massif (Piedmont Alps). Geological Society of America Bulletin, 89(10), 1574-1591.

Brandmayr, E., Blagoeva, R., Zuri, M., Romanelli, F., Doglioni, C., \& Panza, G. F. (2010). The lithosphere in Italy: structure and seismicity (No. IC--2010/020). Journal Virtual Explorer 36, https://doi.org/10.3809/jvirtex.2010.00224

Brouwer, F., Vissers, R., \& Lamb, W. (2002). Structure and metamorphism of the Gran Paradiso massif, western Alps, Italy. Contributions to Mineralogy and Petrology, 143(4), 450-470.

Brouwer, F. M., Van De Zedde, D. M. A., Wortel, M. J. R., \& Vissers, R. L. M. (2004). Lateorogenic heating during exhumation: Alpine PTt trajectories and thermomechanical models. Earth and Planetary Science Letters, 220(1-2), 185-199.

Brownlee, S. J., Hacker, B. R., Salisbury, M., Seward, G., Little, T. A., Baldwin, S. L., \& Abers, G. A. (2011). Predicted velocity and density structure of the exhuming Papua New Guinea ultrahigh $\square$ pressure terrane. Journal of Geophysical Research: Solid Earth, 116(B8).

This article is protected by copyright. All rights reserved. 
Caby, R. (1975). Geodynamic implications of transverse folding in the Western Alps for the Alpine fold belt. Nature, 256(5513), 114-117.

Caby, R. (1996). Low-angle extrusion of high-pressure rocks and the balance between outward and inward displacements of Middle Penninic units in the western Alps. Eclogae Geologicae Helvetiae, 89(1), 229-268.

Campillo, M., \& Paul, A. (2003). Long-range correlations in the diffuse seismic coda. Science, 299(5606), 547-549.

Capponi, G., \& Crispini, L. (2002). Structural and metamorphic signature of alpine tectonics in the Voltri Massif (Ligurian Alps, North-Western Italy). Eclogae Geologicae Helvetiae, 95(1), 31-42.

Carminati, E., Wortel, M. J. R., Spakman, W., \& Sabadini, R. (1998). The role of slab detachment processes in the opening of the western-central Mediterranean basins: some geological and geophysical evidence. Earth and Planetary Science Letters, 160(3-4), 651665 .

Carminati, E., \& Doglioni, C. (2012). Alps vs. Apennines: the paradigm of a tectonically asymmetric Earth. Earth-Science Reviews, 112(1-2), 67-96.

Carminati, E., Lustrino, M., \& Doglioni, C. (2012). Geodynamic evolution of the central and western Mediterranean: Tectonics vs. igneous petrology constraints. Tectonophysics, 579, 173-192.

Cattaneo, M., Augliera, P., Parolai, S., \& Spallarossa, D. (1999). Anomalously deep earthquakes in northwestern Italy. Journal of seismology, 3(4), 421-435.

Chevrot, S., Villaseñor, A., Sylvander, M., Benahmed, S., Beucler, E., Cougoulat, G., ... \& Grimaud, F. (2014). High $\square$ resolution imaging of the Pyrenees and Massif Central from the data of the PYROPE and IBERARRAY portable array deployments. Journal of Geophysical Research: Solid Earth, 119(8), 6399-6420.

Chopin, C. (1984). Coesite and pure pyrope in high-grade blueschists of the Western Alps: a first record and some consequences. Contributions to Mineralogy and Petrology, 86(2), 107118.

Chopin, C., Henry, C., \& Michard, A. (1991). Geology and petrology of the coesite-bearing terrain, Dora Maira massif, Western Alps. European Journal of Mineralogy, 3(2), 263291.

Christensen, N.I. (1989). Seismic velocities. In: Carmichael, R.S. (Ed.), Practical Handbook of Physical Properties of Rocks and Minerals. CRC Press, Boca Raton, p. 741.

Closs, H., Labrouste, Y. (Eds.), 1963. Rechèrches séismologiques dans les Alpes occidentales au moyen de grandes explosions en 1956, 1958 et 1960. Mem. Coll. Année Geophys. Int. 12-2. CNRS, Paris (241 pp.).

Cotte, N., Pedersen, H. A., \& TOR Working Group. (2002). Sharp contrast in lithospheric structure across the Sorgenfrei-Tornquist Zone as inferred by Rayleigh wave analysis of TOR1 project data. Tectonophysics, 360(1-4), 75-88.

This article is protected by copyright. All rights reserved. 
Coward, M., \& Dietrich, D. (1989). Alpine tectonics—an overview. Geological Society, London, Special Publications, 45(1), 1-29.

Dal Piaz, G. V. (2001). History of tectonic interpretations of the Alps. Journal of geodynamics, 32(1-2), 99-114.

Dal Piaz, G. V., \& Ernst, W. G. (1978). Areal geology and petrology of eclogites and associated metabasites of the Piemonte ophiolite nappe, breuil—st. Jacques area, Italian Western Alps. Tectonophysics, 51(1-2), 99-126.

Dal Piaz, G. V., \& Lombardo, B. (1986). Early Alpine eclogite metamorphism in the Penninic Monte Rosa-Gran Paradiso basement nappes of the northwestern Alps. Geol. Soc. Am. Mem, 164, 249-265.

Dal Piaz, G. V., Bistacchi, A., \& Massironi, M. (2003). Geological outline of the Alps. Episodes, 26(3), 175-180.

Dal Zilio, L. (2020). Slab rollback Orogeny model for the evolution of the Central Alps: SeismoThermo-Mechanical test. In Cross-Scale Modeling of Mountain Building and the Seismic Cycle: From Alps to Himalaya (pp. 45-66). Springer, Cham.

Dando, B. D. E., Stuart, G. W., Houseman, G. A., Hegedüs, E., Brückl, E., \& Radovanović, S. (2011). Teleseismic tomography of the mantle in the Carpathian-Pannonian region of central Europe. Geophysical Journal International, 186(1), 11-31.

Dasgupta, R., \& Hirschmann, M. M. (2006). Melting in the Earth's deep upper mantle caused by carbon dioxide. Nature, 440(7084), 659-662.

Davies, J. H., \& von Blanckenburg, F. (1995). Slab breakoff: a model of lithosphere detachment and its test in the magmatism and deformation of collisional orogens. Earth and Planetary Science Letters, 129(1-4), 85-102.

De Paoli, M. C., Clarke, G. L., \& Daczko, N. R. (2012). Mineral equilibria modeling of the granulite-eclogite transition: effects of whole-rock composition on metamorphic facies type-assemblages. Journal of Petrology, 53(5), 949-970.

Deschamps, F., Godard, M., Guillot, S., \& Hattori, K. (2013). Geochemistry of subduction zone serpentinites: A review. Lithos, 178, 96-127.

Deville, E., Fudral, S., Lagabrielle, Y., Marthaler, M., \& Sartori, M. (1992). From oceanic closure to continental collision: A synthesis of the" Schistes lustrés" metamorphic complex of the Western Alps. Geological Society of America Bulletin, 104(2), 127-139.

Dewey, J. F., Pitman, W. C., Ryan, W. B., \& Bonnin, J. (1973). Plate tectonics and the evolution of the Alpine system. Geological society of America bulletin, 84(10), 3137-3180.

Dewey, J. F., Helman, M. L., Knott, S. D., Turco, E., \& Hutton, D. H. W. (1989). Kinematics of the western Mediterranean. Geological Society, London, Special Publications, 45(1), 265-283.

Diaz, J., Gil, A., \& Gallart, J. (2013). Uppermost mantle seismic velocity and anisotropy in the Euro-Mediterranean region from Pn and Sn tomography. Geophysical Journal International, 192(1), 310-325.

This article is protected by copyright. All rights reserved. 
Diehl, T., Husen, S., Kissling, E., \& Deichmann, N. (2009). High-resolution 3-DP-wave model of the Alpine crust. Geophysical Journal International, 179(2), 1133-1147.

Dolomieu de, D.G. (1791). Sur un genre de pierres calcaires très peu effervescentes avec les acides et phosphorescentes par la collision. Journal de physique, t. XXXIX.

Dost, B. (1990). Upper mantle structure under western Europe from fundamental and higher mode surface waves using the NARS array. Geophysical Journal International, 100(1), 131-151.

Dumont, T., Simon $\square$ Labric, T., Authemayou, C., \& Heymes, T. (2011). Lateral termination of the north $\square$ directed Alpine orogeny and onset of westward escape in the Western Alpine arc: Structural and sedimentary evidence from the external zone. Tectonics, 30(5).

Dumont T., Schwartz S., Guillot S., Simon-Labric T., Tricart P., \& Jourdan S. (2012). Structural and sedimentary records of the Oligocene revolution in the Western Alps. Journal of Geodynamics, 56-57, 18-38

Dziewonski, A. M., \& Anderson, D. L. (1981). Preliminary reference Earth model. Physics of the earth and planetary interiors, 25(4), 297-356.

Ernst, W. G. (1971). Metamorphic zonations on presumably subducted lithospheric plates from Japan, California and the Alps. Contributions to Mineralogy and Petrology, 34(1), 43-59.

Ernst, W. G. (1973). Interpretative synthesis of metamorphism in the Alps. Geological Society of America Bulletin, 84(6), 2053-2078.

Eva, E., Malusà, M. G., \& Solarino, S. (2015). A seismotectonic picture of the inner southern Western Alps based on the analysis of anomalously deep earthquakes. Tectonophysics, 661, 190-199.

Eva, E., Malusà, M. G., \& Solarino, S. (2020). Seismotectonics at the transition between opposite $\square$ dipping slabs (western Alpine region). Tectonics, 39, e2020TC006086, 1-20. https://doi.org/10.1029/2020TC006086

Evans, B. W. (2004). The serpentinite multisystem revisited: chrysotile is metastable. International Geology Review, 46(6), 479-506.

Ewing, T. A., Rubatto, D., \& Hermann, J. (2014). Hafnium isotopes and Zr/Hf of rutile and zircon from lower crustal metapelites (Ivrea-Verbano Zone, Italy): implications for chemical differentiation of the crust. Earth and Planetary Science Letters, 389, 106-118.

Faccenna, C., \& Becker, T. W. (2010). Shaping mobile belts by small-scale convection. Nature, 465(7298), 602-605.

Faccenna, C., Becker, T. W., Auer, L., Billi, A., Boschi, L., Brun, J. P., ... \& Piromallo, C. (2014). Mantle dynamics in the Mediterranean. Reviews of Geophysics, 52(3), 283-332.

Fantoni, R., \& Franciosi, R. (2010). Tectono-sedimentary setting of the Po Plain and Adriatic foreland. Rendiconti Lincei, 21(1), 197-209.

Federico, L., Capponi, G., Crispini, L., \& Scambelluri, M. (2004). Exhumation of alpine highpressure rocks: insights from petrology of eclogite clasts in the Tertiary Piedmontese basin (Ligurian Alps, Italy). Lithos, 74(1-2), 21-40.

This article is protected by copyright. All rights reserved. 
Ferrara, G., Hirt, B., Jäger, E., \& Niggli, E. (1962). Rb-Sr and U-Pb age determinations on the pegmatite of I Mondei (Penninic Camughera-Moncucco-Complex, Italian Alps and some gneisses from the neighborhood). Eclogae Geologicae Helvetiae, 55.

Forcella, F., A. Mottana, \& G. Pasquarè (1973). Il massiccio cristallino interno di Valosio (Gruppo di Voltri, Provincia di Alessandria). Mem. Soc. Geol. Ital., 12, 485-528.

Fox, M., Herman, F., Kissling, E., \& Willett, S. D. (2015). Rapid exhumation in the Western Alps driven by slab detachment and glacial erosion. Geology, 43(5), 379-382.

Frei, W., Heitzmann, P., \& Lehner, P. (1990). Swiss NFP-20 research program of the deep structure of the Alps. Mémoires de la Société géologique de France (1833), 156, 29-46.

Frey, M., Hunziker, J. C., Frank, W., Bocquet, J., Dal Piaz, G. V., Jager, E., \& Niggli, E. (1974). Alpine metamorphism of the Alps: A review. Schweiz. Mineral. Petrogr. Mitt, 54, $247-$ 290.

Fry, B., Deschamps, F., Kissling, E., Stehly, L., \& Giardini, D. (2010). Layered azimuthal anisotropy of Rayleigh wave phase velocities in the European Alpine lithosphere inferred from ambient noise. Earth and Planetary Science Letters, 297(1-2), 95-102.

Gabudianu Radulescu, I., Rubatto, D., Gregory, C., \& Compagnoni, R. (2009). The age of HP metamorphism in the Gran Paradiso Massif, Western Alps: a petrological and geochronological study of "silvery micaschists". Lithos, 110(1-4), 95-108.

Ganne, J., Bertrand, J. M., Fudral, S., Marquer, D., \& Vidal, O. (2007). Structural and metamorphic evolution of the Ambin massif (western Alps): toward a new alternative exhumation model for the Brianconnais domain. Bulletin de la Société Géologique de France, 178(6), 437-458.

Garzanti, E., Radeff, G., \& Malusà, M. G. (2018). Slab breakoff: A critical appraisal of a geological theory as applied in space and time. Earth-Science Reviews, 177, 303-319.

Geissler, W. H., Sodoudi, F., \& Kind, R. (2010). Thickness of the central and eastern European lithosphere as seen by $\mathrm{S}$ receiver functions. Geophysical Journal International, 181(2), 604-634.

Giacomuzzi, G., Chiarabba, C., \& De Gori, P. (2011). Linking the Alps and Apennines subduction systems: new constraints revealed by high-resolution teleseismic tomography. Earth and Planetary Science Letters, 301(3-4), 531-543.

Goffé, B., Bousquet, R., Henry, P., \& Le Pichon, X. (2003). Effect of the chemical composition of the crust on the metamorphic evolution of orogenic wedges. Journal of metamorphic geology, 21(2), 123-141.

Grassi, D., \& Schmidt, M. W. (2011a). The melting of carbonated pelites from 70 to $700 \mathrm{~km}$ depth. Journal of Petrology, 52(4), 765-789.

Grassi, D., \& Schmidt, M. W. (2011b). Melting of carbonated pelites at 8-13 GPa: generating Krich carbonatites for mantle metasomatism. Contributions to Mineralogy and Petrology, 162(1), 169-191.

This article is protected by copyright. All rights reserved. 
Green, D. H., Hibberson, W. O., Rosenthal, A., Kovács, I., Yaxley, G. M., Falloon, T. J., \& Brink, F. (2014). Experimental study of the influence of water on melting and phase assemblages in the upper mantle. Journal of Petrology, 55(10), 2067-2096.

Groppo, C., Beltrando, M., \& Compagnoni, R. (2009). The P-T path of the ultra $\square$ high pressure Lago di Cignana and adjoining high $\square$ pressure meta $\square$ ophiolitic units: insights into the evolution of the subducting Tethyan slab. Journal of Metamorphic Geology, 27(3), 207231.

Groppo, C., Ferrando, S., Gilio, M., Botta, S., Nosenzo, F., Balestro, G., ... \& Rolfo, F. (2019). What's in the sandwich? New P-T constraints for the (U) HP nappe stack of southern Dora-Maira Massif (Western Alps). European Journal of Mineralogy, 31(4), 665-683.

Groupe de Recherche Géofrance 3D, 1997. Géofrance 3D: l'imagerie géologique et géophysique du sous-sol de la France, Mém. Soc. Géol. France, 172, 53-71.

Guillot, S., Hattori, K., Agard, P., Schwartz, S., \& Vidal, O. (2009a). Exhumation processes in oceanic and continental subduction contexts: a review. In Subduction zone geodynamics (pp. 175-205). Springer, Berlin, Heidelberg.

Guillot, S., di Paola, S., Ménot, R. P., Ledru, P., Spalla, M. I., Gosso, G., \& Schwartz, S. (2009b). Suture zones and importance of strike-slip faulting for Variscan geodynamic reconstructions of the External Crystalline Massifs of the western Alps. Bulletin de la Société géologique de France, 180(6), 483-500.

Hacker, B. R., \& Abers, G. A. (2004). Subduction Factory 3: An Excel worksheet and macro for calculating the densities, seismic wave speeds, and $\mathrm{H} 2 \mathrm{O}$ contents of minerals and rocks at pressure and temperature. Geochemistry, Geophysics, Geosystems, 5(1).

Hacker, B. R., Abers, G. A., \& Peacock, S. M. (2003). Subduction factory 1. Theoretical mineralogy, densities, seismic wave speeds, and H2O contents. Journal of Geophysical Research: Solid Earth, 108(B1).

Hacker, B. R., Kelemen, P. B., \& Behn, M. D. (2015). Continental lower crust. Annual Review of Earth and Planetary Sciences, 43, 167-205.

Handy, M. R., Schmid, S. M., Bousquet, R., Kissling, E., \& Bernoulli, D. (2010). Reconciling plate-tectonic reconstructions of Alpine Tethys with the geological-geophysical record of spreading and subduction in the Alps. Earth-Science Reviews, 102(3-4), 121-158.

Handy, M. R., Ustaszewski, K., \& Kissling, E. (2015). Reconstructing the Alps-CarpathiansDinarides as a key to understanding switches in subduction polarity, slab gaps and surface motion. International Journal of Earth Sciences, 104(1), 1-26.

Hawkesworth, C. J., Waters, D. J., \& Bickle, M. J. (1975). Plate tectonics in the Eastern Alps. Earth and Planetary Science Letters, 24(3), 405-413.

Hearn, T. M. (1999). Uppermost mantle velocities and anisotropy beneath Europe. Journal of Geophysical Research: Solid Earth, 104(B7), 15123-15139.

Heit, B., Weber, M., Haberland, C., Tilmann, F., Hemmleb, S., Schwarz, S., ... \& Pesaresi, D. (2018). The AlpArray SWATH-D experiment-A dense seismic array in the Central, Eastern and Southern Alps. Geophysical Research Abstracts 20, EGU2018-11509.

This article is protected by copyright. All rights reserved. 
Henry, C., Michard, A., \& Chopin, C. (1993). Geometry and structural evolution of ultra-highpressure and high-pressure rocks from the Dora-Maira massif, Western Alps, Italy. Journal of Structural Geology, 15, 965-965.

Hermann, J., Müntener, O., \& Scambelluri, M. (2000). The importance of serpentinite mylonites for subduction and exhumation of oceanic crust. Tectonophysics, 327(3-4), 225-238.

Hetényi, G., Cattin, R., Brunet, F., Bollinger, L., Vergne, J., Nábělek, J. L., \& Diament, M. (2007). Density distribution of the India plate beneath the Tibetan plateau: Geophysical and petrological constraints on the kinetics of lower-crustal eclogitization. Earth and Planetary Science Letters, 264(1-2), 226-244.

Hetényi, G., Molinari, I., Clinton, J., Bokelmann, G., Bondár, I., Crawford, W. C., ... \& Giardini, D. (2018). The AlpArray seismic network: a large-scale European experiment to image the Alpine Orogen. Surveys in geophysics, 39(5), 1009-1033.

Hilairet, N., Daniel, I., \& Reynard, B. (2006). Equation of state of antigorite, stability field of serpentines, and seismicity in subduction zones. Geophysical Research Letters, 33(2).

Hilairet, N., Reynard, B., Wang, Y., Daniel, I., Merkel, S., Nishiyama, N., \& Petitgirard, S. (2007). High-pressure creep of serpentine, interseismic deformation, and initiation of subduction. Science, 318(5858), 1910-1913.

Hirschmann, M. M. (2000). Mantle solidus: Experimental constraints and the effects of peridotite composition. Geochemistry, Geophysics, Geosystems, 1(10).

Hoogerduijn Strating, E., Rampone, E., Piccardo, G. B., Drury, M. R., \& Vissers, R. L. M. (1993). Subsolidus emplacement of mantle peridotites during incipient oceanic rifting and opening of the Mesozoic Tethys (Voltri Massif, NW Italy). Journal of Petrology, 34(5), 901-927.

Hua, Y., Zhao, D., \& Xu, Y. (2017). P wave anisotropic tomography of the Alps. Journal of Geophysical Research: Solid Earth, 122(6), 4509-4528.

Jamieson, R.A., \& Beaumont, C. (2013). On the origin of orogens. Geological Society of America Bulletin 125 (11-12), 1671-1702.

Ji, S., Li, A., Wang, Q., Long, C., Wang, H., Marcotte, D., \& Salisbury, M. (2013). Seismic velocities, anisotropy, and shear $\square$ wave splitting of antigorite serpentinites and tectonic implications for subduction zones. Journal of Geophysical Research: Solid Earth, 118(3), 1015-1037.

Ji, S., Shao, T., Michibayashi, K., Oya, S., Satsukawa, T., Wang, Q., ... \& Salisbury, M. H. (2015). Magnitude and symmetry of seismic anisotropy in mica $\square$ and amphibole $\square$ bearing metamorphic rocks and implications for tectonic interpretation of seismic data from the southeast Tibetan Plateau. Journal of Geophysical Research: Solid Earth, 120(9), 64046430 .

Ji, W. Q., Malusà, M. G., Tiepolo, M., Langone, A., Zhao, L., \& Wu, F. Y. (2019). Synchronous Periadriatic magmatism in the Western and Central Alps in the absence of slab breakoff. Terra Nova, 31(2), 120-128.

Jolivet, L., \& Faccenna, C. (2000). Mediterranean extension and the Africa $\square$ Eurasia collision. Tectonics, 19(6), 1095-1106.

This article is protected by copyright. All rights reserved. 
Jolivet, L., Faccenna, C., Goffé, B., Burov, E., \& Agard, P. (2003). Subduction tectonics and exhumation of high-pressure metamorphic rocks in the Mediterranean orogens. American Journal of Science, 303(5), 353-409.

Jolivet, L., Faccenna, C., \& Piromallo, C. (2009). From mantle to crust: Stretching the Mediterranean. Earth and Planetary Science Letters, 285(1-2), 198-209.

Karato, S. I. (2010). Rheology of the Earth's mantle: A historical review. Gondwana Research, $18(1), 17-45$.

Kästle, E. D., El $\square$ Sharkawy, A., Boschi, L., Meier, T., Rosenberg, C., Bellahsen, N., ... \& Weidle, C. (2018). Surface wave tomography of the alps using ambient $\square$ noise and earthquake phase velocity measurements. Journal of Geophysical Research: Solid Earth, 123(2), 1770-1792.

Kästle, E. D., Rosenberg, C., Boschi, L., Bellahsen, N., Meier, T., \& El-Sharkawy, A. (2020). Slab break-offs in the Alpine subduction zone. International Journal of Earth Sciences, 117.

Keller, L. M., Hess, M., Fügenschuh, B., \& Schmid, S. M. (2005). Structural and metamorphic evolution of the Camughera-Moncucco, Antrona and Monte Rosa units southwest of the Simplon line, Western Alps. Eclogae Geologicae Helvetiae, 98(1), 19-49.

Kennett, B. L., Engdahl, E. R., \& Buland, R. (1995). Constraints on seismic velocities in the Earth from traveltimes. Geophysical Journal International, 122(1), 108-124.

Kerckhove, C. (1969). La 'zone du Flysch' dans les nappes de l'Embrunais-Ubaye (Alpes occidentales). Géologie alpine, 45, 5-204.

Kern, H., Jin, Z., Gao, S., Popp, T., \& Xu, Z. (2002). Physical properties of ultrahigh-pressure metamorphic rocks from the Sulu terrain, eastern central China: implications for the seismic structure at the Donghai (CCSD) drilling site. Tectonophysics, 354(3-4), 315330.

Khazanehdari, J., Rutter, E. H., \& Brodie, K. H. (2000). High $\square$ pressure $\square$ high $\square$ temperature seismic velocity structure of the midcrustal and lower crustal rocks of the Ivrea $\square$ Verbano zone and Serie dei Laghi, NW Italy. Journal of Geophysical Research: Solid Earth, 105(B6), 13843-13858.

Kilian, W. and Revil, J. (1903). Contributions à la connaissance de la zone du Briançonnais, le Jurassique supérieur. De Alliers Frères (eds), 31 p.

Kissling, E. (1988). Geotomography with local earthquake data. Reviews of Geophysics, 26(4), 659-698.

Kissling, E. (1993). Deep structure of the Alps-what do we really know? Physics of the Earth and Planetary Interiors, 79(1-2), 87-112.

Kissling, E., \& Schlunegger, F. (2018). Rollback orogeny model for the evolution of the Swiss Alps. Tectonics, 37(4), 1097-1115.

Kissling, E., Schmid, S. M., Lippitsch, R., Ansorge, J., \& Fügenschuh, B. (2006). Lithosphere structure and tectonic evolution of the Alpine arc: New evidence from high-resolution teleseismic tomography. Geol. Soc. London Mem., 32, 129-145.

This article is protected by copyright. All rights reserved. 
Koulakov, I., Kaban, M. K., Tesauro, M., \& Cloetingh, S. A. P. L. (2009). P-and S-velocity anomalies in the upper mantle beneath Europe from tomographic inversion of ISC data. Geophysical Journal International, 179(1), 345-366.

Kovács, I., Csontos, L., Szabó, C., Bali, E., Falus, G., Benedek, K., \& Zajacz, Z. (2007). Paleogene-early Miocene igneous rocks and geodynamics of the Alpine-CarpathianPannonian-Dinaric region: an integrated approach. Geological Society of America Special Paper 418, 93-112.

Lagabrielle, Y., \& Cannat, M. (1990). Alpine Jurassic ophiolites resemble the modern central Atlantic basement. Geology, 18(4), 319-322.

Lagabrielle, Y., \& Lemoine, M. (1997). Alpine, Corsican and Apennine ophiolites: the slowspreading ridge model. Comptes Rendus de l'Académie des Sciences-Series IIA-Earth and Planetary Science, 325(12), 909-920.

Lanari, P., Guillot, S., Schwartz, S., Vidal, O., Tricart, P., Riel, N., \& Beyssac, O. (2012). Diachronous evolution of the alpine continental subduction wedge: evidence from P-T estimates in the Briançonnais Zone houillère (France-Western Alps). Journal of Geodynamics, 56, 39-54.

Langston, C. A. (1979). Structure under Mount Rainier, Washington, inferred from teleseismic body waves. Journal of Geophysical Research: Solid Earth, 84(B9), 4749-4762.

Lapen, T. J., Johnson, C. M., Baumgartner, L. P., Mahlen, N. J., Beard, B. L., \& Amato, J. M. (2003). Burial rates during prograde metamorphism of an ultra-high-pressure terrane: an example from Lago di Cignana, western Alps, Italy. Earth and Planetary Science Letters, 215(1-2), 57-72.

Lardeaux, J. M., Schwartz, S., Tricart, P., Paul, A., Guillot, S., Béthoux, N., \& Masson, F. (2006). A crustal $\square$ scale cross $\square$ section of the south $\square$ western Alps combining geophysical and geological imagery. Terra Nova, 18(6), 412-422.

Larose, E., Margerin, L., Derode, A., van Tiggelen, B., Campillo, M., Shapiro, N., ... \& Tanter, M. (2006). Correlation of random wavefields: An interdisciplinary review. Geophysics, 71(4), SI11-SI21.

Laubscher, H. P. (1974). Evoluzione e struttura delle Alpi. Le Scienze 72, 264-275.

Lemoine, M., Bas, T., Arnaud-Vanneau, A., Arnaud, H., Dumont, T., Gidon, M., ... \& Tricart, P. (1986). The continental margin of the Mesozoic Tethys in the Western Alps. Marine and petroleum geology, 3(3), 179-199.

Lenze, A., \& Stöckhert, B. (2007). Microfabrics of UHP metamorphic granites in the Dora Maira Massif, western Alps-no evidence of deformation at great depth. Journal of Metamorphic Geology, 25(4), 461-475.

Liao, J., Gerya, T., \& Malusà, M. G. (2018a). 3D modeling of crustal shortening influenced by along-strike lithological changes: Implications for continental collision in the Western and Central Alps. Tectonophysics, 746, 425-438.

Liao, J., Malusà, M. G., Zhao, L., Baldwin, S. L., Fitzgerald, P. G., \& Gerya, T. (2018b).

Divergent plate motion drives rapid exhumation of (ultra) high pressure rocks. Earth and Planetary Science Letters, 491, 67-80.

This article is protected by copyright. All rights reserved. 
Liati, A., \& Froitzheim, N. (2006). Assessing the Valais ocean, Western Alps: U-Pb SHRIMP zircon geochronology of eclogite in the Balma unit, on top of the Monte Rosa nappe. European Journal of Mineralogy, 18(3), 299-308.

Ligorria, J. P., \& Ammon, C. J. (1999). Iterative deconvolution and receiver-function estimation. Bulletin of the seismological Society of America, 89(5), 1395-1400.

Link, F., \& Rümpker, G. (2020). The mantle flow below the Alps from isolated mantle anisotropy based on differential Ps - XKS Splitting. Geophysical Research Abstracts 22, EGU2020-2810.

Lippitsch, R., Kissling, E., \& Ansorge, J. (2003). Upper mantle structure beneath the Alpine orogen from high $\square$ resolution teleseismic tomography. Journal of Geophysical Research: Solid Earth, 108(B8).

Lombardo, B., Nervo, R., Compagnoni, R., Messiga, B., Kienast, J.R., Mével, C., Fiora, L., Piccardo, G.B., \& Lanza, R. (1978). Osservazioni preliminari sulle ofiolite metamorfiche del Monviso (Alpi Occidentali). Rendiconti della Societa Italiana di Mineralogia e Petrologia 34, 253-305.

Long, M. D., \& Silver, P. G. (2008). The subduction zone flow field from seismic anisotropy: A global view. science, 319(5861), 315-318.

Long, M. D., \& Silver, P. G. (2009). Shear wave splitting and mantle anisotropy: Measurements, interpretations, and new directions. Surveys in Geophysics, 30(4-5), 407-461.

Lu, Y., Stehly, L., Paul, A., \& AlpArray Working Group. (2018). High-resolution surface wave tomography of the European crust and uppermost mantle from ambient seismic noise. Geophysical Journal International, 214(2), 1136-1150.

Lu, Y., Stehly, L., Brossier, R., \& Paul, A. (2020). Imaging Alpine crust using ambient noise wave-equation tomography. Geophysical Journal International, 22, 69-85.

Lucente, F. P., Margheriti, L., Piromallo, C., \& Barruol, G. (2006). Seismic anisotropy reveals the long route of the slab through the western-central Mediterranean mantle. Earth and Planetary Science Letters, 241(3-4), 517-529.

Lugeon, M. (1901). Les grandes nappes de recouvrement des Alpes du Chablais et de la Suisse. Bull. Soc. Geol. de France, 4e Ser, 50, 723-825.

Lugeon, M. (1902). Les grandes dislocations et la naissance des Alpes suisses. Impr. W. Kündig.

Lustrino, M., Duggen, S., \& Rosenberg, C. L. (2011). The Central-Western Mediterranean: anomalous igneous activity in an anomalous collisional tectonic setting. Earth-Science Reviews, 104(1-3), 1-40.

Lyon-Caen, H., \& Molnar, P. (1989). Constraints on the deep structure and dynamic processes beneath the Alps and adjacent regions from an analysis of gravity anomalies. Geophysical Journal International, 99(1), 19-32.

Lyu, C., Pedersen, H. A., Paul, A., Zhao, L., \& Solarino, S. (2017). Shear wave velocities in the upper mantle of the Western Alps: new constraints using array analysis of seismic surface waves. Geophysical Journal International, 210(1), 321-331.

This article is protected by copyright. All rights reserved. 
Macera, P., Gasperini, D., Ranalli, G., \& Mahatsente, R. (2008). Slab detachment and mantle plume upwelling in subduction zones: an example from the Italian South-Eastern Alps. Journal of Geodynamics, 45(1), 32-48.

Maffione, M., Speranza, F., Faccenna, C., Cascella, A., Vignaroli, G., \& Sagnotti, L. (2008). A synchronous Alpine and Corsica $\square$ Sardinia rotation. Journal of Geophysical Research: Solid Earth, 113(B3).

Mainprice, D., Barruol, G., \& Ismail, W. B. (2000). The seismic anisotropy of the Earth's mantle: from single crystal to polycrystal. Geophysical monograph-American Geophysical Union, 117, 237-264.

Malusà, M. G., \& Balestrieri, M. L. (2012). Burial and exhumation across the Alps-Apennines junction zone constrained by fission $\square$ track analysis on modern river sands. Terra Nova, 24(3), 221-226.

Malusà, M. G., Polino, R., \& Martin, S. (2005). The Gran San Bernardo nappe in the Aosta valley (western Alps): a composite stack of distinct continental crust units. Bulletin de la Société géologique de France, 176(5), 417-431.

Malusà, M. G., Polino, R., \& Zattin, M. (2009). Strain partitioning in the axial NW Alps since the Oligocene. Tectonics, 28(3).

Malusà, M. G., Faccenna, C., Garzanti, E., \& Polino, R. (2011). Divergence in subduction zones and exhumation of high pressure rocks (Eocene Western Alps). Earth and Planetary Science Letters, 310(1-2), 21-32.

Malusà, M. G., Faccenna, C., Baldwin, S. L., Fitzgerald, P. G., Rossetti, F., Balestrieri, M. L., ... \& Piromallo, C. (2015). Contrasting styles of (U) HP rock exhumation along the Cenozoic Adria $\square$ Europe plate boundary (Western Alps, Calabria, Corsica). Geochemistry, Geophysics, Geosystems, 16(6), 1786-1824.

Malusà, M. G., Danišík, M., \& Kuhlemann, J. (2016a). Tracking the Adriatic-slab travel beneath the Tethyan margin of Corsica-Sardinia by low-temperature thermochronometry. Gondwana Research, 31, 135-149.

Malusà, M. G., Anfinson, O. A., Dafov, L. N., \& Stockli, D. F. (2016b). Tracking Adria indentation beneath the Alps by detrital zircon U-Pb geochronology: Implications for the Oligocene-Miocene dynamics of the Adriatic microplate. Geology, 44(2), 155-158.

Malusà, M. G., Zhao, L., Eva, E., Solarino, S., Paul, A., Guillot, S., ... \& Pondrelli, S. (2017). Earthquakes in the western Alpine mantle wedge. Gondwana Research, 44, 89-95.

Malusà, M. G., Frezzotti, M. L., Ferrando, S., Brandmayr, E., Romanelli, F., \& Panza, G. F. (2018). Active carbon sequestration in the Alpine mantle wedge and implications for long-term climate trends. Scientific reports, 8(1), 1-8.

Manatschal, G. (2004). New models for evolution of magma-poor rifted margins based on a review of data and concepts from West Iberia and the Alps. International Journal of Earth Sciences, 93(3), 432-466.

Manatschal, G., \& Bernoulli, D. (1999). Architecture and tectonic evolution of nonvolcanic margins: Present $\square$ day Galicia and ancient Adria. Tectonics, 18(6), 1099-1119.

This article is protected by copyright. All rights reserved. 
Manatschal, G., \& Müntener, O. (2009). A type sequence across an ancient magma-poor oceancontinent transition: the example of the western Alpine Tethys ophiolites. Tectonophysics, 473(1-2), 4-19.

Marschall, H. R., \& Schumacher, J. C. (2012). Arc magmas sourced from mélange diapirs in subduction zones. Nature Geoscience, 5(12), 862-867.

Martini, J. (1972). Le métamorphisme dans les chaînes alpines externes et ses implications dans l'orogenèse. Schweiz. Miner. Petr. Mitt. 52, 257-276.

Masson, H., Bussy, F., Eichenberger, M., Giroud, N., Meilhac, C., \& Presniakov, S. (2008). Early Carboniferous age of the Versoyen ophiolites and consequences: non-existence of a "Valais ocean"( Lower Penninic, western Alps). Bulletin de la Société géologique de France, 179(4), 337-355.

Mechie, J., Yuan, X., Schurr, B., Schneider, F., Sippl, C., Ratschbacher, L., ... \& Moldobekov, B. (2012). Crustal and uppermost mantle velocity structure along a profile across the Pamir and southern Tien Shan as derived from project TIPAGE wide-angle seismic data. Geophysical Journal International, 188(2), 385-407.

Mercier, J. P., Bostock, M. G., Audet, P., Gaherty, J. B., Garnero, E. J., \& Revenaugh, J. (2008). The teleseismic signature of fossil subduction: Northwestern Canada. Journal of Geophysical Research: Solid Earth, 113(B4).

Michard, A., Avigad, D., Goffé, B., \& Chopin, C. (2004). The high-pressure metamorphic front of the south Western Alps (Ubaye-Maira transect, France, Italy). Schweiz. Mineral. Petrogr. Mitt, 84, 215-235.

Milnes, A. G. (1974). Structure of the Pennine Zone (Central Alps): a new working hypothesis. Geological society of America bulletin, 85(11), 1727-1732.

Mitterbauer, U., Behm, M., Brückl, E., Lippitsch, R., Guterch, A., Keller, G. R., ... \& Šmanovac, F. (2011). Shape and origin of the East-Alpine slab constrained by the ALPASS teleseismic model. Tectonophysics, 510(1-2), 195-206.

Molinari, I., \& Morelli, A. (2011). EPcrust: a reference crustal model for the European Plate. Geophysical Journal International, 185(1), 352-364.

Molinari, I., Argnani, A., Morelli, A., \& Basini, P. (2015). Development and testing of a 3D seismic velocity model of the Po Plain sedimentary basin, Italy. Bulletin of the Seismological Society of America, 105(2A), 753-764.

Molinari, I., Dasović, I., Stipčević, J., Šipka, V., Jarić, D., Kissling, E., ... \& Wiemer, S. (2018). Investigation of the central Adriatic lithosphere structure with the AlpArray-CASE seismic experiment. Geofizika, 35(2), 103-128.

Mohn, G., Manatschal, G., Müntener, O., Beltrando, M., \& Masini, E. (2010). Unravelling the interaction between tectonic and sedimentary processes during lithospheric thinning in the Alpine Tethys margins. International Journal of Earth Sciences, 99(1), 75-101.

Nicolas, A., Bouchez, J. L., \& Boudier, F. (1972). Interprétation cinématique des déformations plastiques dans le massif de lherzolite de Lanzo (Alpes piemontaises)—comparaison avec d'autres massifs. Tectonophysics, 14(2), 143-171.

This article is protected by copyright. All rights reserved. 
Nicolas, A., Hirn, A., Nicolich, R., \& Polino, R. (1990a). Lithospheric wedging in the western Alps inferred from the ECORS-CROP traverse. Geology, 18(7), 587-590.

Nicolas, A., Polino, R., Hirn, A., \& Nicolich, R. (1990b). ECORS-CROP traverse and deep structure of the western Alps: a synthesis. Mémoires de la Société géologique de France (1833), 156, 15-27.

Nocquet, J. M., Sue, C., Walpersdorf, A., Tran, T., Lenôtre, N., Vernant, P., ... \& Chery, J. (2016). Present-day uplift of the western Alps. Scientific reports, 6(1), 1-6.

O’Brien, P. J. (2001). Subduction followed by collision: Alpine and Himalayan examples. Physics of the Earth and Planetary Interiors, 127(1-4), 277-291.

Oxburgh, E. R. (1972). Flake tectonics and continental collision. Nature, 239(5369), 202-204.

Paffrath, M., Friederich, W., \& the AlpArray Working Group (2020). Teleseismic P-wave travel time tomography of the Alpine upper mantle using AlpArray seismic network data. Geophysical Research Abstracts 22, EGU2020-13779.

Paquette, J. L., Montel, J. M., \& Chopin, C. (1999). U-Th-Pb dating of the Brossasco ultrahighpressure metagranite, Dora-Maira massif, western Alps. European Journal of Mineralogy, 11(1), 69-77.

Paul, A., Cattaneo, M., Thouvenot, F., Spallarossa, D., Béthoux, N., \& Fréchet, J. (2001). A three $\square$ dimensional crustal velocity model of the southwestern Alps from local earthquake tomography. Journal of Geophysical Research: Solid Earth, 106(B9), 1936719389.

Pawley, A. R. (1994). The pressure and temperature stability limits of lawsonite: implications for $\mathrm{H} 2 \mathrm{O}$ recycling in subduction zones. Contributions to Mineralogy and Petrology, 118(1), 99-108.

Peacock, S. M., \& Hyndman, R. D. (1999). Hydrous minerals in the mantle wedge and the maximum depth of subduction thrust earthquakes. Geophysical Research Letters, 26(16), 2517-2520.

Peccerillo, A., \& Frezzotti, M. L. (2015). Magmatism, mantle evolution and geodynamics at the converging plate margins of Italy. Journal of the Geological Society, 172(4), 407-427.

Pera, E., Mainprice, D., \& Burlini, L. (2003). Anisotropic seismic properties of the upper mantle beneath the Torre Alfina area (Northern Apennines, Central Italy). Tectonophysics, $370(1-4), 11-30$.

Pfiffner, O. A., Schlunegger, F., \& Buiter, S. J. H. (2002). The Swiss Alps and their peripheral foreland basin: Stratigraphic response to deep crustal processes. Tectonics, 21(2), 3-1.

Pfiffner, O. A. (2014). Geology of the Alps. John Wiley \& Sons.

Piana Agostinetti, N., Salimbeni, S., Pondrelli, S., Malusà, M. G., Zhao, L., Eva, E., Solarino, S., Paul, A., Guillot, S., Schwartz, S., Dumont, T., Aubert, C., Wang, Q., \& Zhu, R. (2017). Mantle wedge anisotropy beneath the Western Alps: insights from Receiver Function analysis. Geophysical Research Abstracts 19, EGU2017-12545.

Piccardo, G. B. (2003). Mantle processes during ocean formation: petrologic records in peridotites from the Alpine-Apennine ophiolites. Episodes, 26(3), 193-199.

This article is protected by copyright. All rights reserved. 
Piccardo, G. B., \& Vissers, R. L. M. (2007). The pre-oceanic evolution of the Erro-Tobbio peridotite (Voltri Massif, Ligurian Alps, Italy). Journal of Geodynamics, 43(4-5), 417449.

Piccardo, G. B., Zanetti, A., \& Müntener, O. (2007). Melt/peridotite interaction in the Southern Lanzo peridotite: field, textural and geochemical evidence. Lithos, 94(1-4), 181-209.

Piromallo, C., \& Faccenna, C. (2004). How deep can we find the traces of Alpine subduction?. Geophysical Research Letters, 31(6).

Piromallo, C., \& Morelli, A. (2003). P wave tomography of the mantle under the Alpine $\square$ Mediterranean area. Journal of Geophysical Research: Solid Earth, 108(B2).

Piromallo, C., Becker, T. W., Funiciello, F., \& Faccenna, C. (2006). Three $\square$ dimensional instantaneous mantle flow induced by subduction. Geophysical Research Letters, 33(8).

Plomerová, J., Žlebčíková, H., Hetényi, G., Vecsey, L., Babuška, V., the AlpArray-EASI Working Group, and the AlpArray Working Group (2020). Tomography image of double high-velocity heterogeneity beneath the Eastern Alps from the AlpArray data. Geophysical Research Abstracts 22, EGU2020-7728.

Poli, S. (2015). Carbon mobilized at shallow depths in subduction zones by carbonatitic liquids. Nature Geoscience, 8(8), 633-636.

Poli, S., \& Schmidt, M. W. (2002). Petrology of subducted slabs. Annual Review of Earth and Planetary Sciences, 30(1), 207-235.

Polino, R., \& Lemoine, M. (1984). Détritisme mixte d'origine continentale et océanique dans les sédiments jurassico-crétacés supra-ophiolitiques de la Téthys ligure: la série du Lago Nero (Alpes Occidentales franco-italiennes). Comptes-rendus des séances de l'Académie des sciences. Série 2, Mécanique-physique, chimie, sciences de l'univers, sciences de la terre, 298(8), 359-364.

Polino, R., et al. (Coord.) (2012), Carta Geologica d'Italia alla Scala 1:50.000—Foglio 090 Aosta, Regione Autonoma Valle d'Aosta-ISPRA, Roma.

Qorbani, E., Bianchi, I., \& Bokelmann, G. (2015). Slab detachment under the Eastern Alps seen by seismic anisotropy. Earth and planetary science letters, 409, 96-108.

Quick, J. E., Sinigoi, S., \& Mayer, A. (1994). Emplacement dynamics of a large mafic intrusion in the lower crust, Ivrea $\square$ Verbano Zone, northern Italy. Journal of Geophysical Research: Solid Earth, 99(B11), 21559-21573.

Ramsay, J. G. (1963). Stratigraphy, structure and metamorphism in the Western Alps. Proceedings of the Geologists' Association, 74(3), 357-IN12.

Reinecke, T. (1991). Very-high-pressure metamorphism and uplift of coesite-bearing metasediments from the Zermatt-Saas zone, Western Alps. European Journal of Mineralogy, 7-18.

Reynard, B. (2013). Serpentine in active subduction zones. Lithos, 178, 171-185.

Rosenberg, C. L., Schneider, S., Scharf, A., Bertrand, A., Hammerschmidt, K., Rabaute, A., \& Brun, J. P. (2018). Relating collisional kinematics to exhumation processes in the Eastern Alps. Earth-Science Reviews, 176, 311-344.

This article is protected by copyright. All rights reserved. 
Rossi, M., Mosca, P., Polino, R., Rogledi, S., \& Biffi, U. (2009). New outcrop and subsurface data in the Tertiary Piedmont Basin (NW-Italy): unconformity-bounded stratigraphic units and their relationships with basin-modification phases. Rivista Italiana di Paleontologia e Stratigrafia, 115(3), 305-335.

Rouméjon, S., \& Cannat, M. (2014). Serpentinization of mantle $\square$ derived peridotites at mid $\square$ ocean ridges: Mesh texture development in the context of tectonic exhumation. Geochemistry, Geophysics, Geosystems, 15(6), 2354-2379.

Roure, F., Bergerat, F., Damotte, B., Mugnier, J. L., \& Polino, R. (1996). The ECORS-CROP Alpine seismic traverse. Mémoires de la Société géologique de France (1833), 170.

Rubatto, D., \& Hermann, J. (2001). Exhumation as fast as subduction?. Geology, 29(1), 3-6.

Rubatto, D., Gebauer, D., \& Fanning, M. (1998). Jurassic formation and Eocene subduction of the Zermatt-Saas-Fee ophiolites: implications for the geodynamic evolution of the Central and Western Alps. Contributions to Mineralogy and Petrology, 132(3), 269-287.

Rubatto, D., Müntener, O., Barnhoorn, A., \& Gregory, C. (2008). Dissolution-reprecipitation of zircon at low-temperature, high-pressure conditions (Lanzo Massif, Italy). American Mineralogist, 93(10), 1519-1529.

Rudnick, R. L., \& Fountain, D. M. (1995). Nature and composition of the continental crust: a lower crustal perspective. Reviews of geophysics, 33(3), 267-309.

Salimbeni, S., Pondrelli, S., Margheriti, L., Park, J., \& Levin, V. (2008). SKS splitting measurements beneath Northern Apennines region: a case of oblique trench-retreat. Tectonophysics, 462(1-4), 68-82.

Salimbeni, S., Pondrelli, S., \& Margheriti, L. (2013). Hints on the deformation penetration induced by subductions and collision processes: Seismic anisotropy beneath the Adria region (Central Mediterranean). Journal of Geophysical Research: Solid Earth, 118(11), 5814-5826.

Salimbeni, S., Malusà, M. G., Zhao, L., Guillot, S., Pondrelli, S., Margheriti, L., Paul, A., Solarino, S., Aubert, C., Dumont, T., Schwartz, S., Wang, Q., Xu, X., Zheng, T., \& Zhu, R. (2018). Active and fossil mantle flows in the western Alpine region unravelled by seismic anisotropy analysis and high-resolution $\mathrm{P}$ wave tomography. Tectonophysics, 731, 35-47.

Savage, M. K. (1999). Seismic anisotropy and mantle deformation: what have we learned from shear wave splitting?. Reviews of Geophysics, 37(1), 65-106.

Savage, M. K., \& Sheehan, A. F. (2000). Seismic anisotropy and mantle flow from the Great Basin to the Great Plains, western United States. Journal of Geophysical Research: Solid Earth, 105(B6), 13715-13734.

Scafidi, D., Solarino, S., \& Eva, C. (2006). Structure and properties of the Ivrea body and of the Alps-Apennines system as revealed by local earthquake tomography. Boll. Geofis. Teor.

Scafidi, D., Solarino, S., \& Eva, C. (2009). P wave seismic velocity and Vp/Vs ratio beneath the Italian peninsula from local earthquake tomography. Tectonophysics, 465(1-4), 1-23.

This article is protected by copyright. All rights reserved. 
Scambelluri, M., Müntener, O., Hermann, J., Piccardo, G. B., \& Trommsdorff, V. (1995). Subduction of water into the mantle: history of an Alpine peridotite. Geology, 23(5), 459462.

Schaltegger, U., \& Brack, P. (2007). Crustal-scale magmatic systems during intracontinental strike-slip tectonics: $\mathrm{U}, \mathrm{Pb}$ and $\mathrm{Hf}$ isotopic constraints from Permian magmatic rocks of the Southern Alps. International Journal of Earth Sciences, 96(6), 1131-1151.

Schlunegger, F., \& Castelltort, S. (2016). Immediate and delayed signal of slab breakoff in Oligo/Miocene Molasse deposits from the European Alps. Scientific reports, 6, 31010.

Schlunegger, F., \& Kissling, E. (2015). Slab rollback orogeny in the Alps and evolution of the Swiss Molasse basin. Nature communications, 6(1), 1-10.

Schmid, S. M., \& Kissling, E. (2000). The arc of the western Alps in the light of geophysical data on deep crustal structure. Tectonics, 19(1), 62-85.

Schmid, S. M., Pfiffner, O. A., Froitzheim, N., Schönborn, G., \& Kissling, E. (1996). Geophysical $\square$ geological transect and tectonic evolution of the Swiss $\square$ Italian Alps. Tectonics, 15(5), 1036-1064.

Schmid, S. M., Fügenschuh, B., Kissling, E., \& Schuster, R. (2004). Tectonic map and overall architecture of the Alpine orogen. Eclogae Geologicae Helvetiae, 97(1), 93-117.

Schmid, S. M., Scharf, A., Handy, M. R., \& Rosenberg, C. L. (2013). The Tauern Window (Eastern Alps, Austria): a new tectonic map, with cross-sections and a tectonometamorphic synthesis. Swiss Journal of Geosciences, 106(1), 1-32.

Schmid, S. M., Kissling, E., Diehl, T., van Hinsbergen, D. J., \& Molli, G. (2017). Ivrea mantle wedge, arc of the Western Alps, and kinematic evolution of the Alps-Apennines orogenic system. Swiss Journal of Geosciences, 110(2), 581-612.

Schmidt, M. W., \& Poli, S. (1998). Experimentally based water budgets for dehydrating slabs and consequences for arc magma generation. Earth and Planetary Science Letters, 163(14), 361-379.

Schmidt, M. W., Vielzeuf, D., \& Auzanneau, E. (2004). Melting and dissolution of subducting crust at high pressures: the key role of white mica. Earth and Planetary Science Letters, 228(1-2), 65-84.

Schwartz, S., Lardeaux, J. M., Guillot, S., \& Tricart, P. (2000). Diversité du métamorphisme éclogitique dans le massif ophiolitique du Monviso (Alpes occidentales, Italie). Geodinamica Acta, 13(2-3), 169-188.

Schwartz, S., Allemand, P., \& Guillot, S. (2001). Numerical model of the effect of serpentinites on the exhumation of eclogitic rocks: insights from the Monviso ophiolitic massif (Western Alps). Tectonophysics, 342(1-2), 193-206.

Schwartz, S., Tricart, P., Lardeaux, J. M., Guillot, S., \& Vidal, O. (2009). Late tectonic and metamorphic evolution of the Piedmont accretionary wedge (Queyras Schistes lustrés, western Alps): Evidences for tilting during Alpine collision. Geological Society of America Bulletin, 121(3-4), 502-518.

This article is protected by copyright. All rights reserved. 
Schwartz, S., Guillot, S., Reynard, B., Lafay, R., Debret, B., Nicollet, C., ... \& Auzende, A. L. (2013). Pressure-temperature estimates of the lizardite/antigorite transition in high pressure serpentinites. Lithos, 178, 197-210.

Serpelloni, E., Faccenna, C., Spada, G., Dong, D., \& Williams, S. D. (2013). Vertical GPS ground motion rates in the Euro $\square$ Mediterranean region: New evidence of velocity gradients at different spatial scales along the Nubia $\square$ Eurasia plate boundary. Journal of Geophysical Research: Solid Earth, 118(11), 6003-6024.

Shapiro, N. M., Campillo, M., Stehly, L., \& Ritzwoller, M. H. (2005). High-resolution surfacewave tomography from ambient seismic noise. Science, 307(5715), 1615-1618.

Shinohara, M., Fukano, T., Kanazawa, T., Araki, E., Suyehiro, K., Mochizuki, M., ... \& Mochizuki, K. (2008). Upper mantle and crustal seismic structure beneath the Northwestern Pacific Basin using a seafloor borehole broadband seismometer and ocean bottom seismometers. Physics of the Earth and Planetary Interiors, 170(1-2), 95-106.

Silver, P.G., Mainprice, D., Ismail, W.B., Tommasi, A., \& Barruol, G. (1999). Mantle structural geology from seismic anisotropy. Spec. Publ. Geochem. Soc. 6, 79-103.

Simmons, N. A., Forte, A. M., Boschi, L., \& Grand, S. P. (2010). GyPSuM: A joint tomographic model of mantle density and seismic wave speeds. Journal of Geophysical Research: Solid Earth, 115(B12).

Sinclair, H. D. (1997). Flysch to molasse transition in peripheral foreland basins: The role of the passive margin versus slab breakoff. Geology, 25(12), 1123-1126.

Solarino, S., Kissling, E., Sellami, S., Smriglio, G., Thouvenot, F., Granet, M., ... \& Slejko, D. (1997). Compilation of a recent seismicity data base of the greater Alpine region from several seismological networks and preliminary 3D tomographic results.

Solarino, S., Malusà, M.G., Eva, E., Guillot, S., Paul, A., Schwartz, S., Zhao, L., Aubert, C., Dumont, T., Pondrelli, S., Salimbeni, S., Wang, Q., Xu, X., Zheng, T., \& Zhu, R. (2018). Mantle wedge exhumation beneath the Dora-Maira (U) HP dome unravelled by local earthquake tomography (Western Alps). Lithos, 296, 623-636.

Spada, M., Bianchi, I., Kissling, E., Agostinetti, N. P., \& Wiemer, S. (2013). Combining controlled-source seismology and receiver function information to derive 3-D Moho topography for Italy. Geophysical Journal International, 194(2), 1050-1068.

Spakman, W., \& Wortel. R. (2004). A tomographic view on western Mediterranean geodynamics. In The TRANSMED Atlas: The Mediterranean Region From Crust to Mantle, pp. 31-52, Springer, Berlin.

Stampfli, G. M., Mosar, J., Marquer, D., Marchant, R., Baudin, T., \& Borel, G. (1998). Subduction and obduction processes in the Swiss Alps. Tectonophysics, 296(1-2), 159204.

Stampfli, G. M., Borel, G. D., Marchant, R., \& Mosar, J. (2002). Western Alps geological constraints on western Tethyan reconstructions. Journal of the Virtual Explorer, 8, 77.

Sternai, P., Sue, C., Husson, L., Serpelloni, E., Becker, T. W., Willett, S. D., ... \& Valla, P. (2019). Present-day uplift of the European Alps: Evaluating mechanisms and models of their relative contributions. Earth-science reviews, 190, 589-604.

This article is protected by copyright. All rights reserved. 
Sue, C., Thouvenot, F., Fréchet, J., \& Tricart, P. (1999). Widespread extension in the core of the western Alps revealed by earthquake analysis. Journal of Geophysical Research: Solid Earth, 104(B11), 25611-25622.

Sue, C., Delacou, B., Champagnac, J. D., Allanic, C., Tricart, P., \& Burkhard, M. (2007). Extensional neotectonics around the bend of the Western/Central Alps: an overview. International Journal of Earth Sciences, 96(6), 1101-1129.

Sun, W., \& Kennett, B. L. N. (2016a). Uppermost mantle structure of the Australian continent from Pn traveltime tomography. Journal of Geophysical Research: Solid Earth, 121(3), 2004-2019.

Sun, W., \& Kennett, B. L. N. (2016b). Uppermost mantle P wavespeed structure beneath eastern China and its surroundings. Tectonophysics, 683, 12-26.

Sun, W., Zhao, L., Malusà, M. G., Guillot, S., \& Fu, L. Y. (2019). 3-D Pn tomography reveals continental subduction at the boundaries of the Adriatic microplate in the absence of a precursor oceanic slab. Earth and Planetary Science Letters, 510, 131-141.

Syracuse, E. M., van Keken, P. E., \& Abers, G. A. (2010). The global range of subduction zone thermal models. Physics of the Earth and Planetary Interiors, 183(1-2), 73-90.

Tardy, M., Bethoux, N., Lardeaux, J. M., \& Paul, A. (1999). The Géofrance 3D project in the western Alps: a synthesis. Documents du BRGM. Géologie régionale et générale, (293), 52-63.

Thöni, M. (2006). Dating eclogite-facies metamorphism in the Eastern Alps-approaches, results, interpretations: a review. Mineralogy and Petrology, 88(1-2), 123-148.

Thouvenot, F., Paul, A., Senechal, G., Hirn, A., \& Nicolich, R. (1990). ECORS-CROP wideangle reflection seismics: constraints on deep interfaces beneath the Alps. In Deep structure of the Alps (Vol. 156, pp. 97-106).

Thouvenot, F., Senechal, G., Truffert, C., \& Guellec, S. (1996). Comparison between two techniques of line-drawing migration (ray-tracing and common tangent method). Mem. Soc. Geol. Fr., 53-60.

Thouvenot, F., Paul, A., Frechet, J., Béthoux, N., Jenatton, L., \& Guiguet, R. (2007). Are there really superposed Mohos in the southwestern Alps? New seismic data from fan-profiling reflections. Geophysical Journal International, 170(3), 1180-1194.

Tommasi, A., Tikoff, B., \& Vauchez, A. (1999). Upper mantle tectonics: three-dimensional deformation, olivine crystallographic fabrics and seismic properties. Earth and Planetary Science Letters, 168(1-2), 173-186.

Tricart, P. (1984). From passive margin to continental collision; a tectonic scenario for the Western Alps. American Journal of Science, 284(2), 97-120.

Trümpy, R. (1960). Paleotectonic evolution of the Central and Western Alps. Geological Society of America Bulletin, 71(6), 843-907.

Ulmer, P., \& Trommsdorff, V. (1999). Phase relations of hydrous mantle subducting to $300 \mathrm{~km}$. Geochem. Soc. Spec. Pub. 6, 259-281.

This article is protected by copyright. All rights reserved. 
Ustaszewski, K., Schmid, S. M., Fügenschuh, B., Tischler, M., Kissling, E., \& Spakman, W. (2008). A map-view restoration of the Alpine-Carpathian-Dinaridic system for the Early Miocene. Swiss Journal of Geosciences, 101(1), 273-294.

Vauchez, A., Tommasi, A., \& Mainprice, D. (2012). Faults (shear zones) in the Earth's mantle. Tectonophysics, 558, 1-27.

Vignaroli, G., Faccenna, C., Jolivet, L., Piromallo, C., \& Rossetti, F. (2008). Subduction polarity reversal at the junction between the Western Alps and the Northern Apennines, Italy. Tectonophysics, 450(1-4), 34-50.

Vissers, R. L. M., Drury, M. R., Hoogerduijn, E. H., Spiers, C. J., \& Van der Wal, D. (1995). Mantle shear zones and their effect on lithosphere strength during continental breakup. Tectonophysics, 249(3-4), 155-171.

von Blanckenburg, F., \& Davies, J. H. (1995). Slab breakoff: a model for syncollisional magmatism and tectonics in the Alps. Tectonics, 14(1), 120-131.

Wagner, M., Kissling, E., \& Husen, S. (2012). Combining controlled-source seismology and local earthquake tomography to derive a 3-D crustal model of the western Alpine region. Geophysical Journal International, 191(2), 789-802.

Waldhauser, F., Lippitsch, R., Kissling, E., \& Ansorge, J. (2002). High-resolution teleseismic tomography of upper-mantle structure using an a priori three-dimensional crustal model. Geophysical Journal International, 150(2), 403-414.

Walpersdorf, A., Sue, C., Baize, S., Cotte, N., Bascou, P., Beauval, C., ... \& Hautecoeur, O. (2015). Coherence between geodetic and seismic deformation in a context of slow tectonic activity (SW Alps, France). Journal of Geodynamics, 85, 58-65.

Wang, Q., Ji, S., Salisbury, M. H., Xia, B., Pan, M., \& Xu, Z. (2005). Pressure dependence and anisotropy of P-wave velocities in ultrahigh-pressure metamorphic rocks from the DabieSulu orogenic belt (China): implications for seismic properties of subducted slabs and origin of mantle reflections. Tectonophysics, 398(1-2), 67-99.

Watanabe, T., Shirasugi, Y., Yano, H., \& Michibayashi, K. (2011). Seismic velocity in antigorite-bearing serpentinite mylonites. Geological Society, London, Special Publications, 360(1), 97-112.

Weiss, T., Siegesmund, S., Rabbel, W., Bohlen, T., \& Pohl, M. (1999). Seismic velocities and anisotropy of the lower continental crust: a review. In Seismic Exploration of the Deep Continental Crust (pp. 97-122). Birkhäuser, Basel.

Winterer, E. L., \& Bosellini, A. (1981). Subsidence and sedimentation on Jurassic passive continental margin, Southern Alps, Italy. AAPG bulletin, 65(3), 394-421.

Wortel, M. J. R., \& Spakman, W. (1992). Structure and dynamics of subducted lithosphere in the Mediterranean region. Proceedings of the Koninklijke Nederlandse Akademie van Wetenschappen, 95(3), 325-347.

Wortel, M. J. R., \& Spakman, W. (2000). Subduction and slab detachment in the MediterraneanCarpathian region. Science, 290(5498), 1910-1917.

This article is protected by copyright. All rights reserved. 
Yoshino, T., Nishihara, Y., \& Karato, S. I. (2007). Complete wetting of olivine grain boundaries by a hydrous melt near the mantle transition zone. Earth and Planetary Science Letters, 256(3-4), 466-472.

Yuan, H., \& Bodin, T. (2018). A probabilistic shear wave velocity model of the crust in the central West Australian craton constrained by transdimensional inversion of ambient noise dispersion. Tectonics, 37(7), 1994-2012.

Zanchetta, S., Garzanti, E., Doglioni, C., \& Zanchi, A. (2012). The Alps in the Cretaceous: a doubly vergent pre $\square$ collisional orogen. Terra Nova, 24(5), 351-356.

Zanchetta, S., Malusà, M. G., \& Zanchi, A. (2015). Precollisional development and Cenozoic evolution of the Southalpine retrobelt (European Alps). Lithosphere, 7(6), 662-681.

Zhao, L., Paul, A., Guillot, S., Solarino, S., Malusà, M. G., Zheng, T., ... \& Zhu, R. (2015). First seismic evidence for continental subduction beneath the Western Alps. Geology, 43(9), 815-818

Zhao, L., Paul, A. \& Solarino, S. (2016a). RESIF 2016 Seismic network YP: CIFALPS temporary experiment (China-Italy-France Alps seismic transect), RESIF - Réseau Sismologique et géodésique Français, doi:10.15778/RESIF.YP2012.

Zhao, L., Paul, A., Malusà, M.G., Xu, X., Zheng, T., Solarino, S., Guillot, S., Schwartz, S., Dumont, T., Salimbeni, S., Aubert, C., Pondrelli, S., Wang, Q., \& Zhu, R. (2016b). Continuity of the Alpine slab unraveled by high-resolution P wave tomography. Journal of Geophysical Research, 121. 8720-8737.

Zhao, L., Malusà, M.G., Yuan, H., Paul, A., Guillot, S., Lu, Y., Stehly, L., Solarino, S., Eva, E., Lu, G., Bodin, T., CIFALPS Group, \& AlpArray Working Group (2020). Evidence for a serpentinized plate interface favouring continental subduction. Nature Communications, 11, 2171, doi: 10.1038/s41467-020-15904-7

Zhu, L. (2000). Crustal structure across the San Andreas Fault, southern California from teleseismic converted waves. Earth and Planetary Science Letters, 179(1), 183-190.

Zhu, H., \& Tromp, J. (2013). Mapping tectonic deformation in the crust and upper mantle beneath Europe and the North Atlantic Ocean. Science, 341(6148), 871-875.

This article is protected by copyright. All rights reserved. 
FIGURE 1

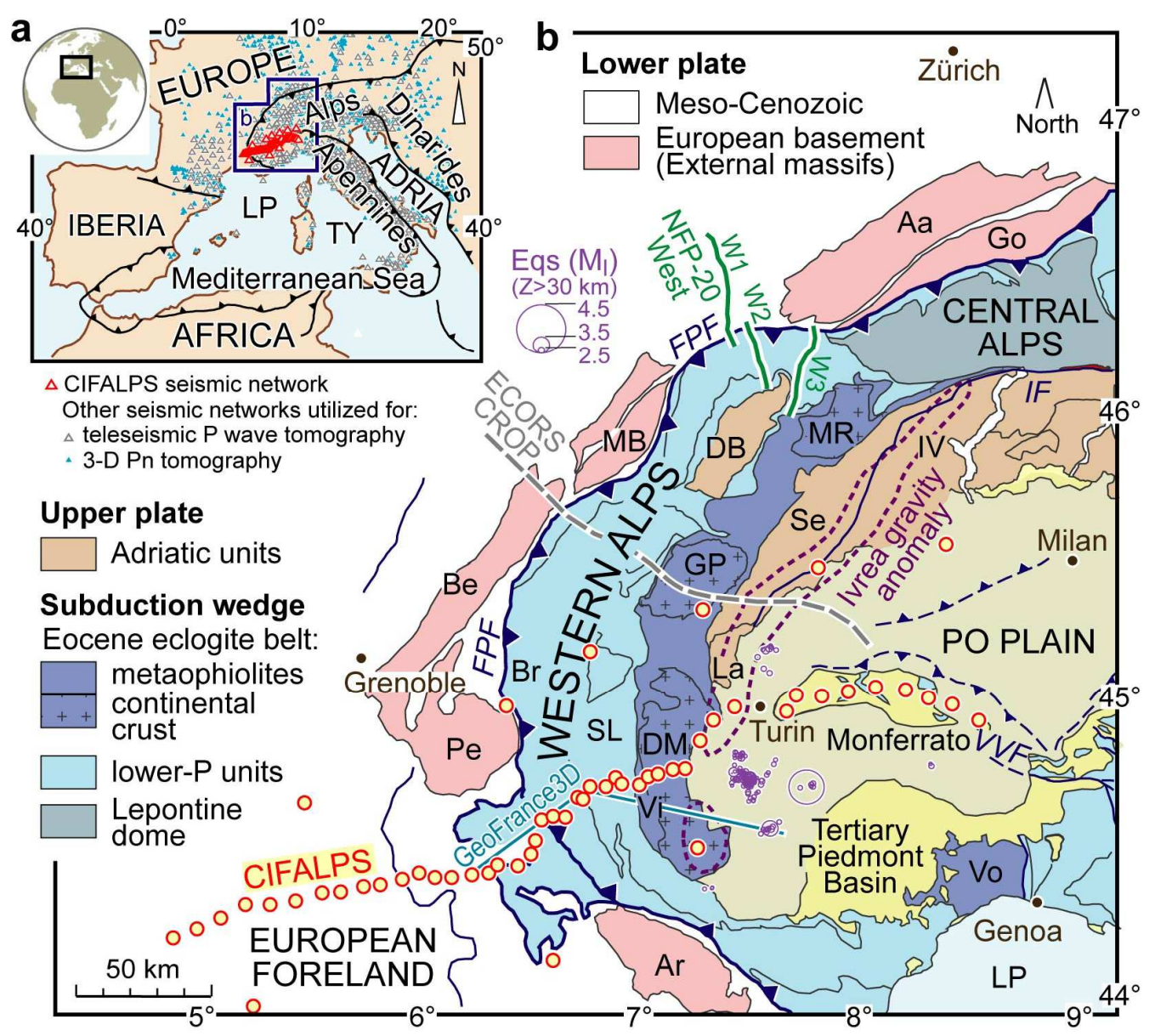

Figure 1. Tectonic setting of the study area. a: Tectonic sketch map of the Adria-Europe plate boundary zone, and distribution of seismic stations of the CIFALPS experiment and other networks used for the teleseismic P-wave and 3D Pn tomographies of Zhao et al. (2016b) and Sun et al. (2019); b: Geologic map of the Western Alps (modified after Bigi et al. 1990; Malusà et al. 2015), with location of previous geophysical transects indicated (ECORS CROP, NFP-20 West, GeoFrance 3D) and CIFALPS temporary stations. The Ivrea gravity anomaly ( $0 \mathrm{mGal}$ isoline, in purple, after Bigi et al. 1990) and the locations of anomalously deep earthquakes beneath the Po Plain (Eva et al. 2015; Malusà et al. 2017) are also indicated. Acronyms: Aa, Aar; Ar, Argentera; Be, Belledonne; Br, Briançonnais; DB, Dent Blanche; DM, Dora-Maira; FPF, Frontal Pennine Fault; Go, Gotthard; GP, Gran Paradiso; IF, Insubric Fault; IV, Ivrea-Verbano; La, Lanzo; LP, Ligurian-Provençal; MB, Mont Blanc; MR, Monte Rosa; Pe, Pelvoux; Se, Sesia-Lanzo; SL, Schistes lustrés; TY, Tyrrhenian; Vi, Viso; Vo, Voltri; VVF, Villalvernia-Varzi Fault.

This article is protected by copyright. All rights reserved. 
FIGURE 2

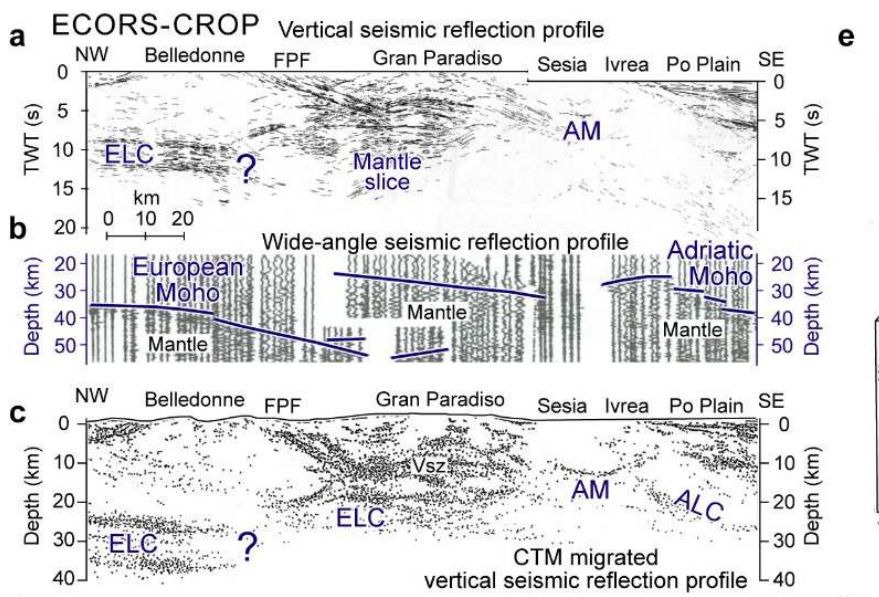

e
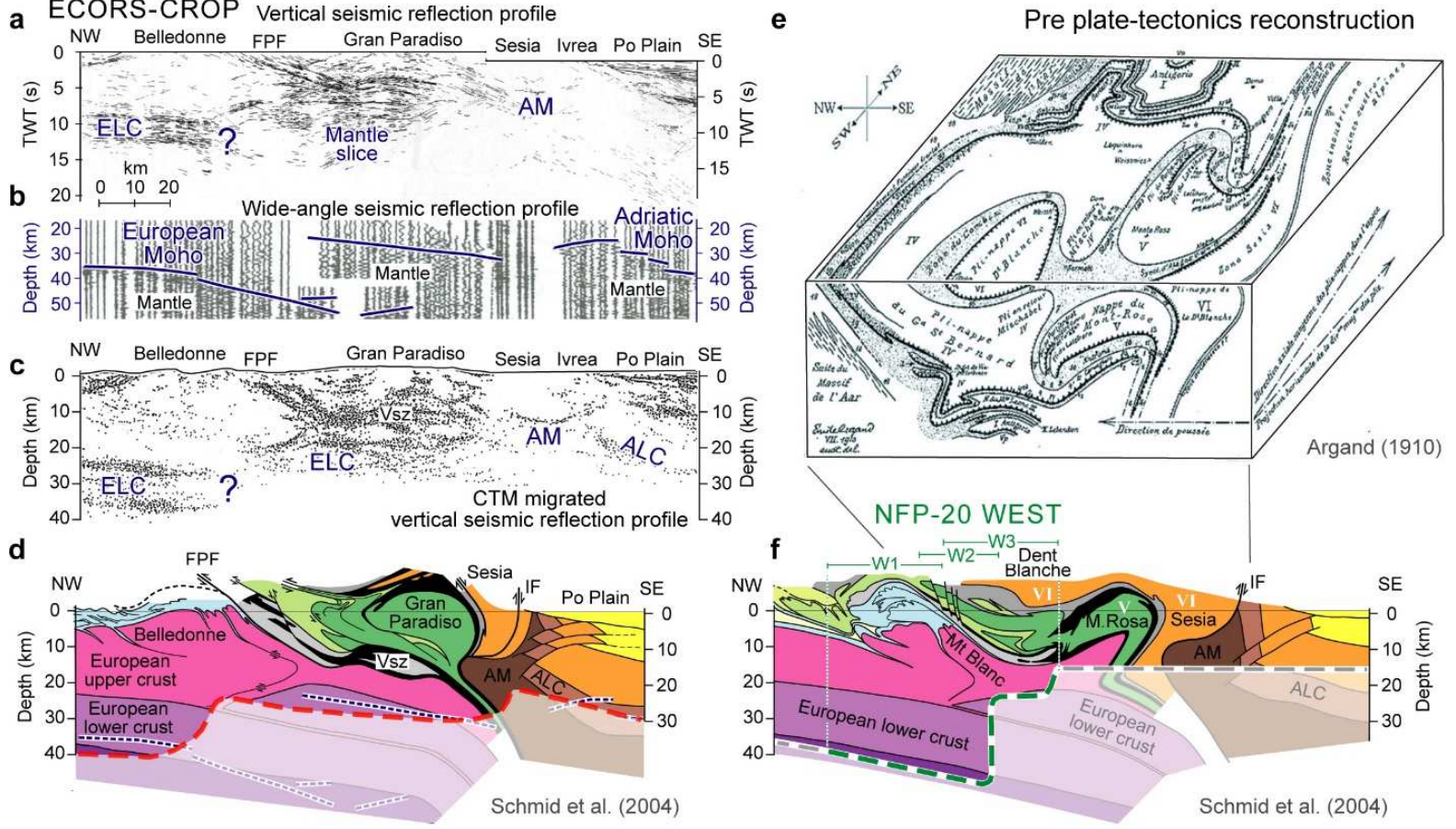

g
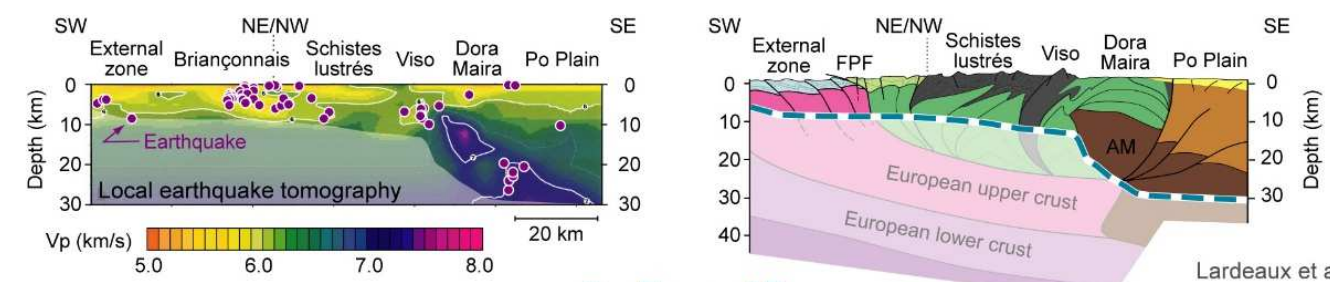

GeoFrance 3D

Lardeaux et al. (2006)

Figure 2. Crustal structure of the northern Western Alps as imaged prior to the CIFALPS passive seismic experiment. a: Line drawing of the ECORS-CROP vertical seismic reflection profile (after Nicolas et al. 1990; see location in Fig. 1b) (TWT = two-way travel time). The European lower crust (ELC) beneath the European foreland, and the top of the Adriatic mantle (AM) beneath the Ivrea zone are clearly imaged, as well as the SE-dipping Frontal Pennine Fault (FPF) and the Po Plain basin fill. To the east of the FPF, no European Moho is imaged beneath the Alpine subduction wedge. b: ECORS-CROP wide-angle reflection seismic profile (same location as profile in "a") and inferred Moho-like reflectors (thick blue lines, after Thouvenot et al. 1990). Note the reflector with Moho characteristics imaged beneath the Gran Paradiso at $25-35 \mathrm{~km}$ depth, and the European Moho imaged farther west beneath the frontal part of the Alpine metamorphic wedge. c: Migrated ECORS-CROP seismic reflection profile based on the common tangent method (CTM, after Thouvenot et al. 1996) as reinterpreted by Schmid and Kissling (2000): the reflectors at $25-35 \mathrm{~km}$ depth beneath the Gran Paradiso dome would not mark the top of a mantle slice, as proposed by Nicolas et al. (1990), but the interface between upper and lower European crust; the reflectors located at 10-15 km depth beneath the Gran Paradiso would mark the Valais suture zone (Vsz). ALC = top of the Adriatic lower crust beneath the Po Plain. d: Geologic cross-section along the ECORS-CROP traverse as proposed by Schmid et al. (2004), compared with the main

This article is protected by copyright. All rights reserved. 
interfaces detected by the wide-angle seismic experiment (dashed blue lines). Below the dashed red line, where the cross-section proposed by Schmid et al. (2004) is masked, no constraint is provided by vertical reflection seismics. e: Nappe structure in the northern Western Alps according to the pre-plate-tectonics reconstruction of Argand (1911), showing six major and laterally continuous recumbent folds-nappes (Roman numbers) with crystalline rocks enveloped by Mesozoic metasediments. f: Geologic cross-section including the area investigated by the composite NFP-20 West traverse (Frei et al. 1990, see location in Fig. 1b) as proposed by Schmid et al. (2004). Roman numbers (in white) indicate the fold-nappes of Argand (1911). Note the similarities between pre-plate-tectonics (e) and recent (f) tectonic interpretations proposed before the CIFALPS experiment. g: P-wave velocity structure (Paul et al. 2001) and geologic crosssection (Lardeaux et al. 2006) along the GeoFrance 3D profile. No constraint was provided by local earthquake tomography below the dashed blue line. See locations in Fig. 1.

This article is protected by copyright. All rights reserved. 
FIGURE 3

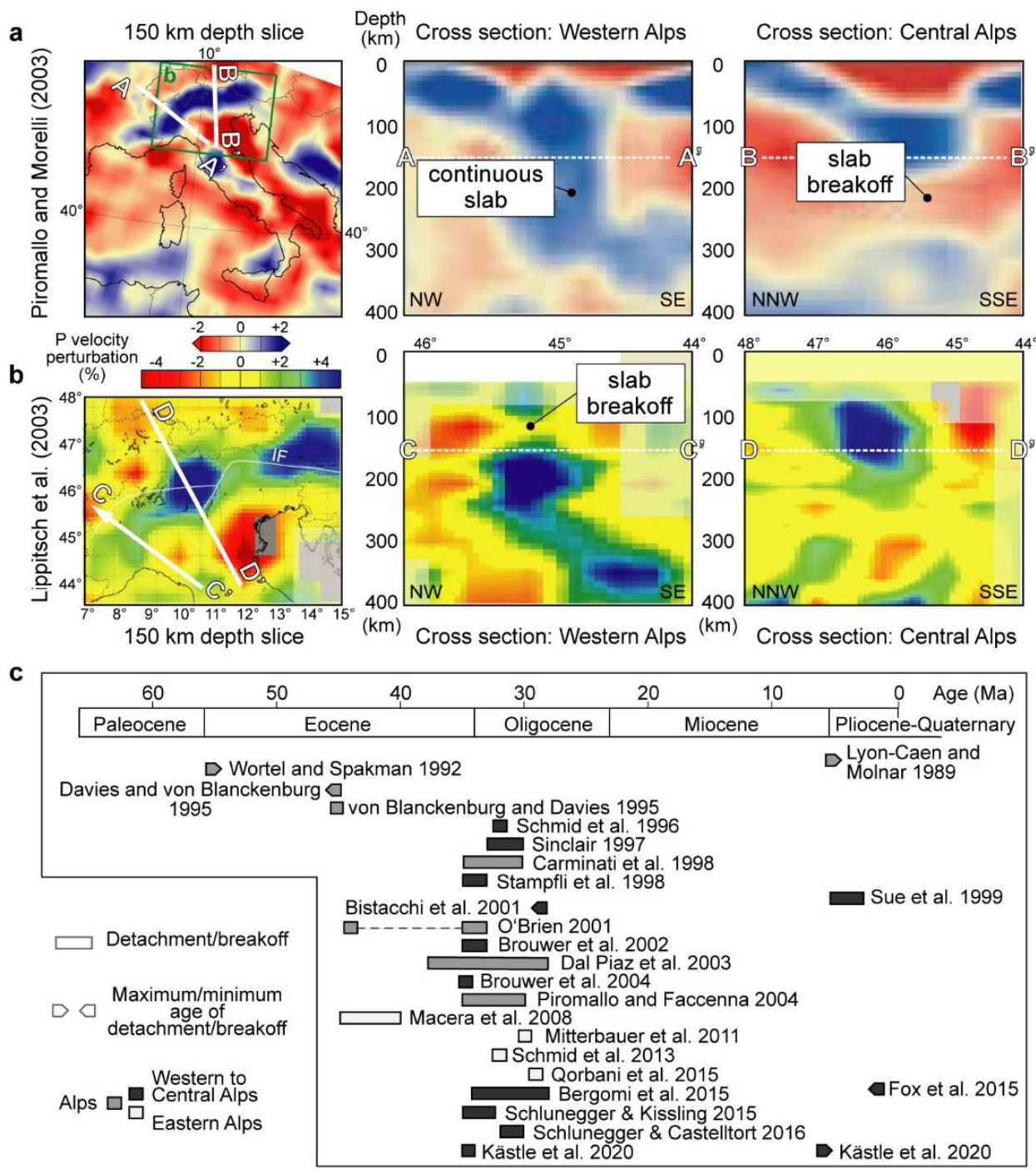

Figure 3. Slab breakoffs beneath the Alps as proposed by previous work. a: Teleseismic P-wave tomography model by Piromallo and Morelli (2003), suggesting a continuous slab beneath the Western Alps (A-A') and potential slab breakoff beneath the Central Alps (B-B') (modified after Piromallo and Faccenna 2004; Malusà et al. 2015). b: Teleseismic P-wave tomography model by Lippitsch et al. (2003), suggesting shallow slab breakoff beneath the Western Alps (C-C') and a more continuous slab beneath the Central Alps possibly affected by a deeper slab breakoff (D-D') (modified after Schmid et al. 2004); IF, Insubric Fault. c: Different ages and sites of slab breakoff/detachment events envisaged in publications on the Alpine region since the late 1980s (modified after Garzanti et al. 2018. Based on: Lyon-Caen and Molnar (1989); Wortel and Spakman (1992); Davies and von Blanckenburg (1995); von Blanckenburg and Davies (1995); Schmid et al. (1996); Sinclair (1997); Carminati et al. (1998); Stampfli et al. (1998); Sue et al. (1999); Bistacchi et al. (2001); O’Brien (2001); Brouwer et al. (2002); Dal Piaz et al. (2003); Brouwer et al. (2004); Piromallo and Faccenna (2004); Macera et al. (2008); Mitterbauer et al. (2011); Schmid et al. (2013); Bergomi et al. (2015); Fox et al. (2015); Qorbani et al. (2015); Schlunegger and Kissling (2015); Schlunegger and Castelltort (2016); Kästle et al. (2020).

This article is protected by copyright. All rights reserved. 
FIGURE 4

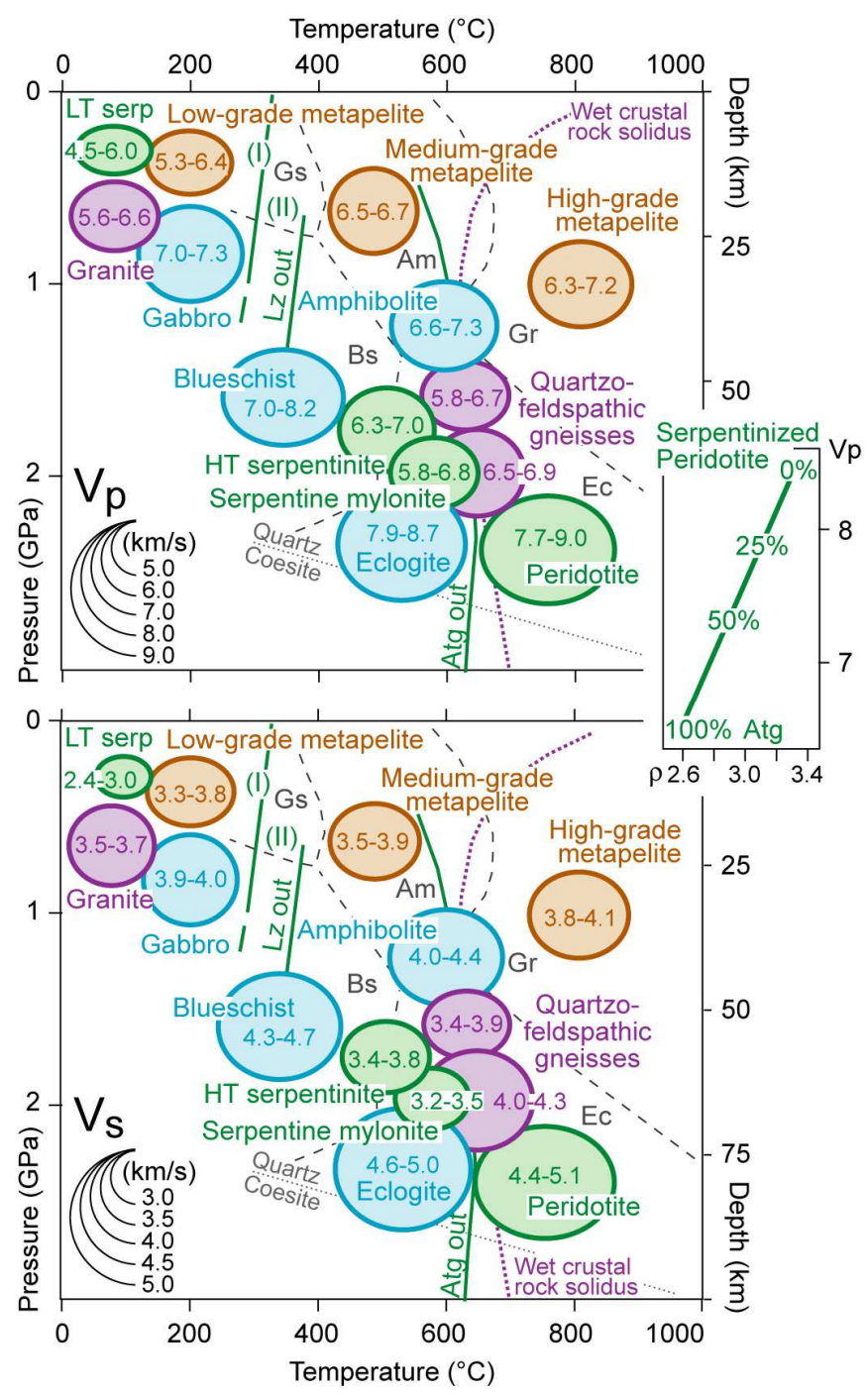

Figure 4: Measured Vp and Vs $\left(\mathrm{km} \mathrm{s}^{-1}\right)$ for different rock types possibly involved in the Alpine subduction zone $($ green $=$ ultramafic; blue $=$ mafic; purple $=$ granitic; brown $=$ pelitic $)$ at ambient conditions. The size of the ellipses is proportional to the maximum and minimum seismic velocities; ellipse location depends on the pressure-temperature range at equilibrium for each rock type. The dashed grey lines indicate the metamorphic facies boundaries (Am = Amphibolite; $\mathrm{Bs}=$ Blueschist $; \mathrm{Ec}=$ Eclogite; $\mathrm{Gr}=$ Granulite; $\mathrm{Gs}=$ Greenschist $)$. Antigorite (Atg) stability fields after Hilairet et al. (2006); lizardite (Lz) stability fields after Evans et al. (2004) (I - Onset of Lz destabilization into Atg) and Schwartz et al. (2013) (II - Maximal stability limit of Lz observed in natural serpentinites); wet crustal-rock solidus after Schmidt et al. (2004). Note the progressive increase in $\mathrm{Vp}$ and $\mathrm{Vs}$ with depth and metamorphic grade in pelitic, granitic and mafic rocks, and the sharp change in Vp and Vs across the Atg-out curve in ultramafic rocks. Vp variations for partially serpentinized peridotite at depths greater than $15-20 \mathrm{~km}$, where Atg is stable, are shown on the right (after Reynard, 2013). Data sources: LT and HT serpentinite after Ji et al. (2013) (the Vs lower bound for antigorite serpentinite is calculated from single-crystal elastic data, and is

This article is protected by copyright. All rights reserved. 
referred to Reuss approximation and $2 \mathrm{GPa}$, Bezacier et al., 2013); HT serpentine mylonite after Watanabe et al. (2011); peridotite after Khazanehdari et al. (2000) and Pera et al. (2003), as compiled by Bezacier et al. (2010); gabbro, blueschist and eclogite after Bezacier et al. (2010); amphibolite after Brownlee et al. (2011); granite after Rudnick and Fountain (1995) and Khazanehdari et al. (2000); quartzo-feldspathic gneiss after Kern et al. (2002) and Brownlee et al. (2011) (the Vp and Vs ranges of 6.5-6.9 and 4.0-4.3 $\mathrm{km} \mathrm{s}^{-1}$ are based on calculations for modeled rocks at $700^{\circ} \mathrm{C}$ and $2 \mathrm{GPa}$ ); low-grade metapelite after Ji et al. (2015); medium-grade metapelite (kinzigite) after Khazanehdari et al. (2000); high-grade metapelite after Weiss et al. (1999) and (stronalite) Khazanehdari et al. (2000).

This article is protected by copyright. All rights reserved. 


\section{FIGURE 5}

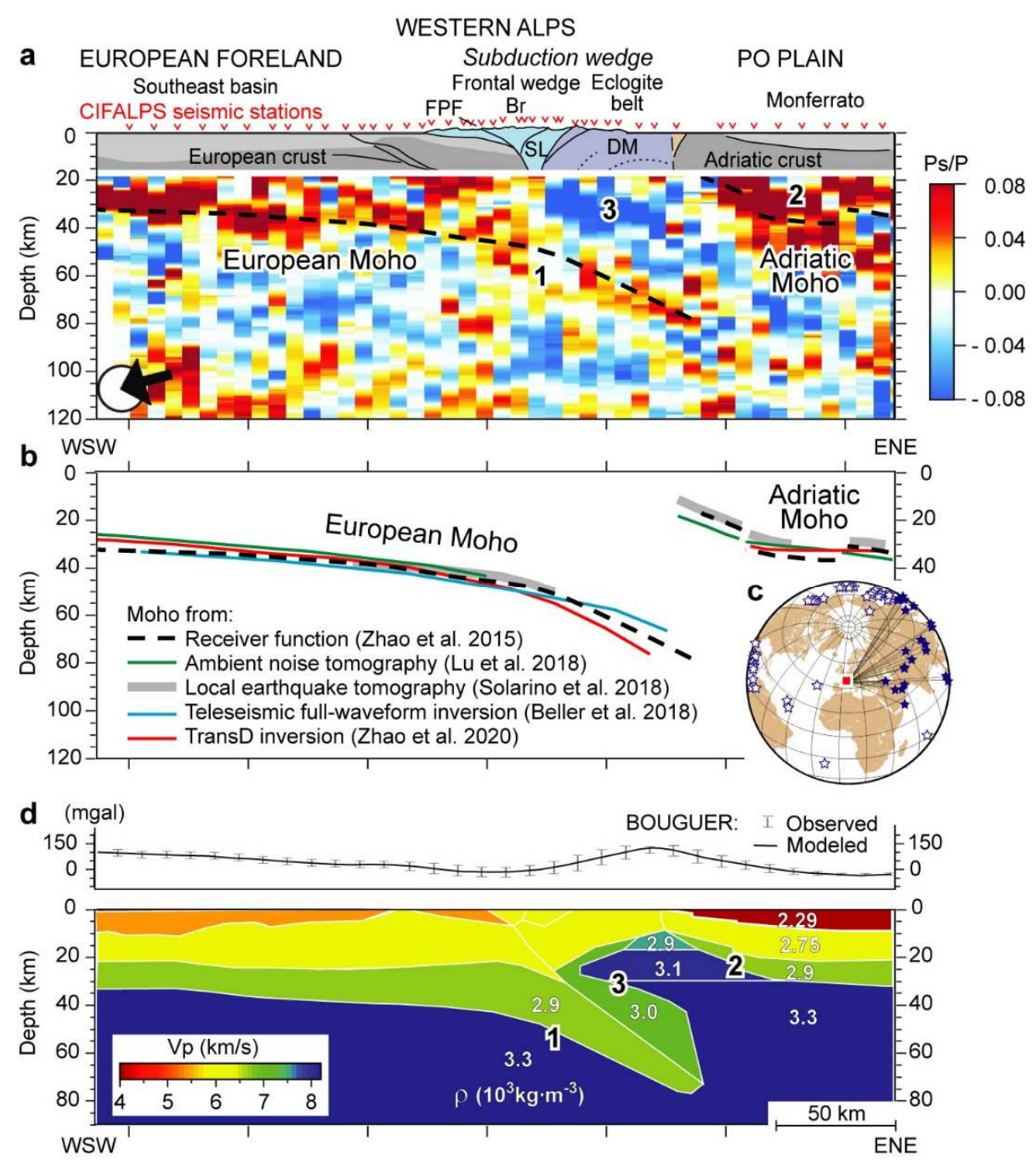

Figure 5. Moho imaging by receiver function (RF) analysis. a: Raw migrated CCP (common conversion point) depth section without horizontal smoothing, using receiver functions corresponding to ENE back-azimuths $\left(28^{\circ}-118^{\circ}\right.$, black arrow on the bottom-left) (after Zhao et al. 2015), and inferred Moho depth (dashed black lines). The European Moho (1) is continuously marked by Ps-conversions with positive polarity (red to yellow colors), dipping towards the east from $\sim 40 \mathrm{~km}$ depth beneath the Frontal Pennine Fault (FPF) to $\sim 75 \mathrm{~km}$ depth beneath the westernmost Po Plain (note the progressive weakening, from red to yellow colors, of this converted phase beneath the Alpine subduction wedge). The Adriatic Moho (2) is marked by shallower positive-polarity Ps-conversions from 10-15 km depth to the west to $20-30 \mathrm{~km}$ depth to the east. The negative polarity conversions beneath the Dora-Maira (3, in blue) mark a downward velocity decrease at 20-40 km depth. Acronyms as in Fig. 1. b: Comparison with Moho depths as later constrained by other geophysical methods: ambient noise tomography - Lu et al. 2018; local earthquake tomography - Solarino et al. 2018 (see Fig. 6); teleseismic full-waveform inversion Beller et al. 2018; transdimensional inversion of Rayleigh wave dispersion data - Zhao et al. 2020

This article is protected by copyright. All rights reserved. 
(see Fig. 7). Note the good consistency of the results despite the different techniques and datasets used. c: Locations of teleseismic events used in RF analysis (the blue stars mark events with ENE back-azimuths considered for image (a)). d: Velocity and gravity model of the CIFALPS cross section (density values in white) utilized by Zhao et al. (2015) to test the interpretation of the CCP section that fits the Bouguer anomaly data.

This article is protected by copyright. All rights reserved. 


\section{FIGURE 6}

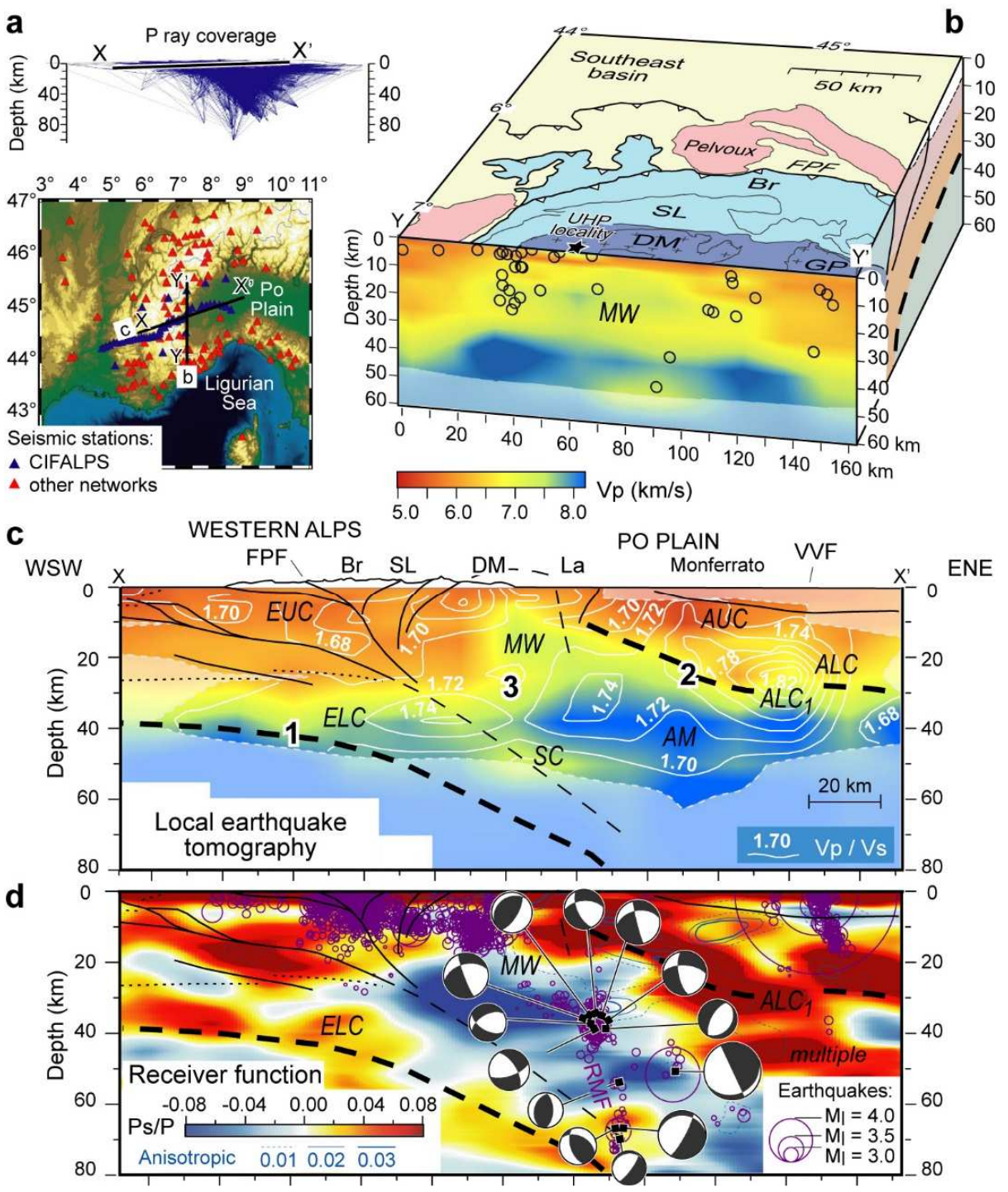

Figure 6. Crustal and mantle-wedge P velocity structure by local earthquake tomography (LET) (after Solarino et al. 2018). a: P ray coverage and location of stations used for LET. b: Absolute Vp along a N-S tomographic cross section across the Dora-Maira UHP locality (black star). Note the high-velocity body interpreted as serpentinized mantle wedge (MW); the black circles are projected hypocentres located within $\pm 3 \mathrm{~km}$ distance off the profile (masked areas have resolution diagonal elements $<0.1)$. c: WSW-ENE tomographic cross section along the CIFALPS transect (white lines are isolines of equal $\mathrm{Vp} / \mathrm{Vs}$ ). The black lines indicate tectonic features previously inferred from receiver function (RF) analysis and already indicated in Fig. 5a. Acronyms in italics indicate regions of the model discussed in the main text: $\mathrm{ALC}$ and $\mathrm{ALC}_{1}$, Adriatic lower crust; AM, Adriatic mantle; AUC, Adriatic upper crust; ELC, European lower crust; EUC, European upper crust; MW, serpentinized mantle wedge. d: Smoothed RF cross section for the same transect shown in (c), also including the amplitude of RF anisotropic component from azimuthal harmonic decomposition (blue contours, Piana Agostinetti et al. 2017), earthquakes (in purple) plotted from

This article is protected by copyright. All rights reserved. 
$\pm 20 \mathrm{~km}$ distance off the profile, and focal solutions for events deeper than $30 \mathrm{~km}$ (beach balls in grey, after Malusà et al. 2017). Note the consistency between structures imaged by the analysis of local (c) and teleseismic (d) events. RMF, Rivoli-Marene Deep Fault. Other acronyms as in Fig. 1.

This article is protected by copyright. All rights reserved. 
FIGURE 7
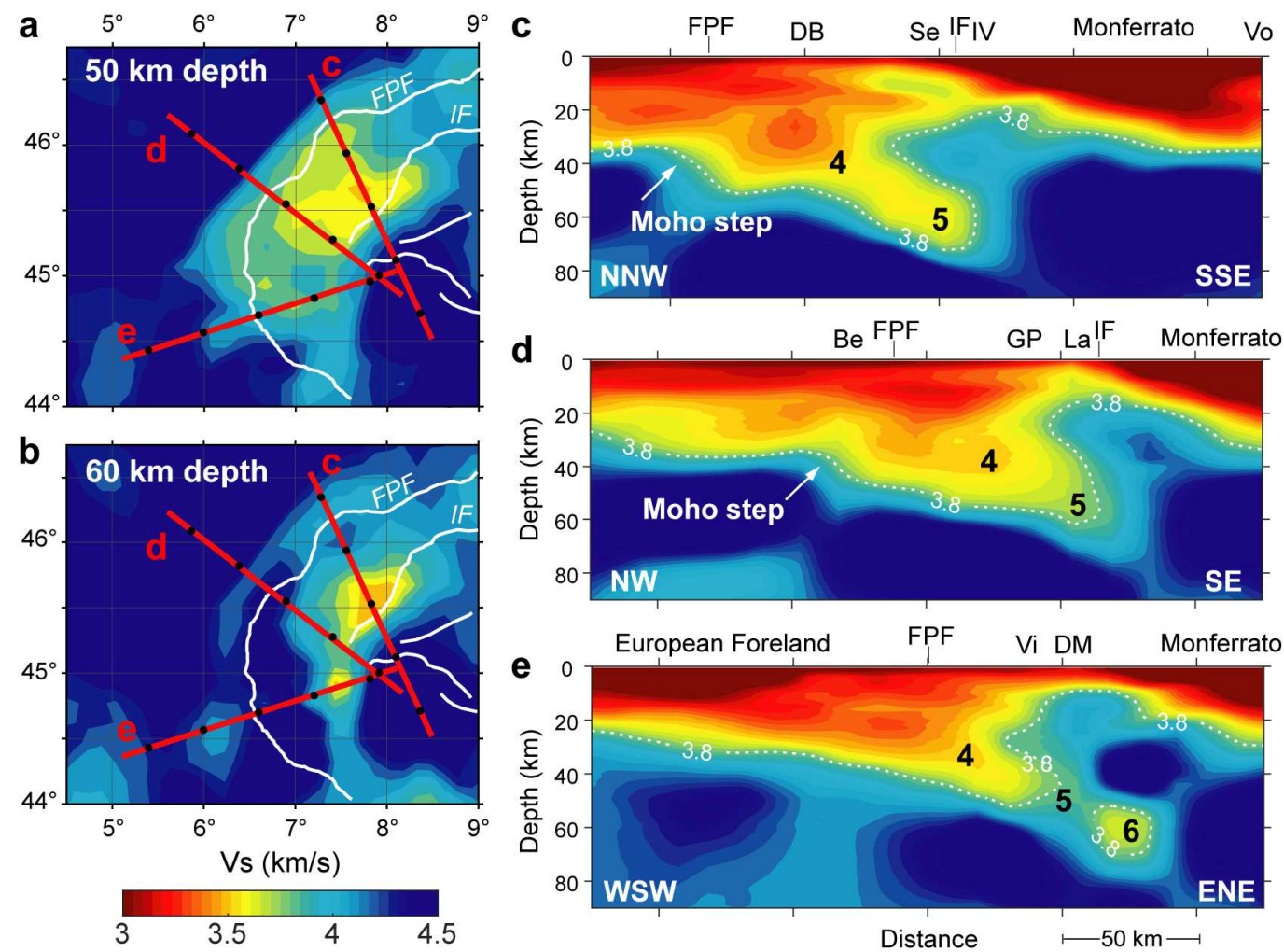

Figure 7: $S$ velocity structure of the crust and the mantle wedge as revealed by Bayesian transdimensional (TransD) inversion of Rayleigh wave dispersion data (after Zhao et al. 2020). ab: Depth slices of the Vs tomography model at 50 and $60 \mathrm{~km}$ depth. c-e: Inversion results showing absolute Vs in the 0-90 km depth range along the NFP-20 West (c), ECORS-CROP (d) and CIFALPS (e) cross-sections. The white dashed isovelocity lines indicate Vs $=3.8 \mathrm{~km} \mathrm{~s}^{-1}$. Numbers 4-to-6 indicate regions of the model discussed in the text (acronyms as in Fig. 1). The white arrow in (d) indicates a major $(\sim 8 \mathrm{~km})$ Moho step beneath the western front of the Belledonne massif (Be), first highlighted by Lu et al. (2018). A similar Moho step is observed in (c) in correspondence with the Frontal Pennine Fault (FPF). Note the sharp Vs decrease at $\sim 60 \mathrm{~km}$ depth along crosssection (e), which is not observed along cross-sections (c) and (d).

This article is protected by copyright. All rights reserved. 
FIGURE 8
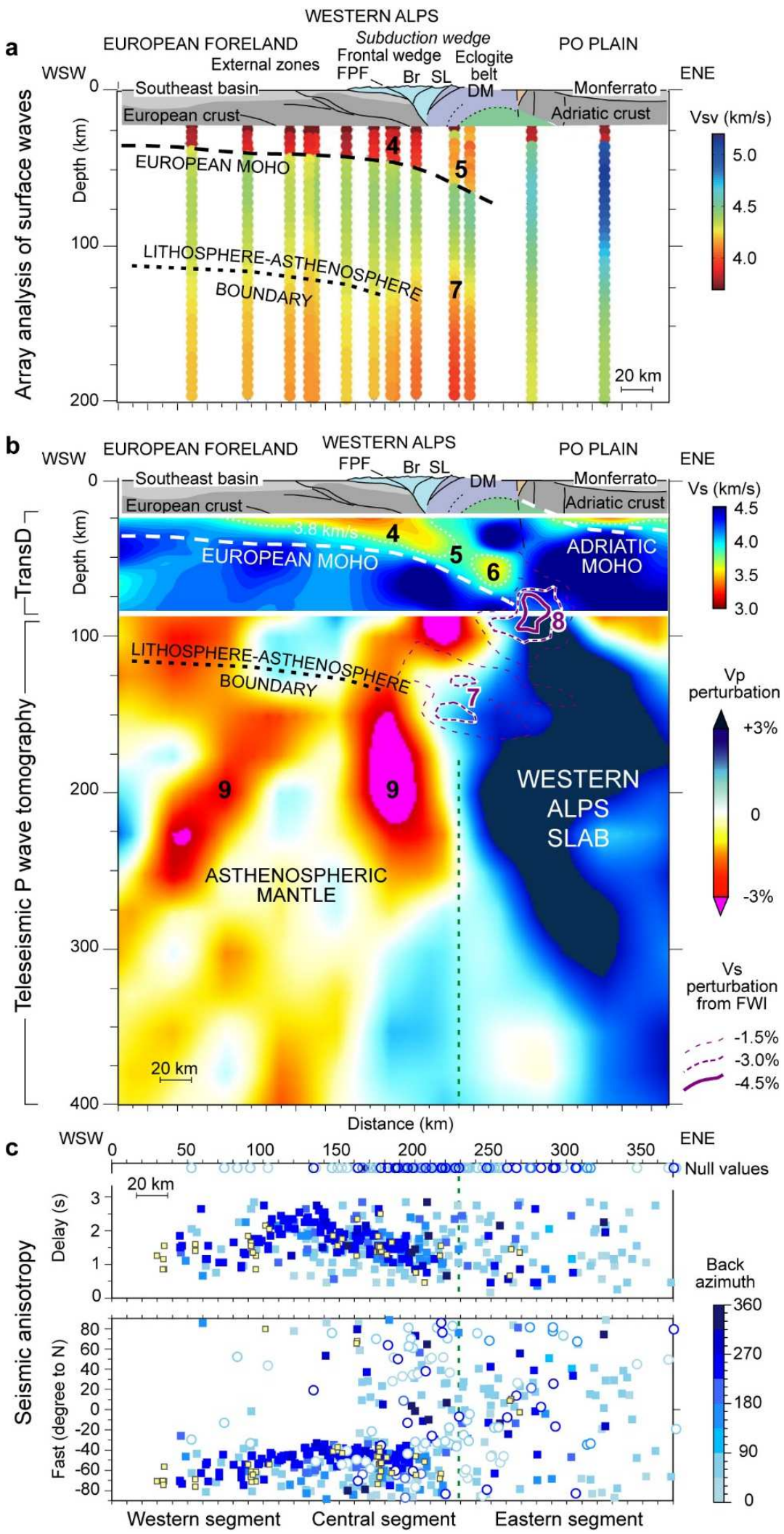

This article is protected by copyright. All rights reserved. 
Figure 8. Upper mantle velocity structure along the CIFALPS transect. a: Absolute Vs based on array analysis of seismic surface waves (after Lyu et al. 2017); numbers in bold indicate regions of the model discussed in the main text. Acronyms as in Fig. 1. b: Composite cross section showing, in the upper panel (20-90 km depth), the absolute Vs values (in $\mathrm{km} \mathrm{s}^{-1}$ ) based on Bayesian TransD inversion of surface-wave dispersion data (Zhao et al. 2020) and, in the lower panel (90$400 \mathrm{~km}$ depth), the Vp perturbations (in \%) based on teleseismic P-wave tomography (Zhao et al. 2016b); lithosphere-asthenosphere boundary as in (a). Purple lines are isolines of equal Vs anomaly (relative to the preliminary reference Earth model of Dziewonski and Anderson, 1981) as derived from teleseismic full-waveform inversion (FWI, Beller et al. 2018). Numbers 4-to-9 indicate regions of the model discussed in the main text. All of the anomalies discussed in the original publications are indicated. The European lithosphere in the upper panel is directly connected with the steeply dipping Western Alps slab (in blue) in the lower panel. A prominent low-velocity anomaly (yellow to red colors in the lower panel) is located to the west of the Western Alps slab, beneath the core of the Western Alps and the European foreland. c: Distribution of delay times and fast axis orientations of SKS splitting measured in a $60-\mathrm{km}$ wide swath profile along the CIFALPS transect. In blue are splitting measurements from Salimbeni et al. (2018) (color coded according to the back-azimuth), in yellow are splitting measurements pre-dating the CIFALPS experiment (from Barruol et al. 2004, 2011; Salimbeni et al. 2008, 2013). Null measurements (empty circles) are plotted as fast axes parallel to the back-azimuth and dt $>3 \mathrm{~s}$. Note the sharp change in fast axis orientation and delay time across the dashed green line, which reflects a major change in upper mantle structure as shown in (b). In the western and central segments of the CIFALPS profile, delay times are lower in correspondence of stronger low-Vp perturbations.

This article is protected by copyright. All rights reserved. 


\section{FIGURE 9}
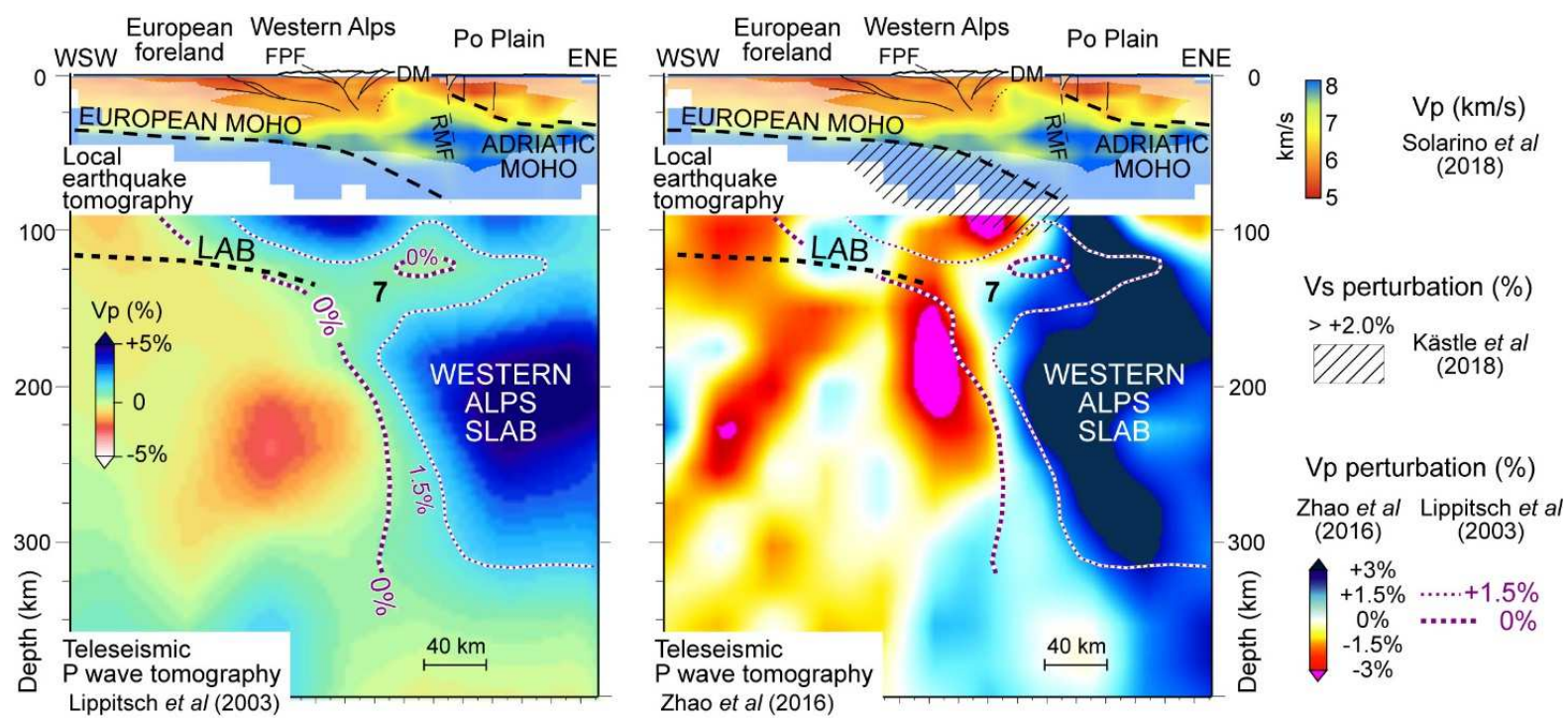

Figure 9: Comparison of upper mantle Vp perturbations beneath the CIFALPS transect according to the teleseismic P-wave tomography models of Lippitsch et al. (2003) (left) and Zhao et al. (2016b) (right). Absolute Vp values in the 0-60 km depth range are from Solarino et al. (2018) (see Fig. 6). Note the good correspondence between the high velocity anomaly detected by Zhao et al. (2016b) (in blue on the panel to the right) and the first-order features of the Lippitsch et al. (2003) model as highlighted by isolines of equal Vp anomaly (in purple, also reported in the panel to the right for the sake of clarity). Despite the broadly similar velocity structures, either a continuous or broken-off slab was proposed (see text for discussion). The region of positive Vs perturbation $(>+2 \%$ relative to the preliminary reference Earth model of Dziewonski and Anderson, 1981) proposed by Kästle et al. (2018) is also reported (black hatched area to the right). Acronyms: DM, Dora-Maira; FPF, Frontal Pennine Fault; LAB, lithosphere-asthenosphere boundary; RMF, Rivoli-Marene Deep Fault.

This article is protected by copyright. All rights reserved. 
FIGURE 10

CA, Central Alps

DI, Dinarides

EA, Eastern Alps

NA, Northern Apennines

$\mathrm{SA}$, Southern Apennines

WA, Western Alps

a

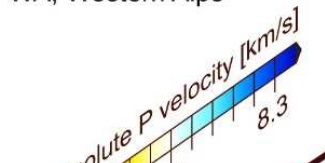

$\square$ focation of events utilize

- Location of events

utilized for teleseismic $\mathrm{P}$ wave tomography

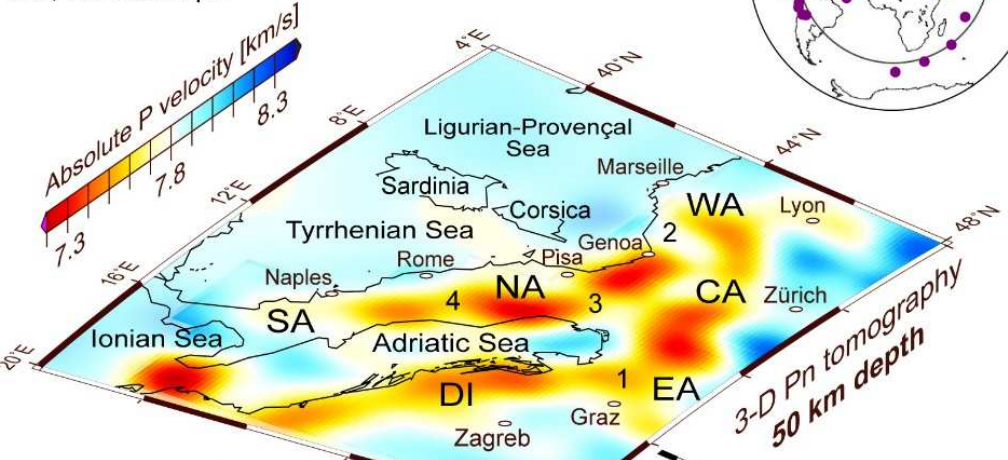

b

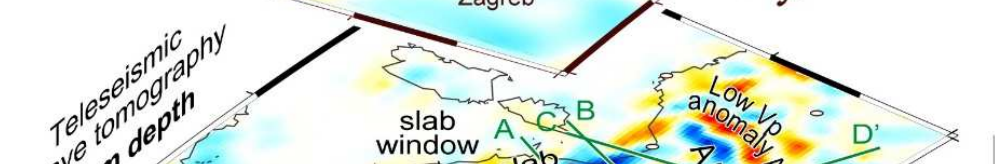

c
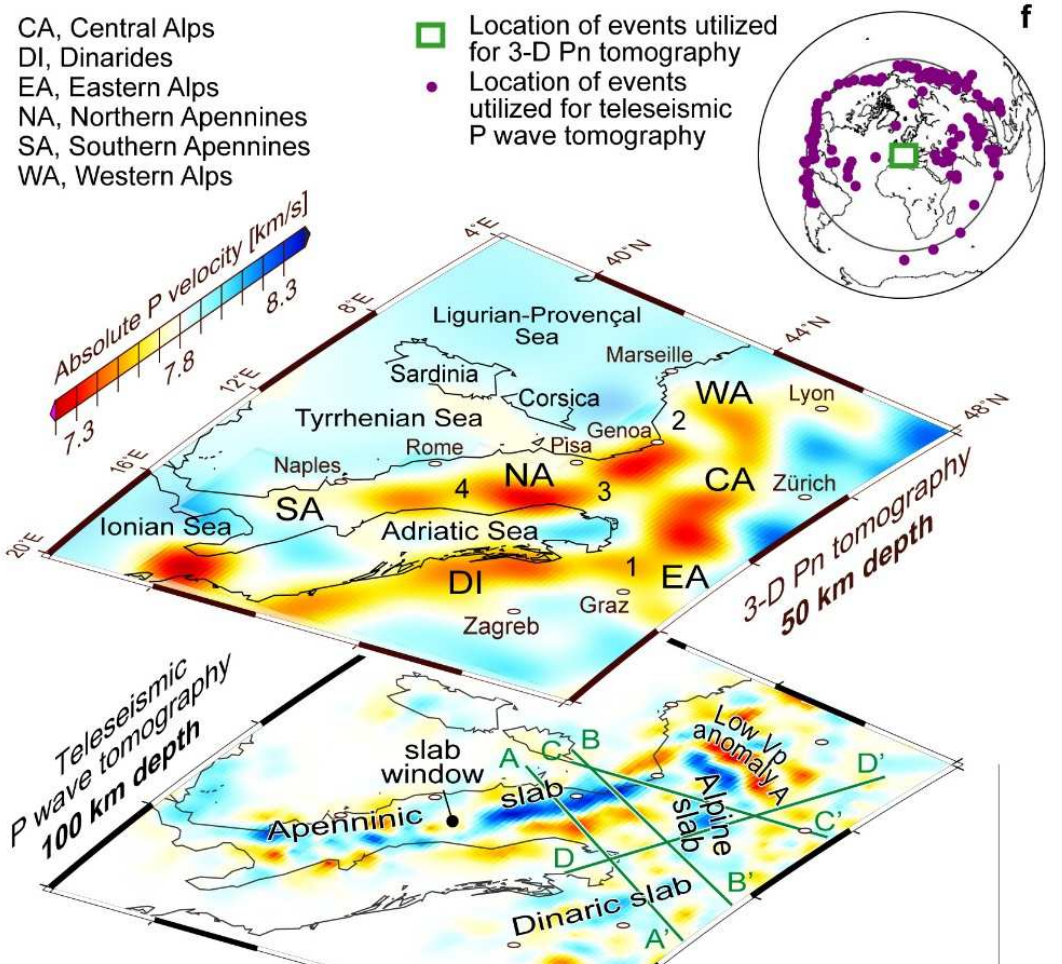

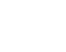


Figure 10. Upper mantle velocity structure in the broader Alpine region. a: Absolute $\mathrm{P}$ velocities at $50 \mathrm{~km}$ depth according to the 3-D Pn tomography model of Sun et al. (2019). Belts of yellowto-orange colors indicate the lateral extent of continental subduction (numbers 1 to 4 indicate features discussed in the main text). b-d: Vp anomalies in the teleseismic tomography model of Zhao et al. (2016b) at 100, 200 and 300-km depth. Low-velocity anomalies (A and B, yellow-tored colors) are detected on both sides of the Alpine slab, which is underlined by a laterally continuous high-velocity anomaly (blue colors). e: Representative cross sections (see locations in (b) - green solid lines) of the teleseismic tomography model of Zhao et al. (2016b), showing the attitude of the Alpine, Apenninic and Dinaric slabs. f: Seismic events used for the tomography models of Sun et al. (2019) (green box) and Zhao et al. (2016b) (purple dots).

This article is protected by copyright. All rights reserved. 


\section{FIGURE 11}

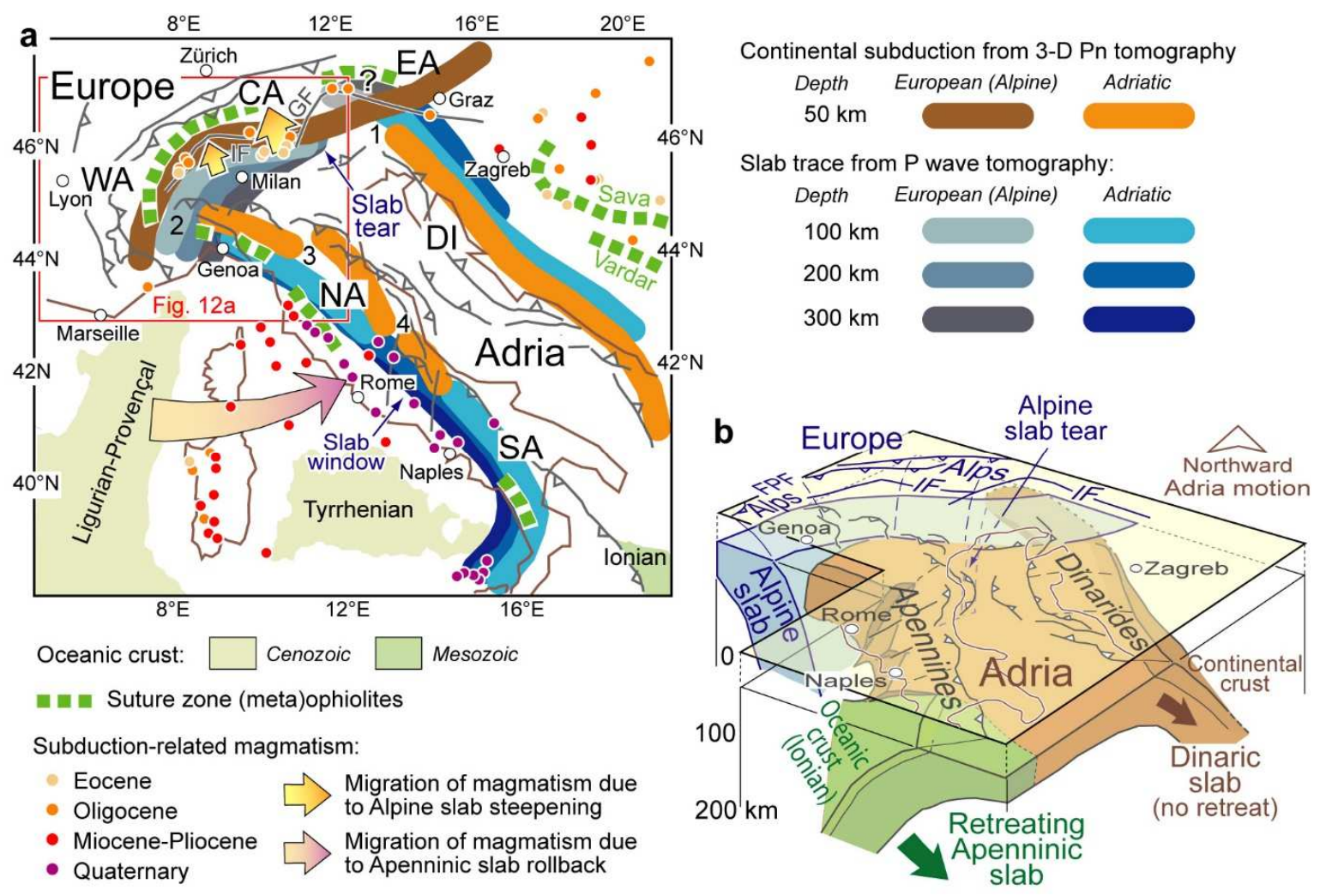

Figure 11. Interpretive slab structure beneath the Alpine region as constrained by recent tomography studies. a: Tectonic sketch map showing the relations among slab structure (Sun et al. 2019), distribution of orogenic magmatism (Carminati and Doglioni 2012; Ji et al. 2019; Kovacs et al. 2007) and accreted (meta)ophiolites (Bigi et al. 1990; Ustaszewski et al. 2008). The present-day slab traces at 100, 200 and 300-km depth are based on the P-wave tomography models of Zhao et al. (2016b) and Piromallo and Morelli (2003) (which was only considered outside of the well-resolved areas of the Zhao et al. (2016b)'s model). Numbers 1 to 4 (same as in Fig. 10a) indicate features discussed in the main text. The question mark indicates the controversial highvelocity anomaly beneath the remnants of the former Alpine subduction zone. IF, Insubric Fault; GF, Giudicarie Fault; other acronyms as in Fig. 10a. b: Cartoon summarizing the relationships between the Alpine slab and the Apenninic and Dinaric slabs (modified after Sun et al. 2019).

This article is protected by copyright. All rights reserved. 
a SHEAR WAVE SPLITTING MEASUREMENTS

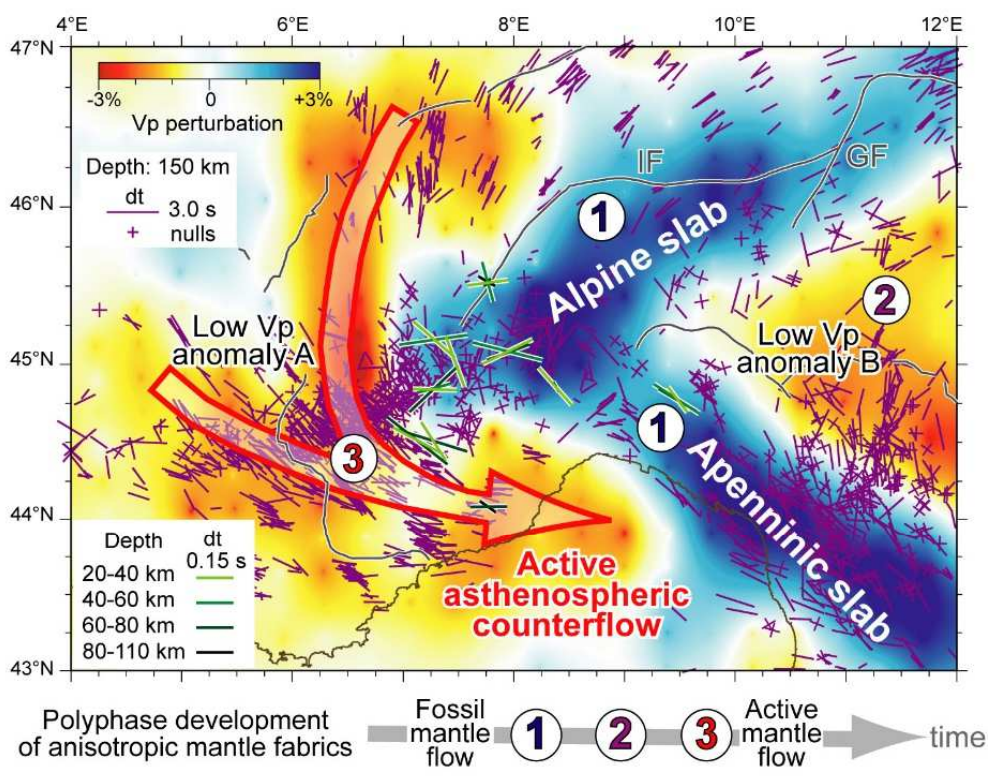

\section{b FABRIC INHERITED FROM TETHYAN RIFTING 1}

Fabric development during mantle exhumation

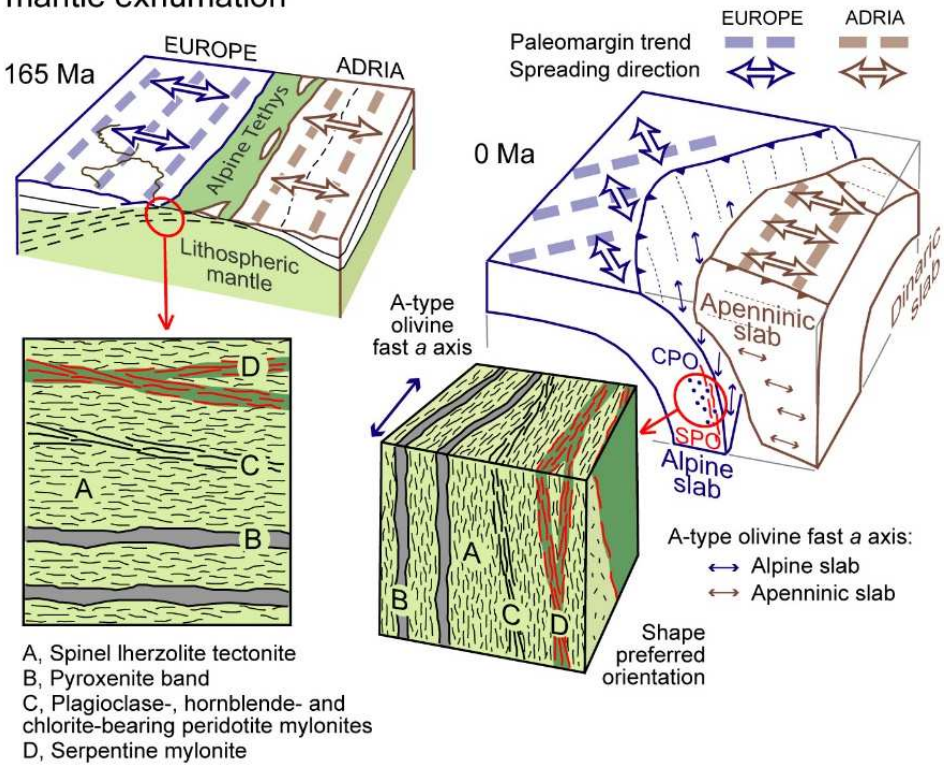

C FABRIC DEVELOPMENT DURING NORTHWARD ADRIA MOTION
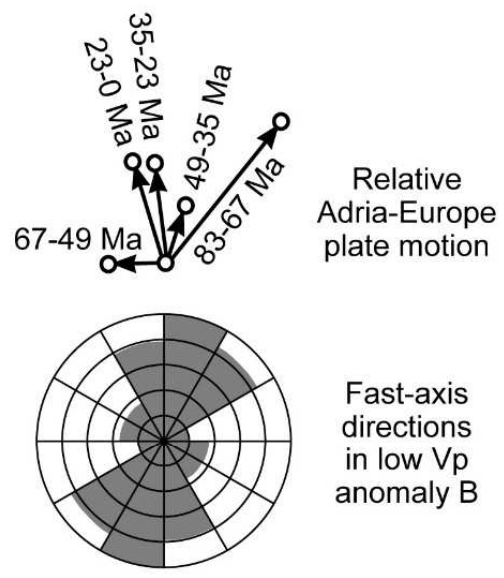

Fast-axis directions in low $\mathrm{Vp}$ anomaly B

\section{d ACTIVE MANTLE FLOW}
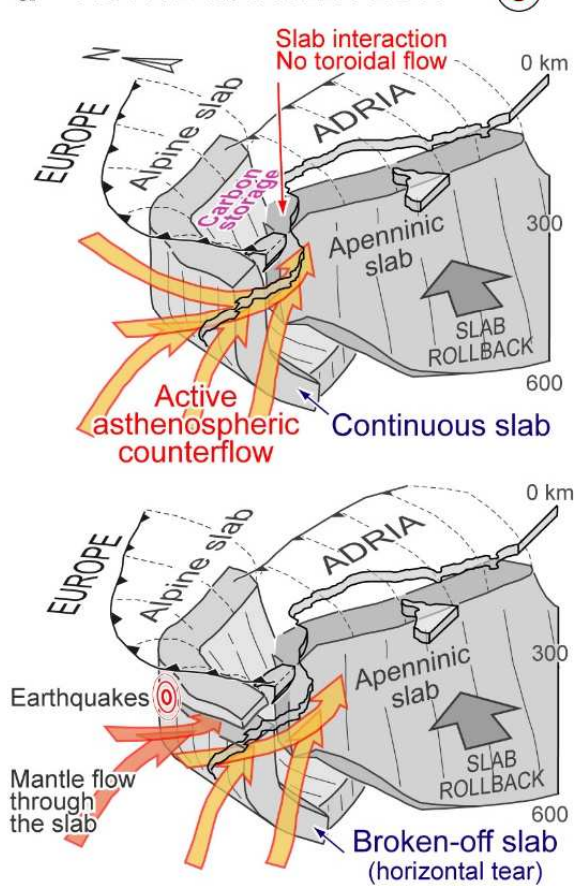

Figure 12. Polyphase development of anisotropic mantle fabrics in the Alpine region. a: Map of single SKS splitting measurements (in purple) (Barruol et al. 2004, 2011; Salimbeni et al. 2008, 2013, 2018) and S-wave anisotropy measurements from local earthquakes (in green) (Baccheschi et al. 2019). Measurements are plotted on the 150-km depth slice of the tomography model of Zhao et al. (2016b) (GF, Giudicarie Fault; IF, Insubric Fault). Segments are parallel to the fast-velocity axis and scaled with delay time (note the different scales for SKS and S waves). Numbers 1 to 3 indicate different anisotropic fabrics as described in (b) to (d): fabric 1 is found in correspondence

This article is protected by copyright. All rights reserved. 
with the high $\mathrm{Vp}$ anomalies marking the Alpine and Apenninic slabs; fabrics 2 and 3 are from low $\mathrm{Vp}$ anomalies B and A, respectively. No toroidal mantle flow is observed around the northern tip of the Apenninic slab. b: Anisotropic mantle fabric 1 inherited from Tethyan rifting. To the left, as observed in outcrops of exhumed mantle rocks within the Alpine orogenic wedge (e.g., ErroTobbio unit). To the right, expected attitude of fabric 1 in the Alpine and Apenninic slabs, based on the direction of plate spreading, trench orientation (Malusà et al. 2015, 2016b) and slab dip. $\mathrm{CPO}=$ crystallographic preferred orientation; $\mathrm{SPO}=$ shape preferred orientation. $\mathbf{c}$ : Fast-axis directions of anisotropic mantle fabric 2 as compared to the direction of relative Adria-Europe plate motion (Dewey et al. 1989; arrows are scaled with distance; numbers indicate the age in Ma). d: Alternative slab structures beneath the Alpine region (i.e., continuous vs. broken-off Alpine slab) and expected patterns of active asthenospheric mantle flows resulting from Apenninic slab rollback (fabric 3). Slab breakoff beneath the Western Alps (e.g. Kästle et al., 2020) would imply mantle flow through the slab and anomalously deep earthquakes beneath the northern Po Plain, unlike observed. Note the different origin of the low $\mathrm{Vp}$ anomaly A (explained by a vertical component of active asthenospheric counterflow by Salimbeni et al. 2018) and the low Vp anomaly $\mathrm{B}$ (explained by the presence of carbon-rich melts released from the Alpine slab by Malusà et al. 2018).

This article is protected by copyright. All rights reserved. 
FIGURE 13

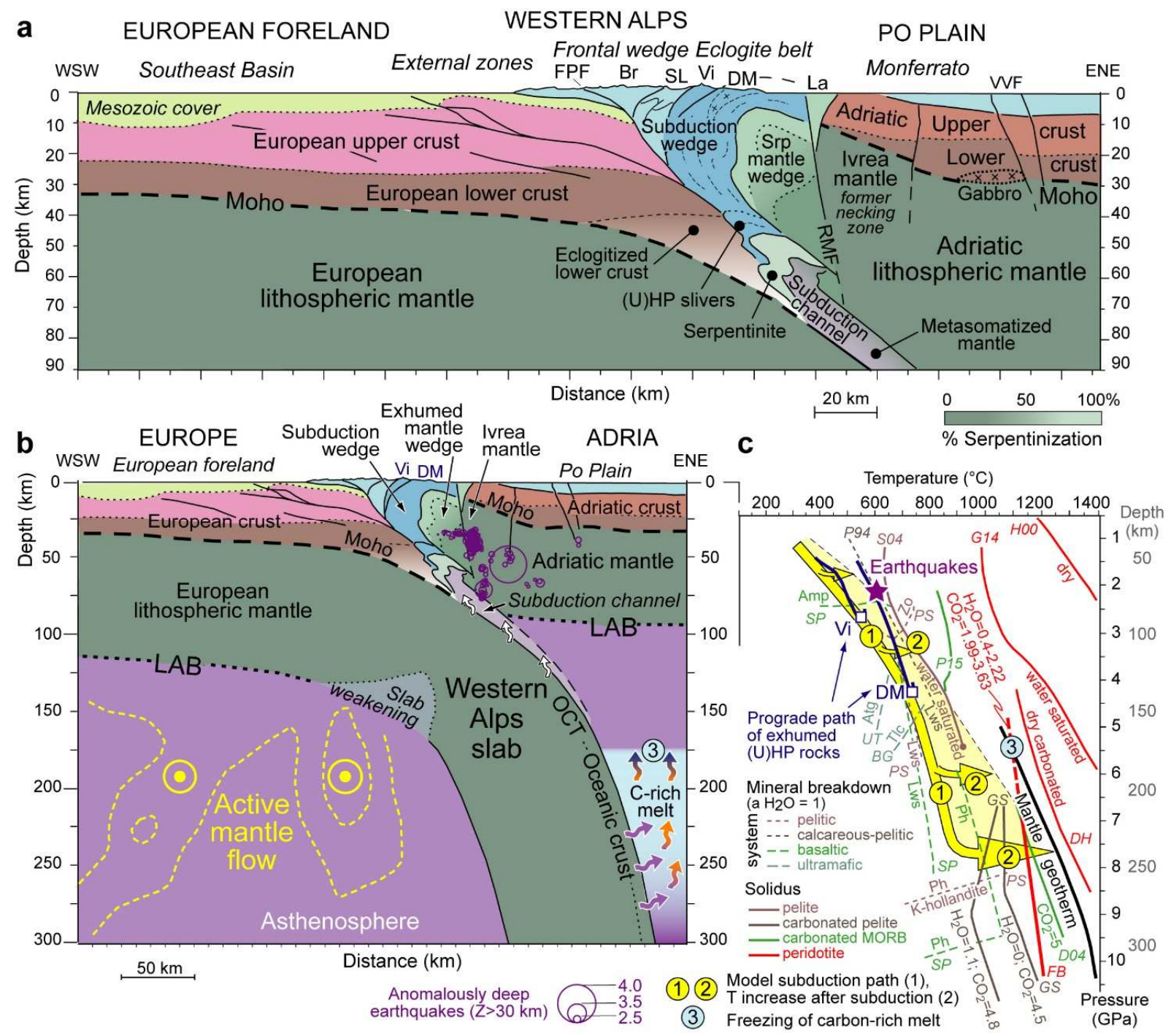

Figure 13. Geologic cross sections based on geophysical constraints along the CIFALPS transect (Beller et al. 2018; Lyu et al., 2017; Malusà et al. 2017; Salimbeni et al. 2018; Solarino et al. 2018; Zhao et al. 2015, 2016b, 2020). a: Lithospheric-scale cross section showing the serpentinized mantle wedge beneath the Dora-Maira (U)HP dome (DM) (Solarino et al. 2018) and the slivers of serpentinite and (U)HP rocks exhumed along the subduction channel (Zhao et al. 2020) (the amount of serpentinization is inferred from seismic velocities, see Fig. 4). The Ivrea mantle, representing the former necking zone of the southern Tethyan margin, is juxtaposed against serpentinized mantle-wedge rocks along the Rivoli-Marene deep Fault (RMF). Other acronyms: Br, Briançonnais; FPF, Frontal Pennine Fault; LA, Lanzo; SL, Schistes lustrés; Vi, Viso; VVF, Villalvernia-Varzi Fault. b: Cross section at upper-mantle scale. Active mantle flow beneath the European foreland, likely triggered by Apenninic slab rollback (Salimbeni et al. 2018), promote thermal weakening of the overlying Alpine slab, which is unbroken (Zhao et al. 2016b). Carbonrich melt released from the Alpine slab may determine supersolidus conditions in the overlying mantle-wedge peridotite, and the resulting network of carbonate-silicate melt is solidified at $\sim 180$

This article is protected by copyright. All rights reserved. 
km depth (Malusà et al. 2018). White arrows indicate potential fluid flow in the subduction channel. Anomalously deep earthquakes with hypocentral depth $>30 \mathrm{~km}$ (in purple) mainly originate in the Adriatic lithospheric mantle. Acronyms: OCT, ocean-continent transition; LAB, lithosphere-asthenosphere boundary (after Lyu et al. 2017; Malusà et al. 2018). c: Subduction paths in the southern Western Alps and associated mineral reactions (modified after Malusà et al. 2018); depth (y-axis) as in (b); DM, Dora-Maira; Vi, Viso. Cold subduction (yellow path 1, after Syracuse et al. 2010) favours the preservation of carbonates and hydrous minerals to asthenospheric depths. The temperature increase after subduction cessation (2) is consistent with the occurrence of anomalously deep earthquakes in peridotites of the Adriatic upper plate (purple star). Increasing temperatures induce: (i) dehydration reactions with fluids possibly rising along the subduction channel; and (ii) melting of metasediments and carbonated metabasics, with carbon-rich melts that determine supersolidus conditions in the mantle-wedge peridotite, at depth greater than $180 \mathrm{~km}$ (freezing point 3). Keys to solidus curves (continuous lines): in brown, wet solidus and second critical end-point of pelite (S04, Schmidt et al. 2004); in grey, carbonated pelite solidi with bulk $\mathrm{H}_{2} \mathrm{O}$ and $\mathrm{CO}_{2}$ contents in wt\% (GS, Grassi and Schmidt 2011); in green, part of the solidus of carbonated basaltic eclogite (D04, Dasgupta et al. 2004) and hydrated and carbonated gabbro (P15, Poli, 2015); in red, solidi of dry peridotite (H00, Hirschmann 2000), water saturated peridotite (G14, Green et al. 2014), dry carbonated peridotite (DH, Dasgupta and Hirschmann 2006) and potassium-rich hydrated carbonated peridotite (FB, as compiled by Grassi and Schmidt 2011). Keys to mineral breakdown curves (dashed lines): parts of amphibole-, zoisite-, lawsoniteand phengite-out curves in basalts (SP, Schmidt and Poli 1998) and pelites/greywakes (PS, Poli and Schmidt, 2002), part of the lawsonite-out curve in a CASH system (P94, Pawley 1994); part of antigorite- and talc-out curves in ultramafic system (UT, Ulmer and Trommsdorff 1999; BG, Bose and Ganguly 1995).

This article is protected by copyright. All rights reserved. 
FIGURE 14

\section{a}

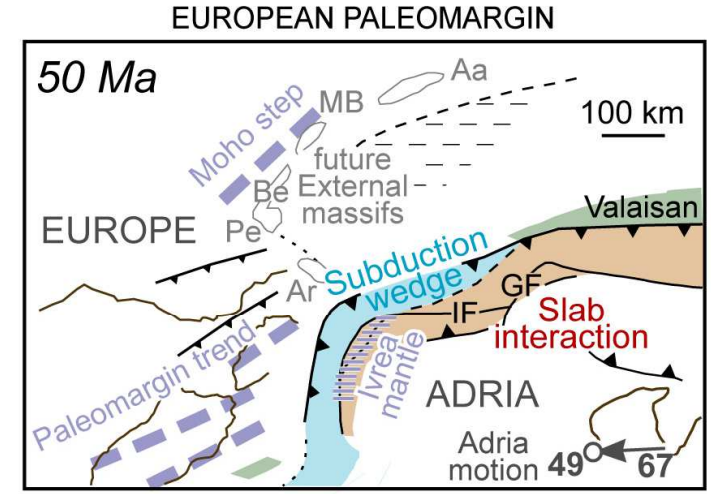

C ALPINE-APENNINIC SLAB INTERACTION ONSET OF SLAB ROLLBACK

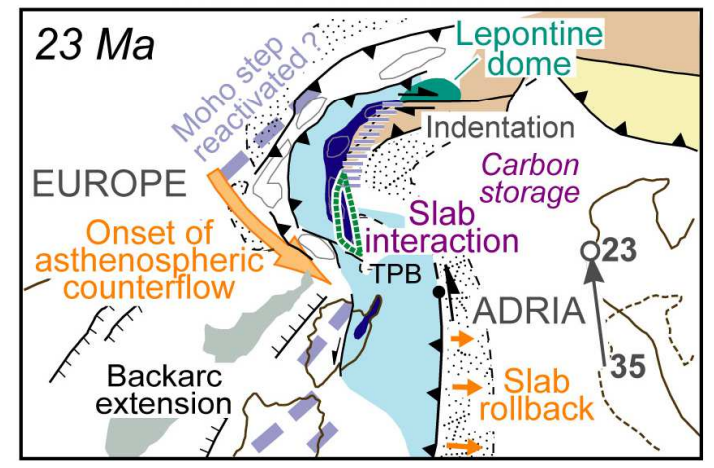

b LOCALIZED PLATE DIVERGENCE (U)HP ROCK AND MANTLE WEDGE EXHUMATION
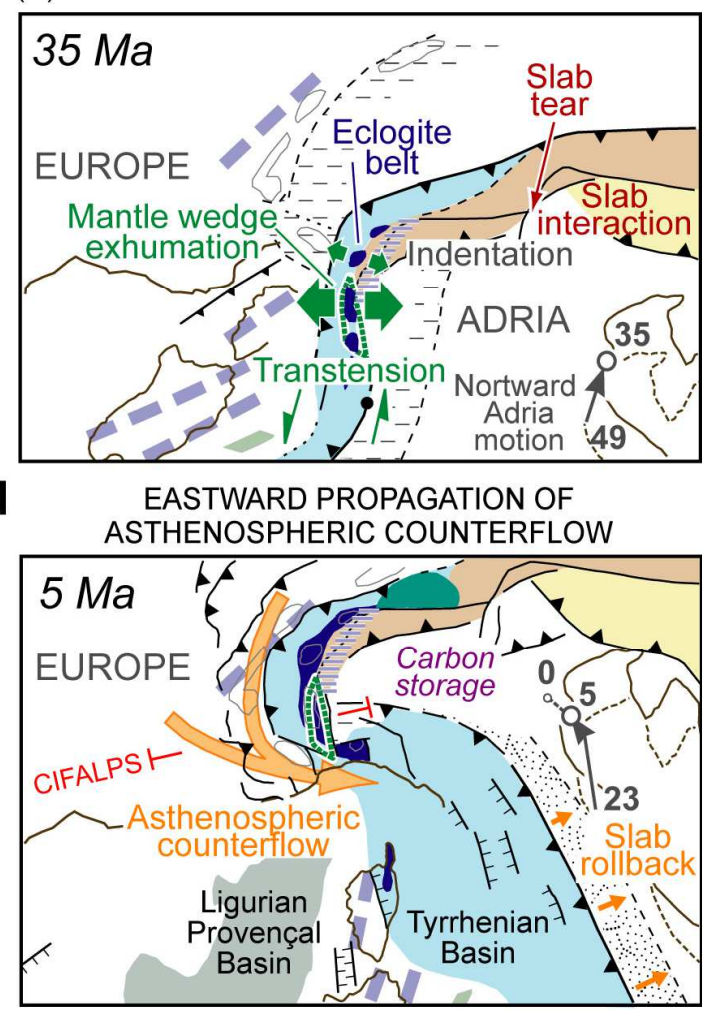

Figure 14. Cenozoic evolution of the Adria-Europe plate boundary zone in four steps (modified after Malusà et al. 2015) showing the progressive development of crustal and upper mantle structures revealed by geophysical experiments. a: $50 \mathrm{Ma}$ - Oblique subduction of the European paleomargin beneath Adria. The European plate includes a Moho step near the future External massifs (likely an inheritance of pre-Alpine tectonics); the Adriatic plate includes the Ivrea mantle (former necking zone of the southern margin of the Tethys). Subduction of Tethys ocean lithosphere is almost completed; the SE-dipping Alpine slab starts interacting with the NE-dipping Dinaric slab. b: $35 \mathrm{Ma}$ - Northward Adria motion induces tearing of the Alpine slab beneath the Eastern Alps, indentation of Adriatic lithosphere beneath the Alpine subduction wedge in the Central Alps, and transtension in the Western Alps, leading to mantle-wedge and (U)HP rock exhumation (the exhumed mantle wedge of the southern Western Alps is juxtaposed against the previously exhumed Ivrea mantle). c: $23 \mathrm{Ma}$ - Onset of Alpine-Apenninic slab interaction and Apenninic slab rollback inducing extension in the Apenninic backarc. The lack of a toroidal mantle flow around the northern tip of the Apenninic slab starts to be compensated by SE-ward directed counter flow in the asthenospheric mantle beneath the European foreland. The Moho step near the future External massifs is possibly reactivated by flexural loading. Carbon-rich melts are realeased from the Alpine slab due to progressive thermal reequilibration of the slab after subduction cessation, carbon starts to be stored in the overlying asthenospheric mantle. d: $5 \mathrm{Ma}$ - Further Apenninic slab retreat determines the E-ward propagation of the asthenospheric counterflow towards the Ligurian Alps, with consequent tilting of the Tertiary Piedmont basin (TPB) succession. Other keys as in Fig 1.

This article is protected by copyright. All rights reserved. 
Table 1. Summary table of the CIFALPS geophysical approaches and main information retrieved

\begin{tabular}{|l|l|l|}
\hline Method & Main information retrieved & Reference \\
\hline Receiver function analysis & Moho imaging beneath the subduction wedge & Zhao et al. 2015 \\
\hline $\begin{array}{l}\text { Teleseismic P-wave } \\
\text { tomography }\end{array}$ & $\begin{array}{l}\text { Upper mantle velocity structure and slab } \\
\text { configuration }\end{array}$ & Zhao et al. 2016b \\
\hline Array analysis of surface waves & $\begin{array}{l}\text { Lithosphere-asthenosphere boundary beneath } \\
\text { the European plate }\end{array}$ & Lyu et al. 2017 \\
\hline HypoDD earthquake relocation & Detection of lithospheric faults & Malusà et al. 2017 \\
\hline $\begin{array}{l}\text { Receiver function azimuthal } \\
\text { harmonic decomposition }\end{array}$ & Detection of anisotropic rocks in the lithosphere & Piana Agostinetti et al. 2017 \\
\hline $\begin{array}{l}\text { Teleseismic full-waveform } \\
\text { inversion }\end{array}$ & $\begin{array}{l}\text { Moho imaging and detection of velocity } \\
\text { anomalies in the Alpine subduction channel }\end{array}$ & Beller et al. 2018 \\
\hline Local earthquake tomography & $\begin{array}{l}\text { Moho imaging and absolute P-wave velocity } \\
\text { structure of the European and Adriatic crust, the } \\
\text { uppermost Adriatic mantle and the subduction } \\
\text { wedge }\end{array}$ & Solarino et al. 2018 \\
\hline SKS splitting measurement & $\begin{array}{l}\text { Seismic anisotropy due to lattice preferred } \\
\text { orientation of olivine crystals in the upper } \\
\text { mantle }\end{array}$ & Salimbeni et al. 2018 \\
\hline $\begin{array}{l}\text { S wave splitting of } \\
\text { intermediate-depth earthquakes }\end{array}$ & $\begin{array}{l}\text { Seismic anisotropy in the crust and lithospheric } \\
\text { mantle }\end{array}$ & Baccheschi et al. 2019 \\
\hline 3-D Pn tomography & Seismic signature of continental subduction & Sun et al. 2019 \\
\hline $\begin{array}{l}\text { TransD inversion of Rayleigh } \\
\text { wave dispersion data }\end{array}$ & $\begin{array}{l}\text { Moho imaging and absolute S wave velocity } \\
\text { structure of the European and Adriatic } \\
\text { lithosphere, the subduction wedge and the } \\
\text { subduction channel }\end{array}$ & Zhao et al. 2020 \\
\hline
\end{tabular}

This article is protected by copyright. All rights reserved. 